\title{
'Making it' through migration: success (im)mobility and 'development' in The Gambia
}

\author{
Martin J. Aucoin \\ West Virginia University, ma0234@mix.wvu.edu
}

Follow this and additional works at: https://researchrepository.wvu.edu/etd

Part of the Development Studies Commons, Human Geography Commons, and the Migration Studies Commons

\section{Recommended Citation}

Aucoin, Martin J., "'Making it' through migration: success (im)mobility and 'development' in The Gambia" (2020). Graduate Theses, Dissertations, and Problem Reports. 7771.

https://researchrepository.wvu.edu/etd/7771

This Thesis is protected by copyright and/or related rights. It has been brought to you by the The Research Repository @ WVU with permission from the rights-holder(s). You are free to use this Thesis in any way that is permitted by the copyright and related rights legislation that applies to your use. For other uses you must obtain permission from the rights-holder(s) directly, unless additional rights are indicated by a Creative Commons license in the record and/ or on the work itself. This Thesis has been accepted for inclusion in WVU Graduate Theses, Dissertations, and Problem Reports collection by an authorized administrator of The Research Repository @ WVU. For more information, please contact researchrepository@mail.wvu.edu. 
Graduate Theses, Dissertations, and Problem Reports

2020

'Making it' through migration: success (im)mobility and 'development' in The Gambia

Martin J. Aucoin

Follow this and additional works at: https://researchrepository.wvu.edu/etd

Part of the Development Studies Commons, Human Geography Commons, and the Migration Studies Commons 


\title{
'Making it' through migration: success, (im)mobility, and 'development' in The Gambia
}

\author{
Martin J. Aucoin \\ Thesis submitted to the Eberly College of Arts and Sciences \\ at West Virginia University \\ in partial fulfillment of the requirements for the degree of \\ Master of Arts in \\ Geography \\ Cynthia Gorman, Ph.D., Chair \\ Jamie Shinn, Ph.D. \\ Tamba M'bayo, Ph.D.
}

Department of Geology and Geography

Morgantown, West Virginia

2020

Keywords: migration, mobility, The Gambia, development, transnational, geography, North America

Copyright 2020 Martin Aucoin 


\begin{abstract}
'Making it' through migration: success, (im)mobility, and 'development' in The Gambia
\end{abstract}

\author{
Martin Aucoin
}

Contemporary scholarly and journalistic literature consistently represents migration from and through The Gambia using the lens of "crisis". While these representations normally focus on Gambian migration to European states - a movement that is highly politicized - this thesis presents a case study of Gambian migration to a less-politicized destination, North America, in order to explore the relationship between lived experiences and representations of migration absent the discourse of crisis that pervades other scholarly and journalistic works. Drawing on the mobilities paradigm, feminist geographies of migration, critical race theory, transnationalism, and literatures on bordering, humanitarianism and development, I examine, through a multi-sited case study, the experiences of Gambians who migrated to the U.S. and Canada, then compare them to the ways their experiences are represented in The Gambia. I then, through a discourse analysis, compare the relationship between lived experience and representation in the North American case study to the ways that Gambian migrants are portrayed by European actors in attempts to stem or stop migration flows. This thesis reveals that legal status intersects with class and race to impact upon migrants' lived experiences in North America, the importance of geographic imaginaries as a form of representation in transnational communities, intimate impacts of North American bordering practices within transnational communities, and the use of discursive bordering practices to control and manage migrant flows in The Gambia. 


\section{Acknowledgements}

This thesis represents two years of active research and nearly five years of engagement with migration in The Gambia. As such, I am indebted to the many people and organizations who helped me to formulate thoughts and questions, and provided scholarly, emotional and material support over the years.

First, I am incredibly grateful for the financial support of the Explorers' Club Washington D.C. Group, whose Fieldwork and Exploration Grant funded my trip to The Gambia in 2019. My fieldwork in The Gambia would have been very different without the help and support of my research assistant, Ello Kandeh, who tirelessly juggled his job as a teacher with duties to his family to assist me in data collection. This project (and myself) benefitted greatly from conversations with Gibbeh Bah, Modou Ndure, Kebbah Touray, Momodou Alieu Bah (Bah2), Alhagi Jammeh, Fatou Sowe, Mariama Jammeh, Bassirou Manneh, Batouba Jarju, all of the wonderful people at Taal Kunda, Jarju Kunda, Kong Koto and my family at Kumoo Kunda. They provided a steadfast support network not only during my visit to The Gambia, but during my entire time as a Peace Corps Volunteer.

Thanks to James Courtright and Alyson Lush for many great conversations over the summer. And a special thanks to the members of Youth Against Irregular Migration for facilitating my participation in their public-engagement events.

I am also indebted to my fellow geography graduate students at WVU, particularly Jed DeBruin, Heidi Gum, Elizabeth Dever, Darren Gross, Meg Davenport and Shobha Yadov. I never would have finished this project or graduate school without their support. Thanks to my committee: Drs. Jamie Shinn, Tamba M'bayo and Cynthia Gorman, for their support, thoughts, feedback and mentorship throughout the project.

Finally, and most importantly, much love to my parents and sisters for their continued support over the years - even across the Atlantic Ocean - and to my wonderful partner Bella for never letting me forget why I started this project in the first place.

To all who shared their stories, provided insight, comments or support: 


\section{Table of Contents}

CHAPTER 1: INTRODUCTION, BACKGROUND, LITERATURE REVIEW AND RESEARCH QUESTIONS ......................... 1

1.1 A CASE StUdy OF THE GAMBIAN-NoRTH AMERICAN TRANSNATIONAL COMMUNITY ..................................................

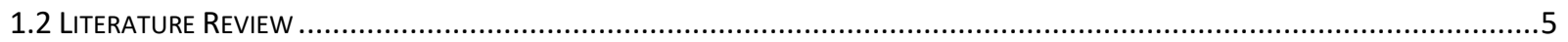

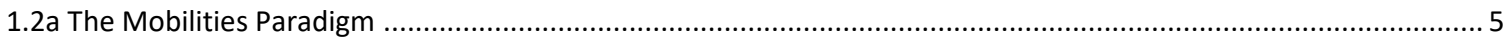

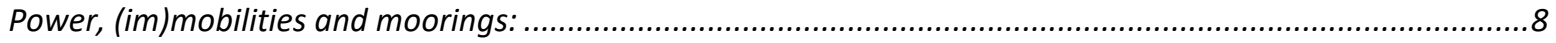

1.2b Feminist Geographies of Migration.............................................................................................................

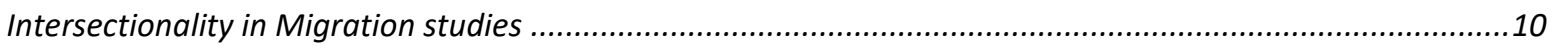

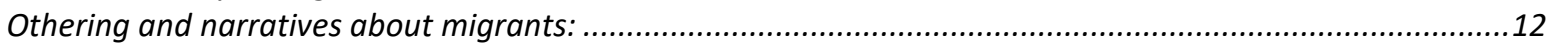

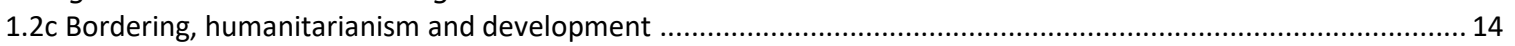

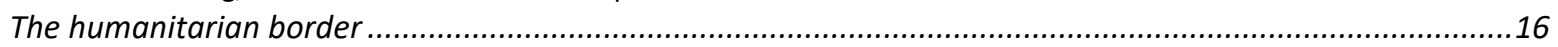

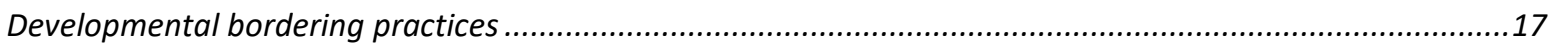

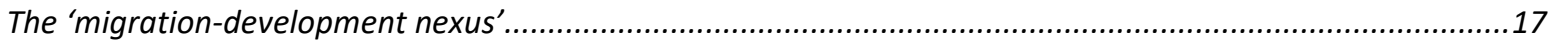

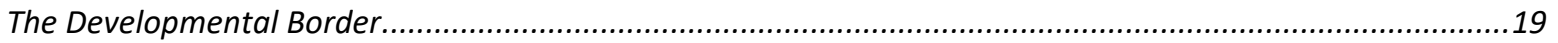

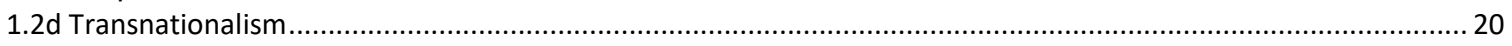

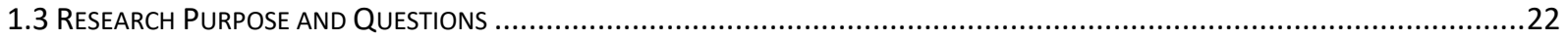

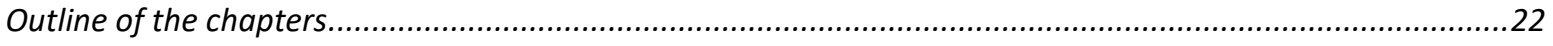

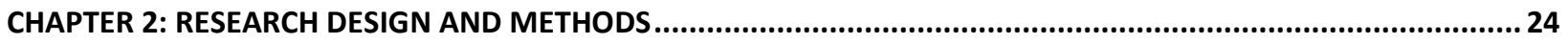

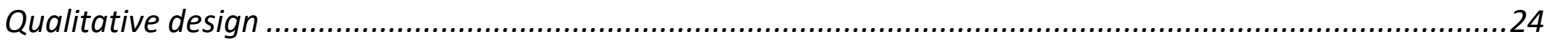

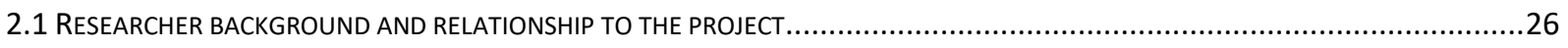

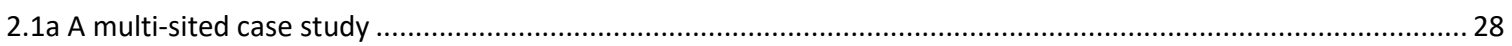

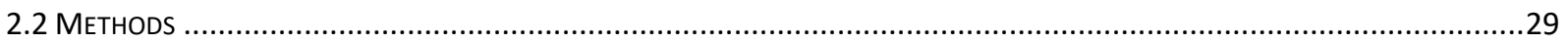

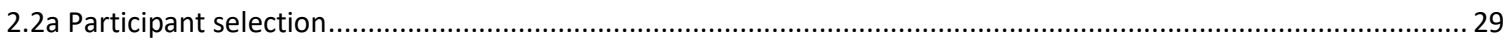

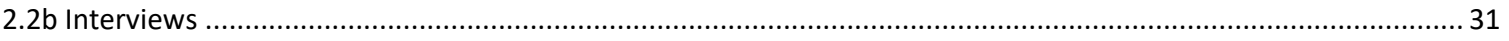

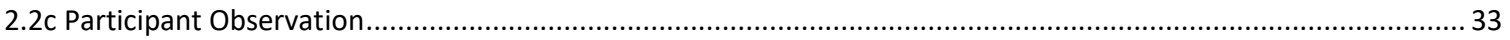

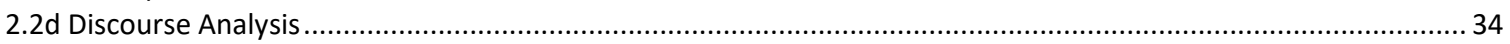

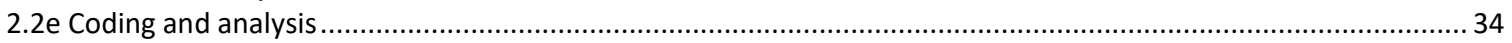

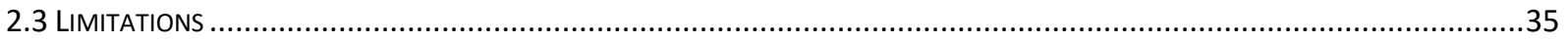

CHAPTER 3. SITUATING THE CASE STUDY: 'WAVES' OF MIGRATION .................................................................. 37

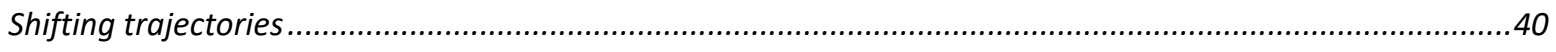

CHAPTER 4. 'MAKING IT': IMAGINED PLACES, EMBODIED EXPERIENCES..............................................................43

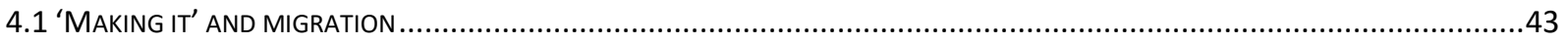

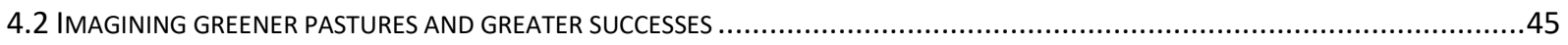

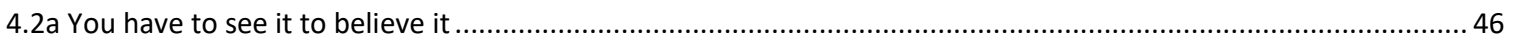

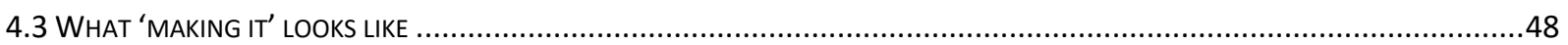

4.3a 'I didn't know what hard work was until I came here' ...................................................................................... 48

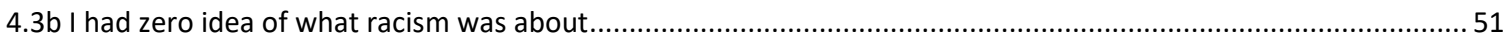

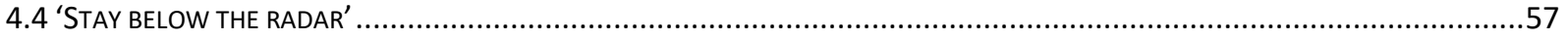

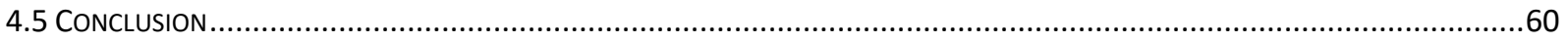

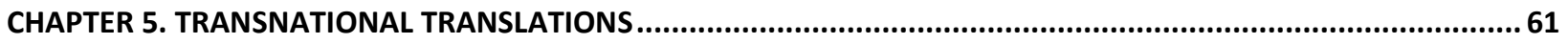

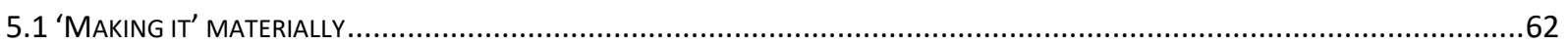

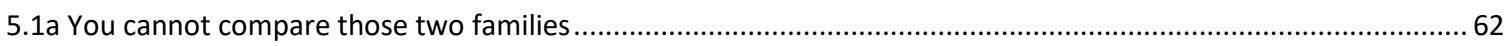

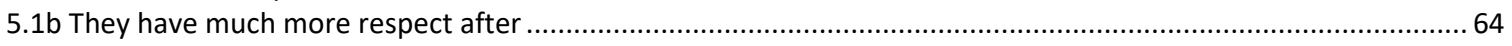

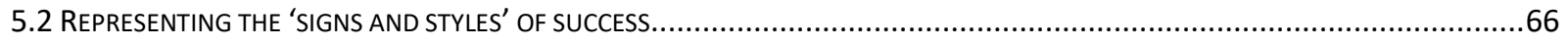

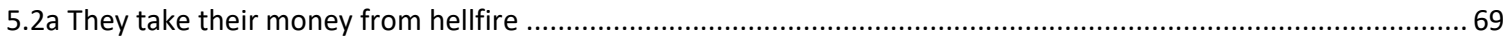

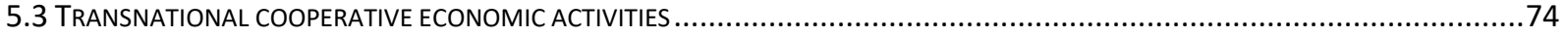

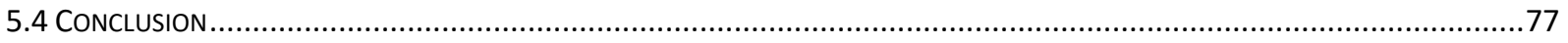

CHAPTER 6. TEKKI FII IN THE GAMBIA: DEVELOPMENTAL BORDERING AND IMMOBILIZING DISCOURSES........... 79 


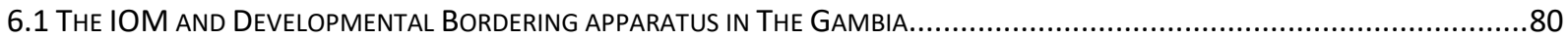

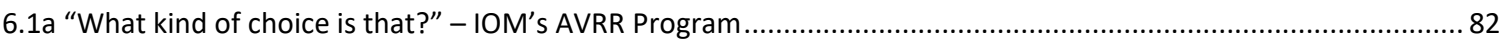

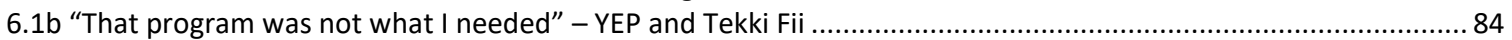

6.1c "Funding has really taken off for migration" - The IOM Development Fund .................................................... 88

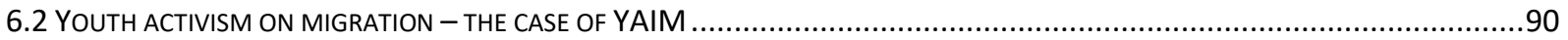

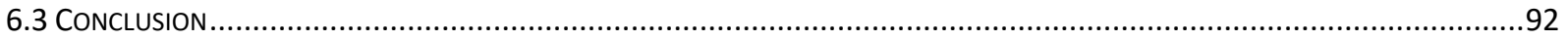

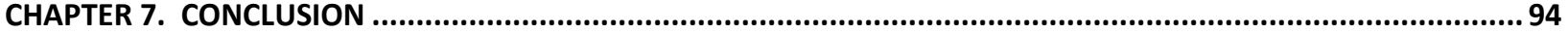

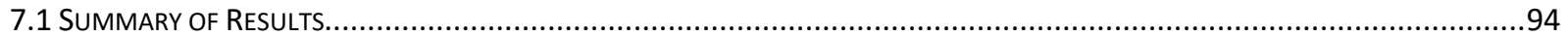

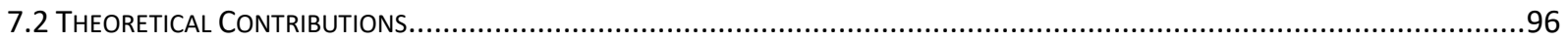

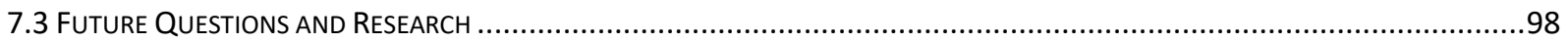

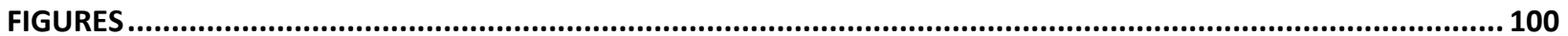

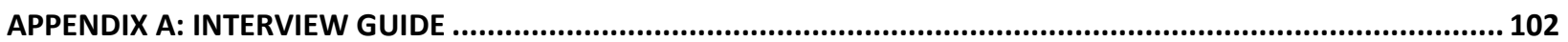

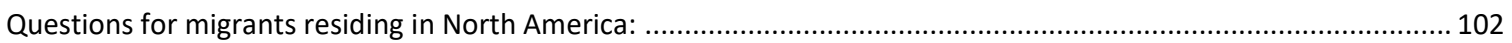

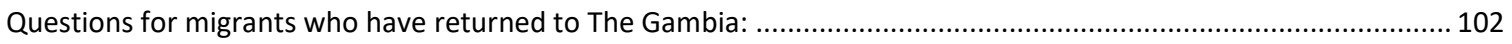

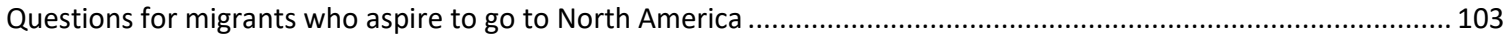

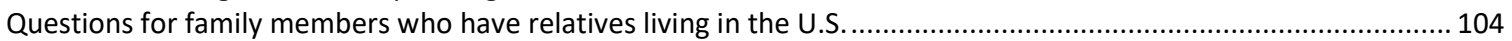

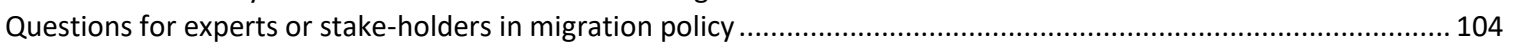

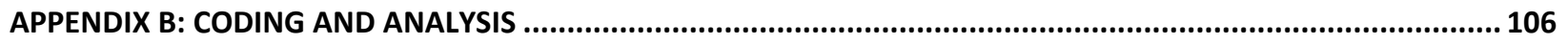

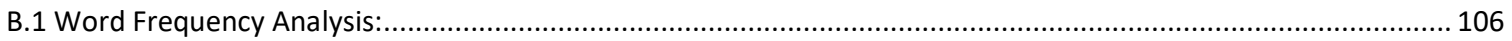

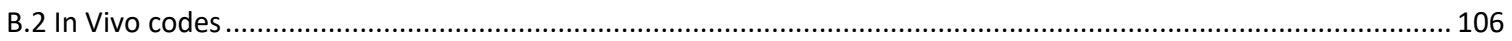

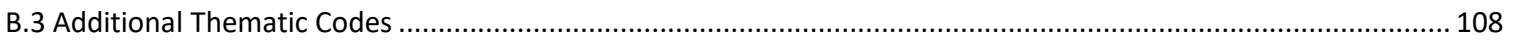

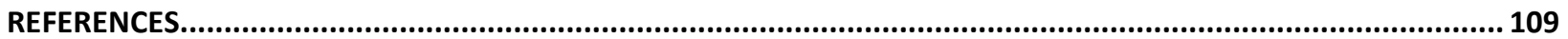




\section{Chapter 1: Introduction, Background, Literature Review and Research Questions}

At the end of January 2019, a plane landed at Banjul International Airport carrying twelve Gambian nationals who had just been deported from Germany (Altrogge and Zanker 2019b). As the plane touched down, their journey of many months, and in some cases, years, came to an end. All of these individuals had taken an 'irregular' route leading from Banjul, the capital of The Gambia, overland to Agadez in Niger and then across the Sahara Desert to arrive in Tripoli, Libya. From there, Libyan smugglers loaded them onto old fishing boats that they used to cross the Mediterranean Sea. They were likely intercepted by the Italian coastguard, or a search-andrescue operation run by a non-governmental organization (NGO) and booked at a processing facility where they would await their turn to claim asylum in the EU. Many, knowing full well that they would be treated as 'bogus refugees' (Neumayer 2005), did not wait around for their hearings and instead left the facility without documents to attempt to find work in Germany (Washington Post 2019), where they were subsequently detained.

Less than two weeks earlier, the Christmas holiday season came to an end in the greater Kombo area (the capital region in The Gambia). The same airport the deportees arrived to had been filled with Gambian families and individuals headed back to their homes in the United States (U.S.), Canada or Europe after a month-long visit to The Gambia. Many of these travelers sported the latest in both African and Western fashion trends, new smart phones and tablets, and often carried passports and visas granting them access to the places that their 'irregular' counterparts had so desperately been trying to reach. They waved at family members who had come to see them off - many of whom were now also sporting new clothing or phones received as gifts from the travelers. "See you next year!" they called, disappearing into the waiting area. They would be back in December to visit again. The twelve deportees who stepped off the German charter flight would probably still be in The Gambia by then, trying to eke out a living in the Kombo area. Perhaps they would be back in Tripoli, waiting for a boat to try their luck in Europe again. Perhaps their journey would have a different ending given the number of migrants' boats capsizing in the Mediterranean.

A quick Google search for the term "Gambian migrant" yields thousands of results. The terms "refugee", "illegal”, "deported", "irregular", "undocumented", "unskilled”, "risk”, "death" 
and "Europe" feature prominently on the first page of results. A deeper dive into the first few search results reveals the media attention to what has been called Europe's "migration crisis" (Park 2015), that "millions of Africans [are] flooding Europe" (Samuel and Squires 2017), and that "Tiny Gambia has a big export: migrants [who are] desperate to reach Europe" (Sieff 2015). It is clear where the deportees fit into these representations: they are the illegal ones, the refugees, the flood of unskilled labor. Unclear is where the travelers boarding the plane to return to states of the global North fit, and why their movement between The Gambia and the global North passes undocumented and un-politicized in news media while their counterparts' movements are the subject of intense interest, scrutiny, management and control.

Many scholars, journalists and policy-makers have taken an interest in Gambian migration in the past decade. They have examined the 'root causes' of Gambians' desires to migrate abroad (Bostrup and Frandsen 2017), documented migration flows and remittance economies (Kebbeh 2013), theorized development interventions that could solve the 'push factors' that lead Gambian migrants to take 'irregular' routes (Janko 2012), and analyzed why those interventions repeatedly fail (Gaibazzi 2011, 2015). Absent in this array of literature, however, is any discussion of the travelers seen boarding the plane at the end of the Christmas holidays. Indeed, scholarly literature on migration from West Africa at large consistently fails to examine migration outside of the narrative of 'crisis' and 'illegality' that pervade popular discussion as evidenced by the Google search. While important, these studies fail to examine migration within a broader context of social and power relationships, representations and lived experiences.

As the two vignettes of the Banjul airport make clear, movement from and through The Gambia is experienced and represented in highly variable, often contradictory ways. While much work has been done to situate the returnees within broader social relationships and power structures, few have engaged with the travelers: what their stories are, how their experiences are represented, and if those representations line up with their lived experiences of movement. It is to these un-politicized travelers that I turn first. By engaging with this group of mobile people, I hope to better reveal the sets of relationships and power structures that differentiate them from the returnees and govern the movement of peoples from The Gambia into other parts of the world. 


\subsection{A Case Study of the Gambian-North American Transnational Community}

Many of the travelers I introduced are a part of what I will term the "Gambian-North American (GNA) transnational community". This includes people of Gambian origin who, at some point in their lives, migrated to the U.S. or Canada. The GNA remains largely unexplored in scholarly and journalistic accounts of migration from the small nation. Despite North America's low visibility in the discourse surrounding Gambian migration, there are a substantial number of Gambians living there. The U.S. represents the second largest destination for Gambian migrants, after Spain, and the U.S. based diaspora is just behind the Spanish and German diasporas in the amount of remittances sent home (Kebbeh 2013). Gambians living in the U.S., in 2017 alone, sent home $\$ 34$ million (USD) in remittances, accounting for 2.2\% of the nation's GDP (World Bank 2018). Additionally, Gambians living in the U.S. invest considerable money in businesses in The Gambia, provide support for young Gambians who move to North America to earn bachelors' and masters' degrees, and wield considerable influence in Gambian politics (Courtright 2018). Their importance to The Gambia cannot be understated. A case study of Gambian migration to North America is necessary to fully understand the phenomenon of Gambian migration, and the social relationships that it creates.

But, perhaps just as importantly, examining Gambian migration to North America presents a crucial step towards destabilizing singular narratives about Gambian migrants that European governments and news media perpetuate. While other scholars have attempted to tease apart the complexity of discourses surrounding Gambians who migrate to Europe (Gaibazzi 2011; Prothmann 2018; Altrogge and Zanker 2019a), it remains challenging to do so amidst massive efforts on the part of European nations to control the way Gambian migrants are represented in media, literature and public discourse. Engaging with the linkages between lived experience and representation in the GNA migrant community affords the opportunity to examine these nuances in a less politicized setting. By this, I mean that neither The Gambian Government, North American governments, nor other stakeholders such as NGOs have made significant investments to shift and frame representations of Gambian migrants in North America as they have in the case of Gambian migration to Europe. Absent the intervention of the state or its agents, representations of migration between The Gambia and North America remain largely produced by migrants themselves, or their family members. It is within this relatively depoliticized environment that the mobilities framework can be applied to explore how migrants 
experience migration, how representations of their experiences are formed, and then how migrants may change those representations. The findings of this case study may then further inform and tease out how those engaged in migration experience the process and produce meaning, and the ways this comes into conflict with state and NGOs' attempts to control narratives about migration - how movement is given meaning.

\subsection{Literature Review}

To attend to these issues, a robust theoretical framework is needed that holds at its foundation the way mobile people experience movement, the way their movement is represented, and the structures of power that shape these representations. I take, as a starting point, the mobilities paradigm, which above all seeks to understand the relationship between movement and meaning: how they are practiced, experienced and embodied. From there, I build outward to attenuate the mobilities paradigm to the specific needs of the case study. Feminist geographies of migration will provide the epistemological tools necessary to explore the relationships between lived experience, representation and power. Geopolitical studies of bordering, humanitarianism and development provide further perspective to situate European actors' attempts to manage and control migrants while shifting and framing the discourse about migration. Finally, transnationalism destabilizes the assumed primacy of the state in the social relationships governing migration and situates migrants as agents in the process of creating representations, not simply passive actors.

\section{2a The Mobilities Paradigm}

The mobilities paradigm emerged out of the broader 'cultural turn' in geography and the social sciences in the mid 1980s. While scholars of the previous era of migration studies sought to quantify migrant flows, understand causes and create models to predict future migration events, mobilities scholars instead work to understand the stories of mobile people, the relationship between movement and identity, and movement's embeddedness in politics and power. They examine not only forms of movement excluded from traditional migration studies, such as commuting (Jensen 2009), but explore the essence of movement itself. While early migration studies portray mobility as a single event, a displacement from point A to B that can be explained through "push and pull" factors (Heberle 1938) and quantified through models (Zelinsky 1971; 
Grigg 1977), the mobilities paradigm instead engages with the context of the line between points A and B to show how "despite its apparent immateriality, [it] is both meaningful and laden with power (Cresswell 2006, p. 9). Tim Cresswell's (2006) On the Move, represents one of the foremost texts on the mobilities paradigm within which he develops the "logic of mobilities".

Cresswell takes as a starting point the statement that the "movements of people (and things) all over the world and at all scales are, after all, full of meaning. They are also products and producers of power" (2006, p. 2). Cresswell indicates that mobility must first be understood as "socially produced motion" (p. 3), and offers three ways through which mobility may be understood: mobility as observable phenomenon through space and time; ideas about mobility that are conveyed through representational strategies; and mobility as embodied, practiced and experienced: a "way of being in the world" (p. 3).

Furthermore, the two latter ways of understanding mobility are intimately linked: ways in which people experience mobility are influenced by the ways mobility is represented, just as the ways mobility is represented may change based upon peoples' embodied experiences. Take for example the experiences of two different people walking through a forest: one is an American citizen on a dirt pathway somewhere in the U.S., and the other is a Gambian walking through a forest in Morocco near the Spanish enclave of Ceuta with the hopes of crossing into Ceuta and onto Spain and the EU. The American hiker might experience their walk as refreshing and rejuvenating based off of the ways hiking is represented in films and advertisements for outdoor clothing companies. They might then reinforce these representations of hiking when talking to their friends. The Gambian might experience their walk as exhilerating, based off of stories of adventure from friends, or may experience it as terrifying, based on their proximity to the militarized Spanish border, or stories of brutality at the hands of police. Experiences of mobility are influenced by the ways it is represented, and those experiences can then in turn become representations when shared. This is especially true for migrants, whose experience of travel might be influenced by what other migrants have told them about the journey. They may in turn influence future migrants through their own depictions of traveling.

However, as Cresswell notes, these are not just "physical bodies moving through material landscapes", they are also "categorical figures moving through representational spaces. Mobile people are never simply people - they are dancers and pedestrians, drivers and athletes, refugees and citizens, tourists and businesspeople, men and women" $(2006,4)$. These two different, yet 
very similar people walking through a forest are situated within broader ideologies of movement, or systems of meaning that link lived experiences to representations of mobility - their movements are impregnated with meaning. Those meanings, in turn, are intimately linked to dominant power structures that tell stories about why people move. The American may express a need to "get out of the city", or to "get back to nature" as the reason for their walk in the woods that they expect to be refreshing and rejuvenating. The ideology of escaping the city and getting closer to nature may be in turn linked to historical justifications behind the expansion of settlercolonial states, like the U.S. and Canada. The notion of the city as unhealthy, unnatural, or unmanly was pointed to as a reason why people needed to move to the frontier and expand outward. The meaning behind a notion of masucline expansion can jump scales and times, informing movements like walking in ways that are barely perceptible. In the case of the Gambian, their excitement or fear may be linked to broader representations of migration between sub-Saharan Africa and Europe. They may be excited by images circulating on social media of 'living the good life' in Spain or Italy, or at the thought of being able to send Euros home to family. If they are apprehended, their interaction with border guards and police may be informed by the rhetoric of 'crisis' or 'invasion', where images of criminalized brown and black people flowing into Europe set the stage for a confrontation between cultures, races, religions and territories, rather than a simple encounter between two human beings in the forest. Such ideologies of movement shape how mobility is represented to the lived experiences of mobile people. These are no longer just people walking in the woods. The American thus becomes a hiker, the Gambian a migrant. Their situation within representational spaces changes everything about how they experience this walk in the woods.

Furthermore, the relationships between meaning, movement and the practice of movement are not static, they change over time and space, and depending on who is moving. Depending on their appearance and class status, the American walking in the woods may not be a hiker, but a vagrant. The Gambian, crossing the border into Ceuta in 2020 may be labeled an illegal migrant or undocumented person, whereas if they were crossing in 1995, they may have been a labor migrant or seasonal worker. The different meanings given to movements shape the ways that people move, and often, result in differentiated abilities to move depending on how someone's mobility is represented. 


\section{Power, (im)mobilities and moorings:}

While modernity is often equated with increased mobility for all, scholars have used the mobilities framework to illustrate hierarchies of movement; that some are more able to move than others. Hannam, Sheller, and Urry (2006) situate the mobilities paradigm as fundamentally opposed to the notion of "nomadic theory", or the idea that modernity has resulted in democratization of movement around world, eroding the nation-state and allowing equal movement for all. They introduce the terms "immobilities" and "moorings", however, as vocabulary to describe how the project of modernity has not benefitted all equally - many are immobilized or moored in place despite the increased mobility of others. Cresswell, however, problematizes the mobile/immobile bifurcation, arguing instead that "kinetic hierarchies" (Cresswell 2012) better represent the notion that even those who are "immobile" may still move, but this movement may look very different from that of kinetic 'elites'. Whether using the language of mobile/immobile or kinetic hierarchies, exploring these power dynamics can begin to elucidate the meanings that underlie mobility.

Many scholars have begun to study these power relationships through the lens of the tourism industry. The international mobility of highly privileged, often white, 'nomadic' tourists comes with the immobilization of enormous workforces, often women of color, to provide services as they travel (Hannam, Butler, and Paris 2014; Heller, Jaworski, and Thurlow 2014; Schurr 2019). Many Gambians have their first interaction with white people of the global North while working in the tourist industry in the tourist resort area just outside of the capital. Wealthy British, Dutch, German and Spanish tourists often come to spend time on the beach, go on 'safaris' and spot 'exotic' birds during the winter months in The Gambia. While tourists spend exorbitant sums of money on tours, hotels, dining and souvenirs during their stay, many Gambians work to clean their hotel rooms, shuttle tourists around the country, prepare their food, provide security and in many cases, provide sexual services. The Gambia is notable as an international destination for sex tourism and specifically caters to older European women seeking a romantic encounter with young African men, locally called 'bumsters' (Chant and Evans 2010). These tourist trips and sexual encounters often end after 10 days and the white tourist is free to travel in comfort and security back to their home. The Gambian serviceproviders, however, often do not have access to visas to visit Europe or North American destinations for similar types of pleasure and leisure. They remain immobilized in The Gambia. 
Such encounters produce and reinforce images of whites as mobile and wealthy, and Gambians by comparison, as immobile and poor. These encounters form the basis for many imaginings of what life in 'western' nations might be like, and the kinds of experiences one can have if they are mobile.

While power structures are indeed made visible by the literal immobility of those who provide services to mobile people (Adey 2006; Borovnik 2012; Pratt 2012), they may also be seen in people's differentiated abilities to move or the conditions within which they move. While European tourists, business travelers or international students may experience relative ease, comfort and security of movement, Gambian migrants hoping for access to the same lifestyle may find themselves "adrift in geopoliticised fields of power" even as they move (Ashutosh and Mountz 2012, p. 336). Unequal geographies of power imprint themselves upon migrants in ways that make their mobility less fluid and more precarious than mobile elites. Doreen Massey (1993) explains this relationship as the 'politics of mobility and access', arguing that different groups of people have different relationships with and different access to the ability to move. Massey's framework begs the questions of 'who has access to mobility, and the ability to represent it? And 'what does access look like?' While Domosh and Seager (2001) note that this difference is often construed on the basis of socio-economic class, Cresswell (2006) indicates that the way certain people are represented as "criminal" or "security-threat" play a large role in this differentiation. How then are these representations produced, and what role do powerful actors have in enforcing them? To further engage with the politics of mobility and access, I turn to the contributions of feminist geographers have made to migration studies.

\section{2b Feminist Geographies of Migration}

While the mobilities paradigm lays the foundation of my theoretical framework, the work of feminist geographers is crucial to examine how different people experience movement, are represented as they move, and what meanings are given to their mobility as they traverse international borders and geopolitiscised fields of power. Their approaches stem from the notion that all experiences and knowledge are situated at the scale of the body (Haraway 1988). Rachel Silvey (2007) argues that "the body is a theoretically powerful starting point from which to study migration" (152). For much of the history of migration studies, representations of migrants were produced without the situated knowledges of migrants themselves. Much of feminist 
geography's contribution to migration studies has been in the process of incorporating migrants' lived experiences into the ways migration is represented, often using intersectional analyses (Crenshaw 1991) to explore the ways that migrants' identities intersect to shape their experiences, and in turn influence how they are represented. Here I develop an intersectional framework to begin unraveling how identity is related a person's lived experiences of movement, and how they have access to representing their movement. I then examine geopolitical narratives about mobile people to begin explaining the role that powerful actors have in ascribing meaning to movement.

\section{Intersectionality in Migration studies}

Early on, the process of gendering migration was a key task in examining migrants' lived experiences. Feminist thinkers demanded recognition of large female migrant labor forces that had been overlooked by demographic migration studies of the $20^{\text {th }}$ century, and specifically, to shift women from subjects to social actors (Campani 1995). A slew of studies emerged from multiple disciplines documenting and gendering migration and mobility during this period, paralleling the 'cultural turn' (Phizacklea 1983; Morokvasic 1984; Chant 1992; Halfacree and Boyle 1993). Geraldine Pratt's work with Filipina migrants has brought to attention the dominance of women as migrants and providers in the Philippines, and the particular ways in which their role as women and mothers complicates their separation from their families in ways that male migrants may not experience (Pratt 1999, 2012). So too, George (2005) reveals how women often migrate before any other family members due to their ability to work in 'care' jobs, and act as "stakes" for the rest of their families to immigrate and be reunited.

While these attempts to make women's movements and labor more visible completed important work to deconstruct the supposedly ungendered migrant, it did lead to new assumptions that to "gender" migration explicitly meant to centralize women and women's experiences. The process of redressing historical gaps in research often made gender synonymous with women. Rather than simply marking certain movements as 'feminine' and others as 'masculine', feminist geographers began to critically engage with the terms 'man' and 'woman', examining the meanings that emerge from these categories and "the concept of gender, in the context of social identities and social relations more broadly" (Bondi and Davidson 2005, p. 15). It became important not only to attend to the forms of movement considered 'masculine', 
but to examine the meanings that connect lived experiences of men's movement to representations of masculinity. Some geographers have attempted to link contemporary migrations to historical notions of "men's work". Much work has been done in West Africa to link men's migration to historical notions of travel and masculinity. Prothmann (2018) shows how contemporary migration in Senegal is embedded in historical practices of men migrating not just to find work, but to become an adult - it is a rite of passage through which boys must go to become established adult men. Sinatti (2014) concurs, showing how migration in Senegal is often used as a pathway towards assuming the role of provider for a family. However, as Cheikh Anta Babou (2008) notes, migration often shifts and morphs gender roles. His case study of female Senegalese hair-braiders in Philadelphia illustrates that women, through the process of migration, often assumed masculine provider roles for their families. Prothmann finds, as well, that in the process of working abroad to assume the role of an adult male provider, young Senegalese men must often take jobs in Europe that they deem to be 'feminine', such as cooking and cleaning.

Migrants are not only gendered but comprise a multiplicity of identities that intersect and affect how they experience movement. These identities, too, become shaped and constituted by the process of migration. Melissa Wright's (2013) book on female laborers in the international export zones of China and the maquiladoras in Mexico show how their bodies are raced, classed and gendered to produce them not simply as 'un-skilled' labor, but as replaceable body parts: hands, and eyes, which require strict regulation, oversight and demands of productivity which result in high-turnover. Additionally, Flippen's (2014) analysis of the various identity categories that impact Central American migrants upon their arrival in the U.S. reveals a host of categories beyond race, class, gender and sexuality. The intersection of legal status, labor market position and family characteristics represent equally important categories in migrant communities and affect their ability to secure work. Clearly then, in the case of migrants, a multiplicity of factors emerge which create an intersectional embodied experience of movement. These factors add to the categories of race, class, gender and sexuality which Crenshaw (1989) theorized in her original paper on intersectionality.

Intersectional analyses of migration can be further contextualized within the broader geographies of difference that characterize how intersecting identities produce corporeal realities for migrants when moving into 'western' spaces. McKittrick's (2006) Demonic Grounds 
explores the spatiality of blackness in the African diaspora, specifically that created by slavery. Her analysis reveals that the carceral geographies associated with American slavery have continued to inform contemporary black geographies. She shows how the racialization of black bodies translates into a spatial consciousness; that race and space are intertwined. Certain timespaces racialize the bodies that are present there, just as certain bodies racialize the time-spaces they are present in. Rashad Shabazz's (2015) Spatializing Blackness expands on McKittrick's analysis, showing how black (im)mobilities are produced by carceral geographies that race, class, gender and sexualize black peoples' bodies, coding them for particular times and places. These carceral geographies are further informed by class and gender divisions within black communities. They are imprinted onto peoples' bodies so that a particular combination of identities is coded as welcome, unwelcome, criminal or dangerous in particular time-spaces (Silvey 2006).

Such codings of the body are crucial examining the movement of migrants into spaces fraught with racialized histories of oppression. While a recent migrant from Africa may not consider themselves "black" per racial formations present in the U.S., through the process of migration, their bodies become coded according to existing categories, and they may find themselves pulled into particular geographies of difference. Paul Gilroy (2016) notes that recent migrants may experience this as a tension of identities - where their inherited/ascribed identity conflicts with that of their 'homeland', forming what he terms a 'double consciousness' (ibid. 1993). Clearly, an intersectional framework is of use in understanding the lived experiences of migrants who come into spaces with unfamiliar categories of identity and racial formation. However, geographies of difference have effects that reach far beyond the scale of the body, expanding into national discourses and debates that generate representations of who migrants are and why they move. These can form powerful geopolitical narratives that assign meaning to migrant mobility.

\section{Othering and narratives about migrants:}

Othering has been explored by many geographers, but Houtum and Naerssen (2002) provide an overview of its effects, both on migrants who are settling in a nation and on the particular patterns of migrant settlement produced by othering. New migrants may select areas densely populated by immigrants also perceived as "others" in order to reduce their feeling as an outsider 
or a stranger in areas where they are othered. The image, or representation of migrants as others can provide political fodder for ongoing debates about which kinds of bodies are welcome and which should be excluded (Mountz 2009). Hyndman (2005) terms these debates the "migration wars", noting that this discourse "continue[s] to produce images of the menacing other and the migrant-as-security-breach, and embolden efforts to wall off wealthy countries from poorer ones" (6). Hein de Haas (2008) argues that these images form 'myths of invasion' which shape political opinions and responses to migration on a national or international level. Such myths can form the basis for 'floodgate arguments', or visions of a descent down a slippery slope of national policy-making (Gorman 2019). While some have focused on national-scale narratives, Virginie Mamadouh (2012) indicates that migration narratives are not uniform across scales, and that people develop myths about migrants at the neighborhood scale, the city level, and the national or regional (in the case of Europe) scale. Narratives serve multiple purposes and are used in different political circumstances as necessary to achieve particular goals.

Nationalist narratives play an important role in shaping representations of migrants in certain situations: African migrants in the EU and Central Americans in the U.S. are two group who have been the subject of an 'invasion' discourse perpetuated by politicians and mainstream media, However, narratives constructed at the 'national' scale, in the case of the U.S., or the regional scale in the case of the EU, may embolden individuals to take action themselves against migrants. As Jones (2016)_illustrates in the case of India, the presence of border fences and militarized bordering practices may embolden individuals to take action against migrants at the community level. But overt violence is often not the primary way that migrants are othered. Cresswell (1997) indicates that metaphors are often employed in the process of representing others. Metaphors relating to "weeds", "illnesses", or "bodily secretions" situates people as undesirable, or 'out of place'. Ellis and Wright (1998) expand on the use of metaphors, noting instances where migrants are not necessarily viewed as out of place, but as bringing unwanted diversity to the U.S., resulting in "balkanization". In this instance, the metaphor not only situates migration as unwanted, but portrays the U.S. as a culturally homogenous population under threat from 'others'. however, Not all othering processes portray migrants as negative. Ahmed (2013) shows that while often, the view of a migrant as "other" portrays them as dangerous, an instigator of unwanted changes, an impurity in a community, "others" have also been portrayed in a positive light in line with liberal multicultural projects to increase "diversity" in 
communities. In this sense, the migrant body is perceived as bringing 'culture', 'color', or 'vibrancy' to spaces which would otherwise be homogenous or 'white'. Ahmed argues that this view can be problematic as well, as it produces 'stranger fetishism' - a modern form of oriental obsession with difference. Narratives of Gambians who enter the EU are much more likely to be framed along the lines of what Haas describes as the "invasion" discourse, as they are a part of the larger scale African immigration portrayed by many as a crisis. In the U.S., however, while certain African migrant and refugee communities, particularly Somalis, have been the subject of public discourse, Gambian migrants, due to its small size and lack of public and discursive visibility, has allowed Gambians to remain relatively depoliticized as Gambians in the U.S., although I will argue that they may be drawn into other narratives about mobile people that are not based on a national identity. This has not been the case for Gambians who travel to Europe, who find their movement frequently framed using the language of 'crisis' and 'invasion'.

\section{2c Bordering, humanitarianism and development}

Perhaps few contemporary practices affect how human mobility is experienced and represented more than state bordering. As Castles, Haas, and Miller (2013) indicate, global migration rates have remained similar since the 1940s, but the "political salience of migration has increased" (p. 1) as governments and policy-makers put increased effort towards creating borders and regulating movement. By extension, these practices situate the unregulated movement of people across borders as a challenge to state sovereignty. Jones (2016) further argues that territorial bordering practices in the nearly four centuries since the Treaty of Westphalia have produced and reinforced a "system that seeks to preserve privilege and opportunity for some by restricting access to resources and movement for others" (p. 16). Here, I briefly outline a few key shifts in state bordering practices in the last three decades, and how they both materially and discursively shape human mobility.

While the 1990s saw a surge of interest in an increasingly borderless world, in the post9/11 era, many nation-states have sought to reassert control over their sovereign territory. The control and maintenance of territorial borders takes on many forms but for the past three decades, many states of the global North have hardened and militarized their borders. Indeed, as Jose Palafox (2000) indicates, in the context of the U.S. border with Mexico, the “opening' of the border for a global marketplace has coincided with the "closing' of it to the movement of people" (2000, p. 58). increased border militarization has a symbiotic relationship between state 
enforcement and smuggling networks. As Peter Andreas (2001) argues, U.S. border enforcement and smugglers from Mexico, Central and South America have engaged in a long process of increasing militarization in response to each other's changing tactics, routes, use of weaponry and visibility. Uli Linke (2018) indicates that similar processes occurred in Europe in the early 2000s.

Governments, militaries and police of the global North have deployed many different bordering mechanisms and practices in response to the perceived threat of both migrants and smuggling operations. This includes border walls, fences and militarized border patrols (Jones 2016), and the alteration of state geographies to prevent migrants from accessing a state's territory to claim asylum (Hyndman and Mountz 2008). As states continuously harden and militarize their borders, safe and legal channels for people escaping violence and persecution or seeking economic opportunity are closed and eroded away (Pallister-Wilkins 2015). Now, more than ever, mobile people come into contact with militarized borders. This has resulted in increased amounts of death and suffering at the border over the past several decades.

Just as states across the globe invest significant resources in the material production of borders and walls, police forces and policies, they also attempt to shape the discourses about who mobile people are, and why they move to justify these bordering tactics. As Gorman (2017) shows in the case of asylum law, material and discursive bordering practices work together to exclude people from certain spaces. The shifting language people use to talk about movement helps to explain this relationship. Use of the term "terrorist", rather than "migrant" or "refugee" by President Trump and the press to describe the caravan of Central American who traveled together to seek asylum in the U.S. justified deploying U.S. military troops to the border, rather than mobilizing humanitarian operations (Gibbons-Neff, Cooper, and Kalifa 2018).

More subtle attempts to shape the discourse about mobile people also takes place in West Africa. In Wolof, a regional language prevalent in Senegambia, the term tukki (to travel) has historically been used to describe many kinds of human mobility - from visiting a neighboring village, to traveling abroad to seek work, to engaging in trans-Sahara trade networks. But as European state and non-state actors increasingly attempt to regulate international mobility in West Africa, English borrow-words have entered the Gambian lexicon. Words like 'migrant', 'refugee', 'illegal', 'irregular' and 'undocumented' are now commonly heard in conversations taking place in Pulaar, Wolof and Mandinka. As recently as 2017, road-side billboards funded by 
European NGOs could be seen across The Gambia proclaiming that "Irregular Migration is ILLEGAL", or "The Back Way is Illegal" (the 'Back Way' is the colloquial term for trans-Sahara migration routes that go through Libya). Where material border walls, fences and police protect Europe's borders around the Mediterranean Sea, discursive bordering practices that situate migrants as 'illegal' and 'criminal' extend far into the Sahel, attempting to define and classify migrants and immobilize some through language before they ever leave home.

\section{The humanitarian border}

The increase in physical, legal and discursive violence that accompanies the militarization of borders has come under scrutiny in the past decade. State and non-state actors have shifted tact and now increasingly situate migrants as people in need of care, or as victims. Migrants' stories, images of their suffering and death, often at the hands of smugglers, and appeals to universal humanity are now commonplace in news media. In what Kühnemund (2018) refers to as the "visual-political process", such spectacles of suffering at the border are mobilized by governments, humanitarian groups and NGOs to prevent death and provide care to migrants. The increased provision of aid at the border has led to what Pallister-Wilkins (2016) refers to as 'humanitarian borderwork'. Here the logic by which migrants are viewed shifts from criminality to that of grieveability. Importantly, this discursive move from law-breakers to suffering peoples in need of care is contingent on situating migrants as victims not of violent bordering practices, but smugglers, war, and poverty. This thesis engages with how these shifts in logic have not ended the military border or the criminalization of migrants but has created space for different regimes of territorial border enforcement that shape discourses about who migrants are and why they move.

The humanitarian border emerged amongst efforts, William Walters argues, to attend to suffering at various zones of humanitarian governance along nation-state borders (2010). These zones are now sites where the violence of nation-state territorialization is negotiated. In this context, borderwork draws logically from the humanitarian principles of saving lives and relieving suffering rather than those of stopping migrants and securing territory. This is not to say that the outcomes of humanitarian borderwork are substantially different from a regime of militarization, but that the defining logic has shifted. Migrants are still immobilized, but are represented as victims, or people without agency, rather than criminals or terrorists. 
Humanitarianism at the border, and the resulting discursive shifts have formed the basis for novel bordering practices that operate not in the borderlands of the global-North, but in what policy documents refer to as the "sending states" of the global-South. These new practices utilize the existing organizational structures of the development industry to both materially and discursively shape how people experience movement and how their movement is then represented.

\section{Developmental bordering practices}

As migration from West Africa increasingly becomes represented as a 'humanitarian crisis' to which western nations must respond, academics and policy makers have turned to development interventions in an attempt to 'stem the flow' of migrants into western spaces - to resolve the 'push factors' that cause migrants to leave. Many of these projects assume that migrants are primarily motivated by economic reasons and that if issues can be addressed in the 'sending states', migrants will stay at home (Haas 2007). While developmental bordering practices operate under the assumption that material changes in 'sending states', such as micro-loans and jobtraining programs, will reduce migration, they also invest significant resources in publicrelations campaigns, radio shows and other forms of media that attempt to shape the discourse surrounding migration. Here I will briefly trace developments in the body of literature, referred to as the 'migration-development nexus', that draw links between economic development interventions and reductions in migration flows. I then illustrate how developmental bordering practices grew out of both humanitarian interventionism and the ideas of the 'migrationdevelopment nexus'.

\section{The 'migration-development nexus'}

Early scholars on this subject, such as Böhning (1994), indicated that undocumented migration was primarily caused by a widening income and trade gap between countries of destination and countries of origin. Böhning proposed a number of economic fixes to curtail undocumented migration, including the expansion of trade agreements, increased foreign direct investment in states of migrant origin, and development assistance to the communities that produce migrants. Lavenex and Kunz (2008) show that this view has gained acceptance over time: European Union policies have shifted from simple attempts to repress migration at the border to proactive 
approaches seeking to stem migration at the source through economic development packages. However, there is disagreement as to what form of development will best achieve these ends. Nyberg-Sørensen, Hear, and Engberg-Pedersen (2002) note no link between economic development projects and a reduction in migration, but that foreign aid in times of humanitarian disasters or conflicts can be linked to a reduction in the number of refugees and subsequent asylum claims.

Other scholars, however, have taken issue with the notion that developmental interventions can halt migration and argue that migration can, in fact, be the best pathway to 'development' for a particular state. Proponents of the New Economics of Labor Migration (NELM) have found that migration, and the remittance economies that result, provide more in the way of tangible improvements to the 'sending state' and poverty alleviation than development projects and foreign aid have. One of the earlier writers on the subject, Taylor (1999) indicates that remittances can play a powerful role in transforming developing states and providing a form of direct investment that does not otherwise exist. These debates over the relationship between migration and development have, over the past two decades, begun to play out within the context of West Africa, where governments, charities and NGOS have rushed to implement 'stay-at-home' projects to immobilize young migrants before they leave home. In 2012, the Government of The Gambia implemented "Project No Back Way to Europe”, an EU funded government initiative to pay young Gambian men to stay at home and grow food, rather than take the so called 'Back Way' (Janko 2012). Gaibazzi (2011) explored in detail a similar program that paid young men a salary not to migrate. In many cases, however, this salary was used to maintain the family home and fund siblings or relatives to migrate instead.

Lama Kabbanji (2013), however, in a discourse analysis of official language pertaining to migration and development in Senegal, reveals the top-down pressure European governments place on West African states to shape the discourses about migration. Kabbanji shows that the official stances and policies of the Senegalese government are shaped by the discourse the migration-development nexus perpetuates:

The migration-development nexus has thus only very recently been incorporated into the Euro-African regional policy agenda, concomitant with the emergence of a discourse conveying images of Europe 'invaded by illegal migrants from sub-Saharan Africa', and 
'Africa deserted by its unemployed young people'. This discourse is mobilised by

European and African institutions and through multi-lateral initiatives between the two regions to justify increasing interventions in the field (p. 418)

Kabbanji reveals that EU funding for development projects in Senegal is contingent upon the Senegalese government not only implementing policies to stop migration and to repatriate migrants, but also upholding the discourse perpetuated about migrants by the migrationdevelopment nexus, despite a growing realization among Senegalese officials that the remittance economy has provided much more in the way of aid than official European development projects. The increased marriage of the ideologies of the 'migration-development nexus' with policy has resulted, some scholars argue, in new kinds of bordering practices.

\section{The Developmental Border}

As Kabbanji indicated, by 2009, the ideas of the 'migration-development nexus' had only just begun to hold sway with governments and policy-makers in West Africa, and that discussions about migration governance largely played out in unilateral or bilateral negotiations between different state actors. Since then more powerful, non-state actors and NGOs have begun to dominate the kinds of material and discursive negotiations that take place between West African governments and the EU. Frowd (2018) and Pécoud (2018) argue that in the Sahel region, the International Organization for Migration, or the IOM has become a powerful actor that has significant influence over migration governance.

Frowd's case study of the IOM in Mauritania reveals a new set of relationships between bordering practices and the development industry: relationships he terms the "developmental border". He argues that these "efforts to 'manage' migration, partly through border controls, but also through other policy tools, increasingly draw on the discourse of development but also its financial resources, forms of organization, and implicit understandings about the world" (2018, p. 2). The development industry, constantly responding to shifts in funding and policy, has become a useful ally through which to extend the borders of the global North to 'sending states'. The IOM has been a chief facilitator between the territorial bordering practices of the EU and the governments and development practitioners of West Africa. 
While powerful entities such as the IOM exercise power over both material and discursive aspects of migration, they are not the only entities that do so. Migrants themselves exercise considerable agency in both the ways that they navigate the constantly shifting landscape of physical, legal and social borders, and in the ways they represent their own mobility. Indeed, in a world where the state attempts to exercise increasing control over human movement, migrant mobility and the new kinds of social relations it creates and sustains may represent challenges to the authority of states and their agents.

\section{2d Transnationalism}

Increasingly, migrants engage in activities that do not fit neatly into the theories utilized in classical migration studies: words like 'sending' and 'receiving' states are problematized as migrants seasonally move between different states for work, remit money, goods and ideas to their 'home', and remain politically and socially engaged via social media in their state of origin. As Castles, Haas, and Miller (2013) indicate, "the old dichotomy between migrant-sending and migrant-receiving countries is being eroded - if this dichotomy was ever valid at all'(p. 13). But it is not just migrants who are on the move in a transnational world - so are finances, goods, ideas, technologies, discourses and representations. Transnational relationships, now more than ever, play an important role in shaping how international mobility is represented.

Transnational thought represents a break with "grand theories" of migration that portray international mobility as a single event: either a permanent separation from the place of origin, followed by assimilation, or as a temporary event followed by a return home (Gregory et al. 2009). As migration scholars increasingly employed anthropological methods to study migration (Champion and Fielding 1992), a focus emerged recognizing that migrants maintain complex relationships between the place of residence and their place of origin (Blunt 2007). This relationship became known as transnationalism, and it encompasses many aspects of migrant life. Basch, Glick Schiller, and Blanc (1993) describe transnationalism as a multiplicity of relationships - economic, social, familial and political - linking migrants between states and across borders. They regard migrants' experiences as transcending state boundaries, either through continued circular migration, or through a network of connections (ibid. 1995). Migrants' existence in multiple states has important implications for citizenship and identity, with migrants now recognized as maintaining political and social links across borders. Smith and 
Guarnizo (1998) indicate that modern patterns of transnationalism have only recently become possible through the development of transportation and communications technology capable of maintaining these relationships across great distance.

Transnational thought has emerged across the social sciences as a means to address the relationships and identities that migration is predicated upon, creates and sustains (Vertovec 2001). These relationships are commonly identified as "a social morphology, as a type of consciousness, as a mode of cultural reproduction, as an avenue of capital, as a site of political engagement, and as a reconstruction of 'place' or locality" (ibid. 1999, p. 447). Cultural geographers, however, have also taken a transnational lens in approaching space, place and the imaginary in transnational communities, beyond geographic material culture (Jackson, Crang, and Dwyer 2004; Ley 2004). These geographic imaginaries challenge the primacy of the nationstate in migration studies, or what Wimmer and Schiller (2002) identify as "methodological nationalism": the "assumption that the nation/state/society is the natural social and political form of the modern world" (p. 301). In this project, a transnational lens provides the avenue to begin investigating how Gambian migrants create and sustain relationships that span across multiple states, and how these relationships may form the basis for alternative narratives that challenge European led-efforts to control the discourse about migration in The Gambia.

While traditional migration studies may regard the Gambia as a state that 'sends' migrants to North America and Europe, and the latter two regions as consisting of states that 'receive' them, transnationalism recognizes that remittances in turn flow from North America to The Gambia, ideas and social norms are exchanged between the two, and labor power moves from The Gambia to North America. So too, 'receiving' states often send 'experts', accompanied by massive sums of money, to 'sending states' to manage migration flows or implement development projects. Of course, these people are never discursively represented as migrants, but they too are a part of a transnational world of mobile people. The sending/receiving dichotomy often situates certain states as actively sending migrants, while others passively receive them. But 'receiving states' actively attempt to control and manage migrant flows, while actively sending tourists, 'experts', aid workers and funding to 'sending states'. Migrants, too, are not passive mobile bodies, permanently leaving one state to settle and integrate into another. Migrants actively shape transnational flows of people, money, ideas, imaginaries and representations. As I will explore, the GNA transnational community not only provides much in 
the way of material benefits to The Gambia, but their experiences and how they represent them in The Gambia may form an alternative narrative to the top-down ones perpetuated by European states and their agents.

\subsection{Research Purpose and Questions}

From these bodies of literature flows a theoretical framework grounded firmly in the mobilities paradigm, utilizing feminist epistemologies to explore how migration is lived and represented, geopolitical perspectives to analyze how powerful actors create and reinforce discourses about migration, and transnational thought to explore the relationships that international migration creates and how migrants may wield these relationships in their attempts to shift dominant narratives. I mobilize this framework towards understanding the relationship between lived experiences and representations of migration in The Gambia, paying close attention to this relationship's embeddedness in dominant narratives produced about Gambian migrants by European states and their agents. The following questions guide the inquiry:

1) How do Gambians experience migration to North America?

2) How do Gambian migrants' experiences become represented in The Gambia?

3) Which actors exercise power to shape and influence dominant narratives about migration in The Gambia?

4) How do Gambian migrants challenge dominant narratives perpetuated by powerful actors?

\section{Outline of the chapters}

In chapter 2, I lay out my research design, methods and positionality. Chapter 3 illustrates how meanings given to migration in the Gambian-North American transnational community (GNA) have shifted over time, according to participants. Chapter 4 delves into how Gambian migrants experience migration to North America. In chapter 5, I analyze how the GNA community is represented in the Kombo (capital city) area of The Gambia. Chapter 6 expands my analysis to include how Gambians who migrate to Europe are represented in the Kombo area, and specifically the role that European actors play in controlling the narratives about Gambian mobility. As I will illustrate, examining the GNA community in relation to narratives about 
migration propagated by humanitarian-development organizations helps reveal the great lengths states of the global North take to shape discourses about migration, and the ways in which migrants may challenge them. 


\section{Chapter 2: Research Design and Methods}

Data for this project was collected during a five-week trip to The Gambia during June and July 2019, followed by three months of fieldwork in the U.S. and Canada. I conducted 33 interviews with individuals living in The Gambia, the U.S. and Canada, engaged in participant observation in all three locations and collected, either online or while in visiting The Gambia, various images, videos and other media pertaining to development interventions and migration policy. All data for this project was collected in accordance with WVU IRB protocol 1903514326. The international fieldwork was made possible through the support of the Explorers' Club Washington Group's Exploration and Field Research Grant. All fieldwork in The Gambia was conducted with the approval of the Gambian National Center for Art and Culture (Research Permit No. 0008759).

\section{Qualitative design}

This project employs a qualitative research design to allow participants to share their own lived experiences, perceptions and opinions (Merriam 1991). While quantitative methods in migration have proved useful in generating demographic models and examining large-grain movements of people, this project examines how individuals experience the process of migration, and how representations of migration relate to migrants' experiences. As Zapata-Barrero and Yalaz (2018) indicate,

qualitative research has a particular importance for migration studies, considering its potential for producing rich, in-depth, and nuanced analysis; allowing for conceptual refinements with higher validity; redefining the existing categories and generating new hypotheses and even theoretical paradigms; exploring complex, conjunctural, multifaceted dimensions of the migration dynamics; and last but not least, being better tuned for understanding the voices of social actors and immigrant groups, especially the ones who lack means of participation and representation in mainstream society and politics ( $\mathrm{p}$. 2-3).

The nature of this project demands methodologies that privilege the particular and the individual, particularly those who are not represented in dominant narratives of migration. This project is well suited for qualitative methodologies that explore migrants' lived experiences in relationship to representations of migration and dominant narratives produced by the state and other powerful actors. 


\subsection{Researcher background and relationship to the project}

As the researcher forms the primary investigative instrument in qualitative research, it is important to understand the researcher's background with the project material, their relationship to the participants, and their hopes for what the project will accomplish (Peshkin 1988). My interest in the issue of migration in The Gambia stems from living there for two years while I was a Peace Corps volunteer (2015-2017). During my first week of training there, before I knew much about The Gambia, we received a lecture from a U.S. embassy consulate worker who informed us (a cohort of 35 volunteers from the U.S.) that migration was a 'major problem' in The Gambia, and that we would likely be approached by Gambian nationals to request help with obtaining a U.S. visa, or funding for their journey to Europe via the 'back way'. While she did not explicitly state that we should discourage them from attempting such journeys, she made explicit that the U.S. embassy in The Gambia had a strict policy of not issuing or assisting any Gambian nationals in obtaining a U.S. visa. Those who wished to obtain one had to make a journey to neighboring Senegal. At the time, this policy seemed logical: I was aware of the 'crisis' of African migration to Europe and assumed that the U.S. would want to avoid a similar situation.

My training as a Peace Corps Volunteer focused primarily on "agricultural capacity building", based on interventionist assumptions that rural farmers in The Gambia are not fully utilizing 'best practices' to take full advantage of the resources available to them. Under our training model, a culturally sensitive community assessment would be done in order to determine which resources were not being fully utilized and what steps must be taken to 'develop capacity' to the point that the community could exploit those resources. Supposedly, through the subsequent generation of wealth, the community would begin to 'lift themselves out of poverty'. While Peace Corps did not explicitly incorporate migration-reduction projects into their framework, I entered service in a rural village with the mindset that such 'capacity-building' could reduce the need for out-migration. I had yet to engage with The Gambia's long history of disenfranchisement at the hands of Europeans, or the contemporary efforts to immobilize Gambians in place.

My naivety quickly faded during my first few months as I came face-to-face with the immense structural issues facing Gambians - particularly the young men who I became friends with. I was struck not only by the requests for help migrating I received, but also the frequency 
with which young men spoke about migrating to Europe or the U.S. They talked about struggling to attempt a dangerous and difficult journey so they could have access to money - particularly Euros or U.S. dollars, which were widely perceived as being more 'powerful' than West African currencies. I approached these conversations using the lens of 'capacity-building'. There was no need for them to go abroad, I thought, they were just under-utilizing their resources here. I recall specifically one conversation with a group of young men who frequently passed the long, hot afternoons by brewing green tea and chatting outside of the 'bitik', or neighborhood corner store. Irritated after listening intently to them talk at length about one friend who had just taken the 'back way' to Italy and was now earning Euros and sending them back to his family, I spoke up: “how can you sit here and spend hours talking about this 'back way' and getting money? You want to abandon your families and your country to go enjoy yourselves in Europe? You should be focusing on the problems here, rather than dreaming about someplace else!" The group responded with laughter at my outburst: "If we had Euros or dollars, we could solve these problems, why don't you give us some American money to make us stop talking about it". While this particular interaction impressed upon me the structural reasons why Gambians migrate, I also began to think more critically about my own role in these social relationships. I too had left behind my family and my country to come live in The Gambia. I too hoped that living abroad would benefit me in some way. Perhaps it would change my perspectives about the world, or even catapult me into a career in the development industry. I was not that different from these young men after all. Except that I was incredibly different from these young men: I could act on my hopes and dreams to travel abroad without fear of death or violence at the hands of police or smugglers; I was not labeled a criminal for crossing international boundaries, or subject to deportation if I was arrested; I was welcomed into The Gambia with open arms, given a Gambian name, and given a house of my own in this small village. The friend these young men spoke so highly of for sending Euros back to their village, as I found out later, was an undocumented person in Italy who had to sleep in public parks and sell drugs to get by. These realizations made me very uncomfortable, but also very curious to delve deeper into how this particular set of social relations came to be.

Thus, this thesis project began to take shape before I ever decided against pursuing a career in the development industry and returned to the U.S. to begin my graduate education. I became interested in talking with young men about migration, about their hopes, dreams and 
challenges. While my status as a white foreigner, a toubab, prevented me from blending in and feeling fully at home in The Gambia, it allowed me to engage in conversations with young men that they would never have with family members or even peers. My mobile status made other people perceive me as a migration 'expert', someone people could come to for advice on obtaining papers or preparing for what Europe or America would be like. As an outsider, people could share certain plans in confidence with me, knowing that I would not reveal them to their parents or friends who might try to stop them or change their mind. These conversations instilled in me a desire to further explore why I had access to certain kinds of mobility, and my friends in The Gambia did not.

\section{1a A multi-sited case study}

Examining transnational mobility requires an attentiveness not just to one particular site, but to many as they relate to the networks transnational migration produces and sustains. Situating this project at just one site would miss a host of phenomena and relationships that span socio-spacetime. As Russell King (2018) argues:

[G]iven the very nature of migration as a human process that traverses spaces and connects two or more places, multi-sitedness in research design is either desirable or inevitable... The 'push' for multi-sited research is not driven just by pure methodological fashion, but rather can be related to important conceptual advances in how (international) migration is theorised and studied. Migration is essentially about border-crossing, transnationalism (and transregionalism, translocalism, etc.) and a range of multi-sited and multi-path mobilities. (p. 41)

In keeping with the necessity to examine transnational migration across spatial contexts, this project consists of fieldwork done in both The Gambia and in North America. While I reject the bifurcation of sites into "sending" and "receiving" contexts, this project does cover both the places of "migrant origin" and "migrant destination", while recognizing that in this case study, extensive circular migration does occur that problematizes this. As peoples' lives increasingly occur across and in spite of state borders (Faist 2009), it becomes additionally important to critically engage with what Wimmer and Glick-Schiller (2002) refer to as 'methodological nationalism', or the "assumption that the nation/state/society is the natural social and political form of the modern world" (p. 301). While I do bound this case study around a sense of "Gambian" national identity, the kinds of transnational relationships this project explores are 
produced through and around state sovereignties. I also recognize the problem with separating Gambian migration from broader West African migration - Gambians' abilities to move across borders often rely on family members who live in Senegal, business partners in Ghana or Guinea, and smugglers in Niger and Libya. My focus on The Gambia is not intended to ignore or downplay the importance of these relationships, but to focus on in one particular setting within which the experiences and representations of migration relate to each other.

Additionally, while this case study focuses largely on the GNA transnational community, I recognize, as do the participants who contributed to this project, that migration between The Gambia and North America does not exist in a vacuum - it cannot be isolated from the broader context of Gambian migration. This is especially true as European states' efforts to control representations of Gambian migration intensify. Because of this, the case study also includes the discursive space that European developmental bordering practices creates in The Gambia.

\subsection{Methods}

This project is grounded in 33 unstructured and semi-structured interviews that took place in The Gambia and North America from June to November 2019. The interview protocol, approved by WVU's IRB board, was designed to maximize participant confidentiality, particularly in the case that a participant did not have legal status where they lived. I received a waiver of consent form for this project so as to leave no paper trail of who I had spoken to. I did not record any participant names unless they requested to have their name associated with their stories. Per IRB protocol, I assigned an alpha-numeric code that I was sure to remember to each participant, but kept no master code list to link a code to a particular person.

\section{2a Participant selection}

From my theoretical framework, a number of criteria emerged from which to develop a sampling strategy. These consisted of: 1) the need to examine migration as it is both experienced and represented; 2) the need to account for the diversity of experience in the case study; 3) the need to protect participants' identities; and 4) the need for significant flexibility in sampling as different themes emerged during fieldwork. From these criteria, I developed a sampling strategy that incorporates elements from theoretical sampling (Glaser and Strauss 1967) and snowball sampling (Creswell and Creswell 2018). I began by identifying different themes that I wanted to 
explore through fieldwork and different groups of people with which I could explore them but did not create a conclusive list of the kinds of people I would speak to or develop any kind of probability or statistical sample. Setting out on this project, I decided to primarily interview people who had migrated from The Gambia to North America. However, as the project progressed, it became clear that I needed to speak to migrants' family members in order to understand how the experiences of migration translated from North America back to The Gambia. Thus, I identified that the primary participants in this project would be: 1) Gambians who have migrated to the U.S. and returned home, 2) Gambians who are planning to migrate to the U.S., or expressed interest in migrating to the U.S., but due to challenges now plan to go elsewhere, and 3 family members of migrants who currently reside in the U.S. Upon arrival in The Gambia, I began reconnecting with former neighbors and co-workers from my time living in The Gambia to discuss the project and get their guidance as to how to best go about identifying migrants. Some of these individuals had been migrants themselves, or had a family member abroad, and became participants. Others connected me to others I could speak to. These individuals formed the preliminary snowball sample and then subsequently connected me to other individuals in The Gambia or North America, effectively 'growing' the sample. While in The Gambia, I also spoke with two “expert” participants (Flick 1998) who had knowledge of migration policy and development projects that target potential migrants. These participants both worked for non-state actors with some stake in migration policy - one for a religious charity, the other for the IOM. Recruitment in the U.S. and Canada was much more difficult because many Gambians in North America may have no legal status or may be on temporary visas that will expire in the future and thus fear to be discovered by immigration authorities. All of the Gambians I spoke with living in the U.S. and Canada were friends from my time as a PCV who migrated within the past two years.

Additionally, upon arrival in The Gambia, I began looking for someone who could help me as a research assistant. Through a mutual friend, I got in contact with a man named Ello Kandeh, who currently studies International Development at the University of The Gambia and also works as a primary school teacher. Ello agreed to help, and we agreed that in exchange for his assistance, I would pay him a per-diem and provide food and transportation costs for the days he worked. At the conclusion of my five-week visit to The Gambia, we agreed that I would then help his family purchase some building supplies to add on a small kitchen out-building to their 
compound. Ello helped to facilitate contact with a number of participants, and then assisted in several interviews. After conducting a practice interview together, where Ello demonstrated his familiarity and comfort with the interview process, he conducted some interviews by himself in cases when a participant was nervous about revealing their identity to me. Ello also played a crucial role in explaining the nature of the project to participants in ways that I could not. Without Ello's assistance, I would not have been able to conduct as many interviews as I did, nor could I have put some participants at ease concerning the confidentiality of their identity.

\section{2b Interviews}

Over the course of approximately 6 months, I conducted a total of thirty-three (33) interviews. Twenty-eight (28) of these were with people connected to the GNA community (either migrants themselves or migrants' families). I conducted an additional three interviews with migrants who had been deported from Libya, and an additional two interviews with employees of charities and NGOs. All interviewees are 'Gambian', in that they were either born in The Gambia, or have adopted The Gambia as their home. 11 are women, and 14 are men. 3 are Christian, one agnostic, and the rest who specified their beliefs are Muslim. The participants comprise a range of ages, with: 7 in their 20s; 8 in their 30s; 2 in their 40s; 7 in their 50s; and 1 in the 60s. 8 participants specifically requested that I provide no information about their identity, or any quotes associated with them in this manuscript. Paraphrased information from these 8 participants may be incorporated into my discussion without any explicit mention of who it came from.

I did not go into the interview process with the intention of reaching a specific sample size, as Karolina Barglowski (2018) indicates that it is "not the size of the sample that is relevant for the quality of the results, but much more that it covers the diversity and differences in the empirical field, which usually happens through comparisons and contrasts" (p. 157). Instead, I continued conducting interviews until my results became 'theoretically saturated' (Corbin and Strauss 1990), or I reached a point where additional interviews would not provide "relevant results to the themes, concepts, codes or theory" (Barglowski 2018, p. 158) . In this case study, I quickly reached saturation of migrants' family members (non-migrants) while doing interviews in The Gambia and switched to only doing interviews with migrants themselves after the first two weeks of my visit. 
As much as possible, I conducted interviews in a manner so as to place the participant at ease in a comfortable, familiar setting. Once a participant agreed to participate in the study, I asked them to select a time and a place for the interview. In The Gambia, all interviews took place in person. The majority took place at a participant's home in a quiet space where they could speak freely. A few took place at a participant's place of work, and two took place in the residence where I stayed. Interviews in North America took place either at a participant's residence or over the phone.

I used both semi-structured and unstructured interview formats in order to keep the "research agenda open-ended and allow respondents to hint at possibly omitted areas of inquiry" (Fedyuk and Zentai 2018, p. 176) Which format I used depended on the participant and the nature of our conversation. As much as possible, I followed an interview guide (see Appendix A). However, the semi-structured format was not appropriate for some interviewees, who were either uncomfortable with a 'formal' interview process and preferred to frame the interview as a 'social call', or others who wanted to use the interview as an opportunity to tell their story without my interference. For participants comfortable doing a more standard interview, I asked questions from the interview guide, but allowed the participant leeway to shape the conversation. For those uncomfortable with the semi-structured interview format, I made a 'social call' to their home, where we talked for several hours without use of the interview guide, although I made sure that they covered the main themes present in the guide. If Ello was present for an interview, he often added in his own questions. Each interview began with a review of my IRB protocol and the participant was asked to give verbal consent to be interviewed and audio-recorded. Most participants consented to an audio recording, but for those who declined, I took hand notes during the conversation. Most participants also requested anonymity, with a few exceptions. Some interviews were short, less than 15 minutes, but most lasted at least 30-45 minutes. For those that took the form of an extended social call, I did not record the entire day of interactions, but turned on the recorder for certain conversations. I took notes for each interview even if the interview was audio recorded.

The Gambia is a multi-lingual nation where English is the official language and Mandinka, Wolof, Pulaar, Joola and Sarahule are the main national languages. While I am proficient in Pulaar and Wolof from my time as a Peace Corps Volunteer, I conducted the vast majority of interviews in English primarily, with the conversation occasionally shifting to Wolof, 
Fula or Mandinka (Ello is fluent in Mandinka). I conducted one interview in Pulaar, which I then translated to English and asked a native-speaker of Pulaar to check for accuracy.

I also used both semi- and un-structured interviews for interviews with migrants in North America. Those conducted over the phone were done using the interview guide, while those done in person took the 'social call', unstructured format. All interviews in North America were primarily conducted in English. At the outset, I did not ask participants any questions pertaining to their immigration status, but some participants freely offered this information. While I did not originally intend to record any information about a participant's legal status, it became clear over the course of the project that legal status was an important element in constructing my analysis of lived experience and representation. I began to record information pertaining to legal status with the participant's permission. In this document, and in any future publications, I use a pseudonym for each participant unless they specified that they would like their name included with their information.

\section{2c Participant Observation}

Equally important to conducting interviews was my time spent socializing and participating in everyday life in The Gambia during my visit, and with migrant communities in North America. In the ethnographic tradition, participant observation is an important method with which to build rapport in a community, strengthen relationships and learn information that does not come out in direct interviews (Creswell 1998). Participant observation provided the means through which I assumed an "embodied and extended presence in... [s]ocial life as it is being lived, rather than only as it as reported by informants (often in ephemeral, artificial or ad hoc settings)" (Boccagni and Schrooten 2018, p. 212). While participant observation is frequently mobilized as a means for ethnographers to gain access to and the trust of a particular community, for me, it was a means to maintain relationships with individuals I had not seen for nearly two years, and to build outward from my existing social network as part of my sampling strategy. Participant observation, for me, involved long social visits often lasting for hours, eating meals with participants' extended families, and brewing green tea late into the night. This allowed me to explore different topics in conversation that helped to better understand themes that arose in interviews. I kept a journal while in The Gambia to help me make sense of these themes as they came up, and coded notes from my journal as part of my later analysis. 


\section{2d Discourse Analysis}

To understand the ways migration is represented in The Gambia, I studied what (van Dijk 2018) refers to as 'migration discourse', which refers to a large class of discourses about migrants and migration. As van Dijk recommends, I determined exactly which genres of discourse I intended to study during the project, but also kept my eyes open to other forms of discourse that could advance the analysis. Over the course of fieldwork in The Gambia and North America, I collected a combination of: 1) media discourse, including news reports, public debates, interviews and internet coverage of migration in The Gambia; 2) political discourse, particularly politicians' speeches about migration; 3) administrative discourse, specifically the policies and language of administrators in the development industry; and 4) Internet discourse, or the language used on websites, blogs and press-releases of humanitarian organizations/development practitioners (van Dijk 2018). In the course of collecting and analyzing these different types of migration discourse, I continually asked 'who is producing the discourse? Which power structures is the discourse embedded in? How far removed is the discourse from the lived experiences of Gambian migrants?' The discourse-containing documents I collected largely consist of pictures of billboards about migration, news releases and interviews with migration 'experts' or government officials in The Gambia, video blogs (vlogs) from European humanitarian actors who visited The Gambia to document development interventions related to migration, and press-releases from European NGOs and humanitarian organizations.

The interviews I conducted and the conversations I had during participant observation also form a kind of 'everyday', interpersonal discourse. My analysis attempted to integrate this everyday discourse with the different genres that I discussed above. In the course of attempting to define which actors exercised power over discourse, I identified the need to distinguish between dominant and alternative narratives. For the purposes of this project, I defined a dominant narrative as one which, either through saturation or repetition, I could identify as the primary discourse through which people engaged with a topic. The alternative narrative, by extension, I identified as a discourse that either explicitly or implicitly opposed a dominant one people always used alternative narratives to oppose dominant ones.

\section{2e Coding and analysis}


I began transcribing interviews during the Gambian stage of my fieldwork and continued to do so upon return to the U.S. and while conducting interviews in North America. After the completion of fieldwork, I began to code the interviews, notes from participant observation and the discourse-containing documents. Using NVivo 12 software, I assembled all of the interview transcripts, notes and documents and began with an in vivo analysis - using participants' own words - to understand how the language participants used related to broader themes. This involved a 'word frequency' analysis of the interviews and documents to determine what language the various actors used to discuss migration (see Appendix B.1). I did not use my own field notes for the word frequency analysis so that I could focus exclusively on how both participants talked about migration and how the documents represented migration. From the word frequency analysis, I began to identify initial themes, or in vivo codes (see Appendix B.2). From this list, I did a first round of coding on transcripts, documents and my notes. After the preliminary coding, I re-read all transcripts, documents and notes a second time to identify any emergent themes that I had missed in the in vivo analysis. I then created a hybrid list including both in vivo codes and thematic codes and coded all transcripts, documents and notes a second time (see Appendix B.3). After the second coding process, I began to write up the results. During the writing process, I performed a few "member checking" conversations (Caretta 2016) with participants whose interviews raised especially sensitive or political themes, to ensure that they were supportive of my intent to publish their words in the context I wrote them. This process forced me to shift my analysis of NGOs in The Gambia to an extent in order to protect certain participants.

\subsection{Limitations}

This thesis does not attempt to provide a full account of migration in The Gambia - it is limited in many ways - spatially, temporally and by my positionality as a researcher. Specifically lacking in this manuscript are the voices of Gambian migrants who traveled to Europe. This is partially by design, but also because I did not have the time or resources to conduct interviews in Europe. This project also skews heavily towards people who are currently living in The Gambia. It was exceedingly difficult to establish connections with migrants living in North America particularly the U.S. - due fears throughout the broader migrant community of ICE 
investigations. The 7 interviews I conducted with people living in North America were only possible because I had an existing connection from my time living in The Gambia.

Sparingly, throughout this manuscript, I hint at the intersections of gender with migrants' experiences. This is not to dismiss the importance of gendered dynamics within the case study, or the broader Gambian migrant community. Indeed, other researchers have paid particular importance to gender in West African migrant communities - illustrating how men's migration is embedded in historic notions of masculinity and mobility, while women's often results in shifting gender roles (Wong 2006; Babou 2008; Prothmann 2018). In this study, however, the salience of the intersections between race, class and legal status drove the analysis. My position as a man, too, influenced how I asked questions, analyzed data, and what participants were willing to share with me. I intentionally did not broach the topic of sexuality with participants asking questions or collecting data pertaining to this could have proved problematic for me, and dangerous for participants due to the sensitive nature of sexuality in The Gambia.

Finally, my position as an outsider familiar with The Gambia provided many benefits but limited the project in some ways. I had greater access to 'expert' or upper-class participants, but less access to more precarious participants than a Gambian researcher would. This was partially mitigated through Ello's assistance in contacting participants and conducting interviews without me. This did, however, skew the participants to mainly include those who were comfortable speaking with a foreign, white researcher. As I will discuss in the conclusion, this case study is a starting point that I hope others will build off of to expand my limited analysis. 


\section{Chapter 3. Situating the case study: 'Waves' of migration}

People living in Niumi, on the north bank of the Gambia River, have been involved in the exchange of goods and ideas with people some distance away for as long as there is any record. From the eighth century CE, if not earlier, western Africa was connected to the commercial complex of the central part of Eurasia through the trans-Saharan trade, and Niumi was part of a network of considerable scope and sophistication that was tied to that exchange.

DR Wright. 2010, p. 33

The ways that movement is experienced and represented change with time. As Tim Cresswell (2006) writes, "ideas about, and practices of mobility have been historically variable. The movement of people has been central to the construction of worldviews in wildly different ways" (p. 21). Mobility in The Gambia must, too, be understood as part of historical patterns of movement in West Africa. Historians of West Africa have detailed the different ways that meaning has been given to movement in West Africa: from movement as empire building and conquest (de Villiers and Hirtle 1997), to movement as economic enterprise and ethnic formation (Wright 1985, 2010), to movement as religious and scholarly work (Babou 2002, 2008). While detailing the myriad of wildly variable ideologies of mobility that have given meaning to movement throughout West Africa is far beyond the scope of this thesis, a brief illustration of the different ways that movement between The Gambia and North America mobility has been given meaning will help to situate my findings and discussion. Here, I rely primarily on interviews with older participants who detailed to me, in their words, several "waves" of Gambian migration to North America. While 'waves' and 'floods', among other hydraulic metaphors, are often mobilized to situate migrants as a threat or 'invasion' (Gorman 2019), Wright (1985), notes that the notion of 'waves' may help to explain the way that myriads of lived experiences coalesce into dominant representations of movement, and the way that these representations change over time. Throughout this chapter, I use participants' language of 'wave of Gambian migration' to illustrate the shifts in the way that people give meaning to movement. Discussing these histories as 'waves of migration' does not mean that all lived experiences within a given time-frame look alike, only that there are a few distinct trends in how participants thought about migration to North America during the past forty years.

Human movement between The Gambia and North America is by no means a new phenomenon. The original Gambian to arrive in North America came on ships, borne across the 
Atlantic against their will as part of the slave trade. Peoples from what is now The Gambia and others from many other parts of Africa were held in chattel slavery in the Americas for centuries, their labor exploited on countless plantations. People from the Senegambia region played a crucial role in establishing the rice plantations of the Carolinas, not just through labor, but using strains of rice from The Gambia, and provided the knowledge and skill necessary to exploit the estuarine landscapes and produce rice (Carney 2009). This section, however, focuses on migration between post-independence (1965) migration from The Gambia. The participants I spoke with shared stories covering four decades of migration between the Gambia and North America, and their collective experiences shed light on the changing experiences of those who undertook the journey, and the changing ways that journey is represented and politicized.

Multiple participants brought up the notion that since the 1980 s, there had been several "waves of migration" between The Gambia and the U.S., characterized by certain groups of people who migrate and particular social, economic and political situations that lead these groups to migrate. Suleiman , a Gambian entrepreneur and philanthropist indicated that the 'first wave' of Gambian migration to the U.S. was characterized by vendors of African arts, woodcarvings and fabrics. This first wave of migrants, he argued, mostly traveled to the U.S. on temporary visas to sell their wares in batches before returning to West Africa to purchase or make more. These vendors, mostly men, he noted, were highly mobile, engaging in extensive circular migration between cities on the East Coast of the U.S., The Gambia, and other West African nations, particularly Nigeria, Côte D'Ivoire, Ghana and Guinea. As Suleiman, a fabric salesman in the 1980s, noted:

I could say during this period I used to go and come, because as soon as these bolts (of fabric) finished, I come to [The Gambia] here to purchase more, and I'll send it again. Later the business was expanded, and I went to Nigeria. I was buying it from Nigeria and sending to the U.S. Then I also went to Benin, there's a factory there... I was producing my own fabric from that factory. And also Nigeria, I went to Ghana. So that one they have a factory too, I was buying from there. And Senegal here. Then in the republic of Benin, I then had some tailors who were making the garments for us, then I export all these to [the U.S.].

Many of these fabric and craft vendors, like Suleiman, were ethnic Soninke or Sarahules, groups who have a long history as traders, bankers and businessmen. Gambian Sarahules had already established significant business enterprises by this time throughout Europe, North and West Africa. This 'first wave' of Gambian migration to the U.S. simply represented an expansion of 
these trade networks to North America. Suleiman ' description highlights the transnational nature of these business networks, in that his business took place across several different West African states at once. Suleiman also noted, that at this time, it was relatively simple to get a temporary visa to the United States, and that there were few Gambians there in the early 1990s. While he indicated that there was a community of Gambians in New York City at the time,

When I went to United States first, the people from here were not that much, so when I apply in Abdijan [Cote'd Ivoire] in those days, there were fewer people. Abdijan is a big city, and the Gambians in Abidjan, in those days, none of them ever tried to get a visa. So, they don't see [the U.S.] as a money-making place at that time. Only the people who were selling the African arts used to go. They are now, when people started sending money from there, said I'm working in America, this money is here. Then the whole continent opened their hearts to United States. I believe as the number has increased so much, and then the government of the United States changed the policies.

Yeero, an older male participant, confirmed the relative ease of receiving a visa during this period, and added that this 'first wave' also included Gambians hoping to receive a bachelors' degree in the U.S. before returning home. In 1988, he notes, he received a student visa to go to the U.S. after a simple interview at the U.S. embassy in The Gambia. It is notable that he received a visa from this location, because at a certain point, the Gambian U.S. embassy ceased offering visa interviews at that location, meaning that any Gambians who needed to travel to the U.S. must instead travel to neighboring Senegal for a visa. One participant, Kebbah, who applied for a visa in 1983 was turned down when he applied for a one-year visa. When he re-applied again for a shorter period of time, he was turned down again for already having applied. Saraldu, another older male participant, was rejected for a student visa in 1992, as he reports, because he did not have enough savings in The Gambia. While most participants indicated that visas were easier to obtain to the U.S. at this time, Kebbah and Saraldu's cases show that the ability to obtain a visa was, even then, highly classed. Yeero and Suleiman both came from wealthy families in the capital with savings, but Kebbah and Saraldu, not coming from the upper echelons of Gambian society, were ineligible.

At a certain point, Gambian migration shifted from businessmen and students whose patterns followed more circular migration style, to Gambians looking to go settle permanently in the U.S. Suleiman notes that in the 1990s, a 'second wave' of migration formed, where Gambians began attempting to travel to the U.S. and other destinations to find work, settle and start families. Three younger participants confirmed this: Saidy and Omar, two university 
students, and Bakary, a recent graduate from university, were all raised in the U.S. before returning to The Gambia to study or work. They each noted that their parents were able to secure work visas and move to the U.S. in the 1990s.

Participants indicated that in the early 2000s, it became increasingly difficult to secure a visa to the United States. Most participants pointed to the September 11 ${ }^{\text {th }}, 2001$ attacks on the United States as the point when this shift occurred. Caroline Nagel (2016), writing in the context of refugee resettlement, points to the attacks on New York City as the catalyst behind a shift in U.S. migration policy. The rise in Islamophobia resulting from the attacks not only led to more restrictive policies for migrants from predominantly Muslim states, but also increasingly politicized the presence of Muslim migrants. Younger participants found it much more difficult than their parents' generation to travel to the U.S. Bakary mentioned that while his parents had received their visas easily in the 1990s, when he attempted to reunite with them in 2003, his application was denied several times despite his parents' legal status in the U.S. At some point in the early 2000s, the U.S. Embassy in The Gambia ceased doing visa interviews, forcing participants to instead travel to Dakar for visas. This added the time and expense of an eight-hour trip and overnight stay in Dakar to the already expensive process. While a class distinction existed prior to this time, it became increasingly difficult for even wealthy Gambians to travel abroad. Sainaba, an older Gambian woman from a wealthy family, who routinely traveled to visit family in the U.S. mentioned that after the changes in visa policies, it became more difficult for her to secure a tourist visa even to visit her family in the U.S. for two weeks.

Since 2001, it has become extremely difficult for most Gambians to travel to the United States. Many participants note that the burden of proof that applicants will come back to The Gambia, and not overstay visas, has been heightened to the point that only the wealthiest Gambians are now eligible to travel to North America.

\section{Shifting trajectories}

While Gambians have also traveled to Canada for many years, including Yeero, who spent some time in Canada in the early 1990s, participants note that as the U.S. immigration policies became increasingly strict, many migrants turned to the possibility of going to school or finding work in Canada. Abulie, who went to Canada for his undergraduate education, elaborated on the reasons he chose Canada over the U.S.: 
I was afraid of American guns, America was not an option for me...there is nothing that's in the dark anymore. Everything is everywhere. We can see. We know we are not welcome in the United States anymore. We know we will do United States if we have to. But again, this doesn't represent my view of Americans. But it represents the policies of the leadership currently. And we also understand that it can change in the next few years or so. But just to tell you the truth, that's how we feel. We feel we are unwelcome in the States anymore.

While some cited the social and political climate in the United States others felt that Canada was an all-around better place to live and work. Salimatou and Jeneba, young women who recently graduated from university in The Gambia, noted that they hoped to go abroad for their master's degrees:

Salimatou: You know for me, if I have my choice, I will pick Canada over America for a master's.

Martin: Why is that?

Salimatou: The universities are better there.

Jeneba: And the cities are nicer. That place now, everyone wants to go to Canada over U.S.

Salimatou: You know, in Canada the people are nicer than Americans. And there you can have your papers in order. There's no overstaying the visa and then getting deported. Once you have a job, you can become a citizen. Not like in America.

Zainaba also decided to study in Canada over the U.S. due to the wider availability of scholarships and support for international students there. Canada's easier access to Permanent Residency (PR) has made it a more attractive destination for Gambian families looking to work or study abroad. While Gambians in the U.S. often overstay tourist or student visas due to the unavailability of legal paths towards citizenship, Gambians in Canada can expect to gain PR status within a few months of arrival. As Abulie summarized:

For safety, for love, for the welcoming nature, for the opportunity, for the consistency in the policy of Canadians. I think that is the biggest pull that attracts Gambians to Canada. It sets an example. If you study in Canada, if you have a truly premier program in Canada, there is a clear pathway to be a Canadian citizen... So you know in Canada, if you work by the rules, if you study hard, if you work hard, there's a pathway for you to belong. But I have friends in the U.S. who have been there for over 10 years and they still don't have their citizenship.

Since the 1980s representations of migration between The Gambia and North America have gone through a number of 'waves'. From short-term patterns of circular migration by traders and students, to longer-term settlement by families hoping for work, to more restrictive policies, to a shift in interest from the U.S. to Canada due to changing social and political realities. Today, 
many Gambians recognize that moving to the U.S. is but a dream, and set their sights on other states, such as Canada, where they can study and find work. The classed-distinctions about which migrants can move to North America corresponds with other work in migration studies from the early 2000's, documenting that visa restrictions increasingly make 'legal' migration only available to wealthy migrants (Carling 2002). These different 'waves of migration' also begin to illustrate the different ways that both Gambians and North Americans imagine and represent migration. While ideas about Gambian migration in the 1980s and 90s may have complemented images of an increasingly borderless world, these ideas shifted in conjunction with rising Islamophobia to situate Gambian migrants as 'security threat' or 'other' in the U.S. Their increasing politicization in the U.S. may be creating a new 'wave' of migration that situates Canada as a greener pasture than the U.S. for migrants. 


\section{Chapter 4. 'Making it': Imagined places, embodied experiences}

Movement is rarely just movement; it carries with it the burden of meaning and it is this meaning that jumps scales.

Cresswell (2006, p. 6-7)

The language people use to describe movement is a first step towards unraveling the multistranded relationships that associate meaning with movement. As I began to engage with these relationships in the context of migration in The Gambia, I was beset by a dizzying array of terms and words from participants, the state, scholarly literature, and migration 'experts'. From amidst the vast tapestry of language that people used, one phrase in particular emerged that began to frame the way I viewed experiences and representations of migration: 'making it'. 'Making it' was used by people to talk about migration from many, often contradictory angles. Migrants used it to talk about their experiences, migrants' families used it to talk about their increased status from having a relative abroad, and a variety of state and non-state actors used it in attempts to perpetuate top-down narratives about Gambian migrants. Over the next three chapters, I will argue that 'making it' is a contested term whose meaning is being fought over by a range of actors: migrants, their families, states and non-state actors. To begin to unravel the complexities and contradictions inherent in this term, and different actors' investments in controlling it, I take as a starting point the lived experiences of migrants: how they conceive of 'making it', and the stories of their journeys towards this goal.

\section{1 'Making it' and migration}

In the course of asking people about their "experience of migrating" the topic of why they left The Gambia invariably came up. Most cited the need for money, the desire to work or the hopes of a good education. Some specifically noted the need for "foreign money" or "international money", or "money with power", referring to dollars, pounds and euros. These reasons given were often differentiated by a participant's class status, with those from higher class most often migrating for an education, while those of a lower class looking for a way to make money. Some hoped to stay abroad permanently, others hoped to return to The Gambia after a period of years abroad. Regardless, all participants indicated that they or their family member needed to migrate in order to accomplish something they could not do without leaving The Gambia. Many used the 
term 'making it' to refer to what they wanted to do, or what others were doing abroad. As I homed in on this term and learned it's equivalent in Wolof - "tekki" - I began to hear it spoken in passing on the street, used especially to refer to someone who is earning money or leaving The Gambia. It was also used to refer to why someone would not migrate (munna tekki fii - I can make it here in The Gambia). In a sense, 'making it' is a way to describe succeeding or becoming successful, but these visions of success do not all look the same.

Participants expressed a myriad of different possibilities in which they or a family member would 'make it'. Bakary, a young man who grew up in The Gambia, then moved to the U.S. for school and is now back in The Gambia used the term to describe his friends currently living abroad: “they're out there, they're making it. They're sending money home for their families to build nice houses." In this instance, Bakary refers to people who are currently living abroad and supporting their family at home. The act of being abroad and being successful, here, is 'making it'. Penda, who currently lives in The Gambia, has a husband living in Canada. She hopes to join him there in order to pursue a master's degree before coming home to The Gambia: "After learning, I would like to come back and settle here. It's my main dream... if we had that support, we would work together. I think he could make it here”. In this instance, Penda uses the word 'support' to refer to the financial and social benefits of having lived abroad in Canada, materializing as capital to start a business, prestige from having lived abroad, and a foreign diploma, which would help the two of them obtain white-collar jobs in The Gambia. 'Making it', for Penda, did not explicitly refer to the act of migrating abroad, or the state of living abroad but the benefits she and her husband would have upon their return to The Gambia. These benefits, however, were still defined in relation to the process of migration.

Sarjo, who lives in Canada with her husband Saikou, had different ideas about what 'making it' meant for her family:

"We are very happy to be here in Canada right now, but we want to go back to The Gambia after we save some money and ensure that the children have a proper education. The idea is to see if we can have a house here, and one in The Gambia so that we can travel back and forth."

For Sarjo, 'making it' was not necessarily constrained to a particular place, but a more, transnational notion - spanning the borders of both The Gambia and Canada - enabling her and her family to have lives in both places at once. 
Leaving The Gambia was not the only way that people talked about 'making it'. For some, staying at home and working using the skills and resources available to them was the best way to 'make it'. Kebbah, an older Gambian beekeeper, indicated that:

[Y] es you can come to America and come home, would be very normal. But lots of times many people try to go and settle there, because they want to go and look for jobs there. I know the kind of job I want to do can only be done here. Because the natural resources are here... I have a good piece of land... I know that I can make it in Africa. I can work. And I think that one day, one day. In my dreams I think I can go to America for a holiday, like they are coming here for a holiday.

While Kebbah felt that his resources were adequate to 'make it' while living in The Gambia, his dreams of 'making it' involved the ability to travel abroad and to experience international mobility as a tourist rather than as a migrant. Kebbah, due to his access to information about the U.S. or Europe, understood that as a migrant, he would largely be confined to working in the service industries as a precarious person. Others, however, imagined North America not as a place where they would struggle to get by, but as a place where they could go to 'make it'. For many migrants, 'making it' became the defining reason behind leaving The Gambia, and representations of North America in television, media, and other migrants' stories became the basis for geographic imaginaries of North America as a place where 'making it' would be easy.

\subsection{Imagining greener pastures and greater successes}

Each participant I spoke with related to me some kind of impetus for leaving The Gambia and traveling. As Omar, a university student in The Gambia summarized "Gambians migrate, or any immigrant migrates because of, you can say, a better life". While it may appear logical to reduce desires for a 'better life' to simple economic factors, as did the New Economics of Labor Migration literature did (Taylor 1999), and many contemporary policy thinkers continue to do (Lavenex and Kunz 2008; Janko 2012), this case study reveals that economic calculations are but one reason that migrants seek to travel. Of key importance here are the geographic imaginaries of states of the global North, especially the United States, as places where it is easier for migrants to 'make it'. As participants indicated, these imaginaries of other places played an important role in not only their desire to travel abroad, but their desire for a 'better life', or to 'make it'. As Noel Salazar (2011) notes:

In the cultural logics of migration, imaginaries play a predominant role in envisioning both the green pastures and the (often mythologized) memory of the homeland. Migration 
is as much about these imaginaries as it is about the actual physical movement from one locality to another and back. The images and ideas of other (read: better) possible places to live - often misrepresented through popular media - circulate in a very unequal global space and are ultimately filtered through migrants' personal aspirations (p. 386-387)

Representations, often highly visual, of North America as a place where people can 'make it' and live the easy life feature predominantly in migrants' imaginations. As many participants encountered, however, these imaginaries did not necessarily hold up once they arrived.

\section{2a You have to see it to believe it}

For many participants arriving in North America was a highly visual process that brought into conflict geographic imaginaries of North America with their own embodied experiences.

Expectations of North America relying heavily on visual representations of success and the easy life were contradicted by migrants' own eyes - their own visions of North America. These experiences, for many, were quite memorable. Bakary, who arrived in the U.S. around age 15, remembers arriving into New York at night:

I landed in New York. I was really surprised, I was like this is beautiful, cause they had the limousine taxi kind of thing at JFK. And it was at night. Everything was lit up, nice, beautiful. And I'm like... this is exactly what I've seen on TV. But then during the daytime, my uncle... took us around, and I'm like. Ok, this is not the America that I thought would be here. Cause it was different. I'm like - ok, it's normal. It's a different place, different environment, different people, but I was like... well there's nothing like a big, big surprise.

The visions of New York City in television and film Bakary had previously seen almost override the subjective, embodied vision of arrival to the U.S., replacing embodied experience with narratives generated by popular media. But the clear vision of daylight revealed New York for what it was, a complex city full of not just beauty and glamor, but the banalities of everyday life that contrast with its representations in media. Other participants experienced similar visual processes that introduced them to the realities of North America, in ways that both inspired awe, and made participants realize that they were "not in The Gambia anymore", as Abulie shared:

Yea, a friend had said, wow, this is like toubab (white-foreigner) magic. It was my first time climbing an escalator. It was my first time having automated doors. Toilets flushing themselves. Having taps opening all by themselves. That was like magic. Like how you have motion sensors... It was a crazy day. It was really an eye-opener for me. Even 
though I thought I saw it all at the time [in television], the experience of course was really interesting.

For Abulie, the "magic" associated with technologies of North America came into focus, not as other-worldly images this time, but as banal realities that he would now experience on a daily basis. Samba had realizations of a different sort during his first few days in the U.S.:

I saw a house with all of the furniture and belongings sitting outside on the street, I said to my wife, 'oh, they must be moving'. She said 'Welcome to the U.S. That's an eviction'. We don't do things like that here in Gambia, if someone doesn't pay rent, it can take years of negotiating before you ever force someone out of the home, and even then, you would allow them to leave with their dignity intact

Samba's encounter with the realities of poverty and inequality in the U.S. flies in the face of popular representations of North America in The Gambia as a place where it is easy to find money and get ahead in life. These disconnects between the expectations of what life in North America is like and the experience of actually arriving begins to illustrate the relationship between representations and lived experiences. For most Gambians, representations of the U.S. come from news media, television and movies. While relatives may tell stories or give advice, representations in the media depict North America in ways that are often not reflected upon actual arrival. Bakary confirmed the importance of first-hand experience to fully situate knowledge of a place, noting that:

I had a lot of friends who used to travel. Some of my family used to travel too. They used to tell you, like you want to go to the US? Well it's not the same as you think it is. I'm like, ok. So I've been getting those types of information, that stuff, like that when you go abroad it's gonna be different. Being here in The Gambia, you have to go and see it before you believe it.

These experiences of arrival begin to illustrate how representations and lived experiences are linked. Perhaps Abulie would not have wanted to travel to North America in the first place had he not seen glamorous images of cities and technology on his television in The Gambia. The often idealized and romanticized imaginaries of 'making it' in North America came into conflict with the migrants' actual experiences of living abroad. Many participants, shortly after arriving, began to encounter difficulties that stood in the way of their success. While moving to a new place and entering into a foreign culture is difficult for anyone, Gambian migrants' experiences were shaped by how they entered into unfamiliar race, class, gender and legal formations. 


\subsection{What 'making it' looks like}

After arriving to North America, participants began acting on their plans to 'make it'. While many experienced shock at the differences between their expectations and the reality they arrived to, participants now faced the long and arduous task of adapting to the culture and norms of North America in a way that would bring them success. Much of this process of adaptation involved the bare fact that, in the process of moving into a different socio-cultural time-space, participants' identities had to be negotiated amidst a new and shifting landscape - especially with regards to race, legal status, class and even gender. They entered unfamiliar waters in regard to identity and had to quickly adapt in ways that would allow them to 'make it' in North America.

In this section, I draw heavily on intersectional theory to analyze not only the way that identities intersect (Crenshaw 1991), but how, in the case of migrants, identities morph and intersect in new ways as they enter unfamiliar socio-spaces. Mahler, Chaudhuri, and Patil (2015) specifically charge researchers examining transnational communities to maintain an attention to the ways that identities morph and intersect over different scales, and through transnational mobility. Here, I will draw specific attention to the categories of 'race', 'class', 'gender' and 'legal status' to illustrate not only how migrants adapted to changing categories of identity in the process of migration, but how in turn, migrants then shifted these categories through their own mobility and attempts to 'make it'.

\section{3a 'I didn't know what hard work was until I came here'}

Kebbah, in the hopes of advancing his career as a beekeeper in The Gambia, wanted to go to the United States to take a five-month training course with a beekeeping association on the East Coast. He attempted to get a tourist visa in 1982 and after paying the application fee of 3,000 dalasis at the time, he was rejected because he applied for too long a period of time. Two years later, he applied again, paying the same fee, but for a 90-day tourist visa. This time he was rejected because he had already applied once. Kebbah hired a consultant to help him improve his chances of receiving a visa, paying the consultant 500 dalasis for a two-hour appointment. The consultant advised arranging a short, one-week trip to Morocco from which he would return to The Gambia to demonstrate to the U.S. embassy that he would "come back" after his training in the U.S. At this point, Kebbah gave up his dream of travelling abroad because arranging the trip to Morocco would have depleted his entire extended family's savings. 
Saraldu, who in 1992 graduated from high school in The Gambia, also wanted to go to the U.S. to receive a bachelor's degree, since there was no university in The Gambia at the time. He had an uncle living in the U.S. who agreed to provide housing and to help pay his tuition, and he thought he had a reasonable chance of receiving the visa. During the application process, however, the immigration officer asked to see a copy of Saraldu's family's bank statement. Saraldu's family, coming from a rural background, kept their wealth in livestock and in land, and had no bank account. Saraldu was rejected on the spot.

These two stories illustrate not only the convoluted process of obtaining a visa to the U.S., even in the 1980s and 1990s, a time during which participants noted visas were easier to obtain, but they also indicate the degree and type of wealth Gambians are expected to have as a precondition for migrating to North America. Of those I spoke with who actually traveled to North America, all came from the Gambian middle or upper class. The majority of these participants, however, indicated that they experienced a significant change in class status upon arrival in North America. Working low-wage jobs in the service sector contrasted greatly with the white-collar jobs many had held in The Gambia, as Abulie noted:

One of my first jobs when I got to Canada was.... to make the bills, my school would only allow me to work for 20 hours. So, a friend said, hey, it's easy to get a security job. I said, what me? Security? I have to stay up all night? He said, no it's not that hard you know, it's better. And I said... is it possible to do something else. He said, my friend, you just gotta start somewhere. It was hard for me, coming from the position where at the time I worked as a program manager with [a Gambian NGO], you know, going back to where I'm a security guard opening doors. That was super hard for me.

Sarjo and Saikou, living as a married couple in Canada, both came from an upper-class background in The Gambia - a background which afforded them the opportunity to move to Canada and work. While Saikou used to work as an accountant in The Gambia and Sarjo was a marketing specialist for a small business, they have both taken work doing quality control in factories. I have known Sarjo for several years, since before she moved to Canada to reunite with her husband. She used to speak longingly of moving to Canada, the work she would do there, and the money she would make for her family. When I visited her in Canada, her optimism had shifted to an acceptance of the difficulty of accomplishing her goals: "I didn't know what hard work was until I came here. [In The Gambia], you maybe work a few hours, sit at home, talk with friends. Here it is just work, work, sleep, take the kids to school then work some more". While, as Sarjo notes, she is still happy to be in Canada, working towards a future with her 
husband, she and her husband did not expect that the kinds of work available to them would be so drastically different from The Gambia, as her husband explained:

Saikou: You know, [in The Gambia] I used to work at a bank - an accountant. It was easy work, you have this air conditioning, you can wear a suit to work. Just that the salary is not so good.

Martin: Yea, and so how have things changed now?

Saikou: Well, alhamdulillah, you know, we are here, we are making money. But the work is difficult. You know, my first job is security - so I go to the building in the evening, sit there for some time. It's really boring. Then when I get off, I go straight to the factory for the second job. That one... you know, standing by this factory belt - everyday it's the same. You check the flour as it comes down. If you see something, you remove it. It really hurts your eyes after you do it all night, six days a week.

Many other participants shared Saikou's experience of moving from a white-collar workplace in The Gambia to a "low-skill", waged labor job in North America. While their higher-class status enabled them to migrate in the first place, it did not prevent them from either temporarily or permanently, falling in status upon arrival to the U.S. Other scholars have widely documented this phenomenon in migrant communities (Bray 1984; Castles, Haas, and Miller 2013), and in some cases, the difficulties of adapting to a lower class status leads participants to return home before they had planned to (Bolognani 2014). Of particular interest in this case study, however, is the intersection of class status and legal status among migrants. Other scholars have begun to touch on legal status as an important identity in migrant communities (Flippen 2014), but have yet to document the drastic change in outcomes this intersection can produce.

While the majority of participants I spoke with maintained their legal status throughout their stay in North America, some were unable to renew their visas after their first months in the U.S. or had family members who became 'illegal' at some point during their stay. These 'illegalized' individuals subsequently became unable to pursue success to the same degree that their 'legal' counterparts could. Samba and his wife, Amelie, arrived to the U.S. in the 1990s when, as Amelie explained: "things were different in the U.S. at this time. As long as you worked and didn't commit any crimes, you could stay for as long as you wanted, and no one would bother you". Initially coming on tourist visas, they subsequently overstayed them to continue working. Amelie was able to secure off-the-books waitress and care jobs, while her husband Samba began working supermarket jobs as a bagger and a cashier. Samba related to me 
that having been a banker in The Gambia, he felt he had "fallen from my former class, just working as a cashier". Of note here, in particular, is that while Amelie, as a result of working these kinds of jobs, "fell in love with food and hospitality", Samba related that he subsequently became depressed and unhappy with the kind of work he could obtain as an undocumented person in the U.S. While both had most definitely fallen in class status, Samba had also begun performing labor normally done by women in The Gambia, where men typically take "jobs that require power" such as manual labor, construction, and women take service sector jobs such as cashiers, waitresses, cleaners or cooks. Samba's change in not only class status, but his shift to 'feminine' labor perhaps resulted in the increased difficulties and stresses he encountered. This coincides with Sebastian Prothmann's (2018) work, where he found that many young men from Dakar, Senegal must also take up 'feminine' and 'lower class' jobs when they migrate to Europe.

After many years of working below-the-counter jobs, Amelie and Samba were forced to return to The Gambia once Immigration and Customs Enforcement (ICE) discovered their legal status had expired while doing an audit of an off-the-books money transfer service they had started - which will be explored in further detail in chapter 5 . While they encountered many difficulties living in North America as undocumented people, they were still able to return to The Gambia with some savings intact to start their own small businesses in the capital area. They still managed to 'make it', just not as easily as their documented counterparts, illustrating the importance of examining legal status. Amelie and Samba were not the only people I spoke to who encountered difficulties because of their lack of legal status in the U.S., but the 'white-collar' nature of the crime they were charged with allowed them more leniency than other Gambians who were deported from the U.S. Exploring how notions of 'race' play into Gambian migrants' experiences first requires a discussion of North American racial formations.

\section{3b I had zero idea of what racism was about}

When examining the experiences of African immigrants to North America, it is not enough to speak simply of 'race' or 'blackness' as a category of identity simply because of the fluidity of notions of race across socio-space-times. Abdi Kusow (2006) explains that simply using the language of race within migration studies is not sufficient due to the "conceptual gap between how blackness is defined in the United States and in other parts of the world" (p. 535). There is a need here, to distinguish between the concept of blackness as a race in North America and the 
myriad of other kinds of racial and ethnic identity that African immigrants carry with them. Kusow further elaborates that "African-born black immigrants embody a radically different classification system and identity categories to those available in North America. That is, while blackness is a meaningful identification category for American society, it does not necessarily carry a similar meaning for contemporary African immigrants” (p. 536). It is not enough, however, to point out that concepts of race and identity differ between The Gambia and North America. As described in my interviews, part of the experience of migration is navigating new identify landscapes - migrants must quickly learn to adapt to new forms of identity when they arrive if they are to survive, much less 'make it'. I draw here on Winant and Omi's (2007) term of "racial formation", which refers to "the process by which social, economic and political forces determine the content and importance of racial categories" (p. 16), to illustrate how participants navigated the unfamiliar terrain of identity in North America.

The new racial formations that participants encountered intersected with class and legal status to impact how they were perceived by people in North America, and how they could move through space in the course of their daily lives. While participants comprised any number of different identities related to being 'Gambian', a member of a particular tribe (Wolof, Fula, Mandinka), from a particular region (Badibunka, Foninka), or "African", all were forced, to some extent, to "become black". Asante, Sekimoto, and Brown (2016) describe 'becoming black' as a process wherein people from Africa "have to negotiate their Black identities in the United States to make sense of their shifting subject position as Black from their country of origin to the United States" (p. 368). For participants, this negotiation translated into a new set of skills surrounding social and spatial awareness. Exploring the mutual constitution of gender, race and space, Rashad Shabazz (2015) argues that in the U.S., black peoples' bodies are coded to belong in particular time-spaces and not in others, and that these 'codings' are highly dependent on not only race, but class and gender.

Some participants experienced these time-space codings acutely upon arrival in North America, through discrimination directed toward them as 'black' people. Abulie noted that he encountered discrimination on multiple occasions after entering Canada. While working as a security guard in a residential building, Abulie became aware that an older white woman disliked him and often complained about him to the management. One day, while he was working the night shift the woman called the police on him. Abulie described this encounter: 
She said I had sexually assaulted her. The police came... but fortunately for me, the [officer] was super smart. She just asked the woman what time was it? Around what time. She asked several details and came back with me to the place where the camera was, and she could see at any time of the night where I was in the building. Cause any floor in the building has a camera. So [the officer] just told the woman that you lied. She asked if I wanted to press charges against the woman. I had no idea what pressing charges was. I only wanted to be left alone. I said, no, no, no. I could not attribute that to anything but being racially motivated.

Abulie later recounted an additional encounter while walking with another African migrant near his apartment building:

There was a [white] couple who... they parked their vehicle and saw us, two of us, they looked at us, and you could see for some reason they were terrified. They thought we were coming at them. They looked at us and locked the door. Then they started running and running. [My friend] and I were just laughing. And we wondered why are they running? And then they explained, our one friend, later that 'the only reason they did that is because you people are black.'

Abulie summarized his time in Canada during our interview by noting that while The Gambia does have its own forms of discrimination and segregation, living in Canada "really exposed me to understanding what racism was. I'll be honest, I had zero idea, zero idea of what racism was about.... It never meant a thing to me until I was in the West".

While some participants felt folded into a category of 'blackness' that they shared with other black migrants and black Americans, others felt discriminated against not on the basis of being black, but specifically as African. Bakary indicated that upon beginning high-school in the U.S., he was bullied relentlessly for his accent and particular style of English. Amelie, working as a waitress, noted that occasionally, customers would refuse to tip her because of her appearance and accent. Zainaba, a young Gambian woman, encountered stereotypes about poorperforming African students while working on her masters' degree in the U.S.:

Zainaba: [We] would get asked very silly questions sometimes. Because people didn't understand the level at which... the achievements you made. I might be quite wrong. I'm not sure whether it's the African stereotype, or.... but I guess there should have been much more research done as to the quality of people coming over. For me I could understand, because maybe they couldn't gauge who they were actually about to meet. But for other fellows like myself, who had bachelor's degrees and have had some public experience and have also traveled outside of the U.S. and were at least exposed to some of these things. So it was a bit of a... I don't know.

Martin: Too simple? 
Zainaba: Yea.

While many migrants experienced discrimination from white people in North America, others indicated that the harshest discrimination they encountered was from black Americans. Suleiman , in reflecting on his time as a fabric trader and businessman in New York City, explained:

In America, the only hate I got was from black Americans... They want to hear me criticizing the white system, the European system, the American system. They expected that from me. And they don't see me dressing their way, which I don't. They like me to tell them about the things that I don't like to do... I remember I was in New York City one day, I was coming from the building to my car. A black man stood in front of me and said "you are a white man in black man's skin". Because I'm always in necktie. "You are a white man in black man's skin".

Suleiman' story, in part, illustrates the tense relations that can exist between immigrant communities of color and racialized groups who have been historically marginalized within the United States. Historically marginalized groups, as Laura Pulido (2007) writes, may express antiimmigrant sentiment and politics which is often entangled in a complication process of seeking to "belong to a nation" (p. 5). Immigrant communities and historically marginalized groups, as David Harvey (2007) writes, have also historically been pitted against each other by the capitalist class, stoking competition between different racial categories to depress wages and preclude alliances that could form amongst the working class - a social formation that Gambian migrants become a part of while working in the U.S.

The incident with Yunis further illustrates the insidious workings of white supremacy. As Angela Steusse (2016) indicates, "the role of whiteness in governing relations of power is ubiquitous, yet it is rarely recognized as an organizing principle because its workings are unconscious and unnamed" (p. 95). While these aggressions may appear on the surface to be only about jobs or dismissed by employers as simple 'infighting', they have much to do with competition incited by capitalism and white supremacy. George Lipsitz (cited in Steusse 2016) notes that

"the power of whiteness depend[s] not only on white hegemony over separate racialized groups, but also on manipulating racial outsiders to fight against one another, to compete with each other for white approval, and to seek the rewards and privileges for themselves and at the expense of other racialized populations" (p. 96). 
While Steusse, in her case study of Hispanic poultry workers in the U.S. south, noticed explicit manipulation of both Hispanic and black workers by the white supervisors to compete with each other for approval and resources, such manipulations are not always so obvious. More commonly, the "racialized system incentivizes people of diverse backgrounds to invest in the workings of white supremacy in hopes of reaping its benefits at the expense of those identified as Black" (Steusse 2016, p. 96). Other scholars have identified the way these incentives discipline migrant communities into "passing as white", in the case of Chinese immigrants (Calavita 2000), "acting white" in the case of Somali refugee communities (Lee et al. 2014) or "mimicry" in the case of colonial migrants mimicking certain aspects of colonizer culture in order to gain inclusion and avoid the discipline associated with being 'othered' (Lahiri 2003).

Suleiman personally experienced these incentives and reaped their rewards during his time in the U.S., where after years of wearing his suit-and-tie, receiving a bachelors' degree, and expanding his fabric-trading business, he opened a factory to export used clothing to West Africa. In his factory, he employed a number of black Americans, with whom he had tense relationships:

[T] hey expect me to talk to them like they are victims and all of this, which I don't. And then I see that they don't like the way that we communicate. Because I don't communicate in that way. And our way of life is completely different. And my other friends who are Americans, wealthy, well educated, they like me.

Suleiman ' story illustrates the ways that identities can intersect not only to produce difficulties, but also to produce great success. His legal status and attained class status, intersected with the way he disciplined himself within the North American racial formation to allow him greater success, and to 'make it' to a greater extent than other participants. Suleiman, however, was not the only person I spoke with who recognized that he could get ahead by acting in a certain way while in the U.S.. Others used the language of "conforming" to describe how Gambian migrants should behave to avoid being coded as 'black'. Several participants discussed this without explicit mention of race. Binta, a Gambian woman who hopes to send her daughters for an education in the U.S., used this language in the context of advice her cousin gave her on how to best prepare her daughters to move to the U.S.:

$[\mathrm{H}] \mathrm{e}$ tells you what America really wants, what kinds of people they want in their country, and if you go, how you should behave, to conform to society in America... If you want to be playful, drinking and all that you can also... it's easy to go that route. But 
he's trying to put the youths into a proper path where they can get into America, learn and benefit themselves.

Saidy, a young Gambian man who grew up in the U.S. before returning to attend the University of The Gambia, noted that his parents were unable to get jobs in the U.S. upon arrival because "they dress like gangsters, their body, they were like bad men... because their fathers were not there, so they make themselves like American people, like bad men... But when they get old, they started to find jobs. They stopped dressing like gangsters". Omar, too, indicated that Gambians needed to "behave properly" while living in North America in order to be successful. While no explicit mention of race occurs here, their comments imply that the way migrants dress, act and perform identity impacts their ability to 'make it'. In this sense, disciplining and policing themselves and their appearance in a manner pleasing to white people in North America would result in successes like employment, while acting in a manner that is unpleasing to white Americans, a manner that participants associated with black Americans, would prevent them from 'making it'.

While some participants navigated the racial formation to their benefit while living in North America, others experienced powerful disciplinary actions for not "behaving properly", as did Yeero. While working at a poultry-processing plant, Yeero noted that "I started buying drugs in [the city], bringing them to the [suburbs]. After work, I would go inside the town and sell, you know. That's where my troubles began...". Yeero was subsequently arrested and held in prison for nearly ten years:

Martin: Did you, at any point in prison, feel that you received different treatment because you're not American?

Yeero: Yes, it happens to me, not once, not twice. Sometime when I was in isolation, when they lock me up in a 1-bed cell for six months, sometimes one year. 90 days. Sometimes the officer would bring my food to the gate, look at me, spit in my food. I still received it, I just take my hand, scoop that spit out and eat it. In his face. It happened a couple of times.

When I met Yeero, he was working as a security guard at a telecommunication building in The Gambia. He told me it was the only job he could get because of a spinal injury he suffered while in prison:

The police, I was on the top bunk, the police pull me down, I came head first, injured my 
back. I'm still going through that, I'm having degenerative disease... disc. Still going through that right now.... Still going through the same sickness. Sometimes I'm in so much pain, I can't even sit. But when I sit, I have to sit a certain way. It happens, yes.

While other participants were disciplined for being "black" in white spaces, Yeero was most viscerally punished in the form of carceral power - power that still impacts his body over a decade later. In the process of navigating these unfamiliar racial formations, participants developed a new socio-spatial awareness of their bodies in relation to the structure of white supremacy. Disciplining and policing themselves to 'conform' and 'behave properly' emerged as key strategies through which migrants could approach their goals of becoming successful, and 'making it'.

\section{4 'Stay below the radar'}

While these kinds of self-discipline may have helped many participants to get ahead, there was a limit as to how they would go to do this while living in North America. 'Conforming' did not change participants' skin color from black to white, nor were those who identified as Muslims willing to hide this part of their identity to better integrate into North America. Because of this, many participants still felt 'othered' in public spaces, and that they needed to be careful to 'stay below the radar'. Rachel Silvey (2007), speaking on the case of the U.S., indicates that skin color and even certain garments may make migrants particularly visible, and thus 'othered' in public spaces. Jonker and Amiraux (2006) term the need to negotiate one's perception by the public the "politics of visibility". Often, migrants may benefit from remaining relatively 'invisible', in that by keeping a low profile, assimilating, or blending, migrant communities may avoid having negative representations generated about them. In the case of Gambians living in North America, the politics of invisibility may be a more apt framework for examining how representations are produced of Gambians.

The desire for Gambians in North America to remain 'invisible' is perhaps best encapsulated through an exchange I had during the preliminary phases of fieldwork. In trying to decide how best to approach Gambians living in the U.S., I went to a number of Gambian restaurants to speak with the workers and owners about my project. Most told me it was important research but indicated that it would be difficult to find people willing to participate. One in particular noted that: 
Yes, it is an interesting topic, but I don't know how you will find people who want to talk. Especially these days, Gambians try to stay below the radar. We just want to work and enjoy ourselves, not to be in the newspaper or anything. If I'm told you go out and start walking around the neighborhood here, asking for people to interview, they will think you work for ICE or something.

While this was an important moment for me in determining my approach to the project, it also illustrated the powerful disciplinary forces for migrants who become "visible" in the public discourse. This exchange came a little over a year after Gambian migrants' first real venture into the public eye in the United States. In early 2018, a handful of Gambians who were living in the U.S. on Temporary Protected Status were deported to The Gambia under an agreement between the Trump administration and the Gambian government (Siegler 2018). This brief foray into the headlines, along with the knowledge that people who had been living peacefully in the U.S. for years could one day be separated from their families and sent back to The Gambia made 2019 an especially sensitive time for Gambians living in the U.S. and hoping to remain invisible in the "public eye".

While it was especially important for Gambians living in the U.S. to remain 'below the radar', even migrants living in Canada felt pressure to maintain low levels of visibility, particularly surrounding their Muslim traditions. Sarjo illustrated this in the context of the Tobaski, or Eid al-Adha holy day, when animal sacrifices are traditionally made. Gambians typically kill a goat, ram or bull for this holiday. This is the time of year when Gambians living in North America indicated that they missed home the most, so many tried to replicate the Tobaski festivities in their new communities. Sarjo explained that:

So, you know there are so many Gambians in this area, and we all really miss this Tobaski, so we wanted to kill one of these cattle and share the meat. But you know, for us, we cannot just go outside the apartment and kill it, people would look at you so strange. So, we had to go far out into the country where there is one Gambian man with some land. There we had the Tobaski with a big cow!

While there are indeed practical implications to Sarjo's family's decision not to celebrate Tobaski in a densely populated area (even I would not consider slaughtering a cow outside my apartment), the decision also illustrates the learned necessity to maintain a low profile and to not perform activities that situate them as 'other' in their new communities and interfere with their goals of living peacefully, earning money and 'making it'. 
But there was a limit to how far migrants would go to keep a low profile. Sarjo later explained that although she sometimes receives negative attention for wearing a headscarf in public, she would never consider not wearing one. While this does demonstrate participants' unwillingness to compromise on certain areas of identity, it also suggests that female, Muslim migrants may experience more discrimination for wearing the headscarf as a visible identifier of Islam, as opposed to Gambian men, who rarely wear such identifiers in North America.

In the face of so much pressure to conform and 'stay below the radar', participants also actively engaged in place-making practices in the communities they now call home. Part of this involves selectively making themselves visible in certain ways. Gambian migrants often engaged in kinds of community building that made them more visible, but also reproduced certain kinds of social relationships from The Gambia to provide mutual aid to one another, and to maintain attachment to Gambian culture. In the U.S., among more well-established migrant communities, Gambian diaspora associations have emerged that provide communal spaces to celebrate holidays, naming-ceremonies, and Gambian Independence Day. These groups have also become actively involved in not only their local politics, but also in Gambian politics. West African restaurants often constitute less-formal spaces where Gambians can go to spend time with each other and other West African nationals and engage in a kind of place-building. In newer immigrant destinations, such as Canada, these kinds of spaces may not yet be available, but as migrant communities grow, individual families may gather once or twice a week at someone's apartment to eat from a communal bowl, listen to Gambian music, and converse in Mandinka, Pulaar or Wolof. These communities form the spaces that migrants can fall back upon to replenish themselves when their everyday realities involve distancing themselves from their Gambian identity.

While attempting to remain "invisible" to the public eye in North America has many benefits for Gambian migrants in terms of allowing them to pursue their goals of 'making it' without being disciplined as 'other', participants had limits to how far they were willing to conform towards these goals. 'Staying below the radar', while a strategy for getting ahead in North America, was only pursued by participants to the extent that it did not entirely separate them from Gambian and Muslim identities. 


\subsection{Conclusion}

As this chapter has highlighted, Gambian migrants often conceive of international mobility as a means to 'make it', or as an indicator that they have 'made it'. While many relied on the stories of other migrants, or geographic representations of North America through which to construct images and plans towards 'making it', they often found North America very different from what they had imagined and encountered many difficulties resulting from the way their bodies were coded along the lines of race, legal status, class and 'other'. Migrants' desires to pursue their dreams of success in North America led to a number of strategies to reduce the negative aspects of life there, including 'hard work', 'conforming' and 'behaving properly' within the racial formation, and 'staying below the radar'. But, as participants indicated, there were limits to how far they would change themselves to pursue their dreams of success, and migrants also developed spaces in which to exercise agency and reproduce themselves as uniquely 'Gambian'.

While Gambians living in North America have indeed encountered difficulties and discrimination, the small numbers of Gambians living there and their relative "invisibility" has largely protected this community from the kinds of negative political discourse about migrants that other groups, such as Central American and larger Muslim migrant communities experience. When Gambians in North America feel politicized, it is not as a result of being Gambian, but of being swept up into larger societal discourses about migrants - especially from Muslim states. The resulting lack of discourse from either North American or Gambian governments about this specific transnational community has left migrants themselves largely responsible for representing their own experiences, both in North America and in The Gambia. In the following chapter, I will explore how the lived experiences of Gambians living in North America become represented transnationally - and how these representations contribute to perceptions of migrants in The Gambia, further migration flows, and notions of 'development' or community improvement at home. 


\section{Chapter 5. Transnational translations}

My uncle lives in the U.S., but he don't come back here for some years. He built a house down [near the family compound]. It's a huge house, and he painted it green. No one else has a house like that. People call it 'Green House', they even gave it a name! And people are always going to look at it - sometimes they take a walk over there just to take a picture of his house.

Interview with Saidy

As I have established, Gambian migrants often go abroad in the hopes of 'making it' for themselves and their families. While migrants' stories thus far have illustrated what 'making it' looks like while living abroad, especially with regards to the sacrifices they must make, and the way that identities change and morph in the process of 'making it', this chapter focuses on how 'making it' impacts the families of migrants, and how it becomes represented in The Gambia. As I will explore, 'making it' is a contradictory term in that the difficulties that migrants encounter on the way to 'making it' are not necessarily reflected or represented in The Gambia. While migrants go to great lengths themselves to demonstrate their own success to their families and communities at home, migrants' families may also fail to understand, or actively obscure the difficulties their family member encounters in the process of 'making it'.

Key to this chapter is the process of translating lived experiences into representations across different states. Despite the ever-increasing availability of communications technology and travel, migrants are often still separated from their families by great distance, time zones and borders. Here, the GNA community must be recognized as a transnational one that cannot be contained or conceived of as existing in one place - it spans the U.S., Canada and The Gambia. In this chapter, I begin to link the mobilities paradigm with a transnational framework to illustrate how experiences and representations of mobility transmit and translate through transnational networks.

Transnationalism understands migration not simply as an individual act, but as part of a community that spans borders and states. Some mobilities scholars have begun to engage with transnationalism as a means to understand representations of migration (Salazar 2011; Anthias 2012), but these two areas of literature remain largely unlinked. Using the language of 'making 
it', I explore how lived experiences are communicated across and represented within transnational communities, how notions of success are constructed, and in turn how migrants themselves may challenge or change how their experiences become represented.

\section{1 'Making it' materially}

Just as "making it" can to refer to the visions of success migrants construct around imaginaries of North America, 'making it' can also help to explain how migration is represented in the GNA transnational community. Here, 'making it' manifests in both material and ideological ways. Bakary noted that many migrants are strongly motivated by the potential to send money home to improve the material existence of their families: "[Migrants] are out there, they're making it, they're sending money home for their family to build nice houses, and you know... others are just here in The Gambia and they don't have it. It's difficult on them". In this case, visions of the accumulation of material wealth represent the success associated with migrating to North America or Europe. These can form powerful geographic imaginaries, not just of what life abroad is like, but what life could be like for the families of would-be migrants if they 'make it' and start sending money home. Remittances, in both the form of money through official channels, and other forms such as goods in kind or 'social remittances', form an important representation of migration in The Gambia.

\section{1a You cannot compare those two families}

Migration studies, classically, has paid much attention to remittances as a material benefit for families of migrants living at 'home'. The New Economics of Labor Migration (NELM) theorists argued that remittance economies stood to change the fortunes of "developing states" as certain areas of the world come to "specialize in migration", or exporting labor (Taylor 1999, p. 64). NELM often construed remittances with 'development', or material changes to the lives of migrants' families, noting that this development was often unevenly spread (Massey, Goldring, and Durand 1994). While The Gambia has not developed itself as a 'labor exporting' state in the same manner that the Philippines, or Central American states have, there still exists a culture of sending one's children abroad, once they come of age, to work and send home money to improve the lives of their parents and extended families. Other scholars have documented these 
relationships in detail in West Africa including Sebastian Prothmann (2018) with regards to young men from Dakar, Senegal seeking to travel abroad and earn money to begin supporting their parents; Lama Kabbanji (2013), who illustrated the material impacts of remittances on 'development' in Senegal; and Madeleine Wong (2006) has shown the gendered nature of remittance receival and usage in Ghana. The Gambia's own Omar C. Kebbeh has devoted much of his career as well to analyzing the economic benefits of Gambia's diaspora on 'development' at home $(2013,2014)$.

Remittances currently form an enormous basis of the Gambian economy - estimates put this at $22 \%$ of Gambian GDP (Kebbeh, cited in Courtright 2018). A growing number of families in The Gambia are supported in one way or another by remittances from abroad. Many families in the capital and surrounding urban areas have at least one relative abroad who sends them money regularly, and often, families in the rural areas have a relative living in the capital who receives remittances and then sends it back to the village. The receipt of this monetary support is often highly visible. As Saraldu explained:

You cannot compare somebody whose relatives are in the United States and someone who does not have [that support]. You cannot compare those two families. The one in the United States will be able to support his family back better than the guy who is in his family here... I have seen, because even in my own village. If you see any good house, undoubtedly, their people [are] in the diaspora, they are not within the Gambia. Those within the diaspora, they build very solid houses for their people back home, they are living good. Definitely improve their life, their living conditions.

Saidy noted that often the first thing families did upon receiving money from abroad was to improve their living conditions. Saidy's father sends back regular remittances from the U.S. When the family receives the money, they often purchase meat, sugar and eggs, all luxury items in rural areas. His father generally sends them smartphones as well. Saidy also, in the quote at the beginning of this chapter, illustrated how his uncle's compound has become a neighborhood landmark - a symbol of his success abroad. Omar, whose father also lives in the U.S., noted that their family also has a large compound paid for through remittances.

Compounds, in The Gambia, serve as highly visual symbols of a family's status, and throughout the small country, there is a discrepancy between compounds who have somebody living abroad and compounds that do not. Kebbah explained that "when you go to the provinces, you can always tell who has someone outside. The ones with the big gate, the satellite TV dishes, the electricity and taps. Those all have someone sending it back to them". Concrete buildings 
over ones of mud brick, corrugate steel roofing over thatch, painted walls over whitewashed, and automobiles over donkey-drawn carts. All of these represent, in The Gambia, the migration of a family member to the 'outside', and the 'support' provided to family members. Migration becomes, through the flow of remittances, represented in the visual display of wealth by family members. Just as the act of migration is 'laden with meaning', so too is the way that migration is represented in the transnational community. Others have explored how exactly remittances as representation are given meaning in transnational communities. Harper and Zubida (2016) indicate, in the case of laborers working in Israel, that remittances may serve as a form of social mobility. They argue that remittances and their families' resulting visual displays of wealth helps the migrant laborer to feel more 'visible' in their home society despite their absence. Mckenzie and Menjívar (2011) also show how the visibility of remittances may play into gendered notions of affection and 'breadwinning'. In their case study of Honduran women whose husbands migrated to the U.S. for work, remittances "convey assurances that the men have not forgotten them, and they become expressions of love" (p. 63). Visual displays of wealth in The Gambia are one such way that Gambian families show that they and their loved ones have 'made it'.

\section{$5.1 b$ They have much more respect after}

While transactional, cash remittances form an important means to support and show affection for family from abroad, researchers have identified many less-tangible benefits that come along with the cash. Peggy Levitt first described these as "social remittances", or the "the ideas, behaviors, identities, and social capital that flow from receiving- to sending-country communities(1998, p. 924). Others have expanded on this notion to include cross-cultural exchange and increased civic participation (Isaakyan and Triandafyllidou 2017), and transnational political engagements (Boccagni, Lafleur, and Levitt 2016; Lacroix, Levitt, and Vari-Lavoisier 2016). But as participants indicated, the most important non-material aspect of remittances in The Gambia was the increased stability and respect associated with having a family-member living abroad. Bakary, whose parents moved abroad first before he did, explained the benefits to his family in The Gambia:

But well I will say you know, alhamdulillah. My mom and dad made it to the U.S., because at least they can provide for my family here in the Gambia. It's like we kind of move up a little bit. Even though we were like kind of poor, but then we kind of move to 
a middle-class kind of thing. Because whatever occasion happens, you know my family in the US will just support them.

While families certainly enjoyed the material benefits of money and goods in kind sent by family members abroad, the ability to rely on a migrant living abroad for income allowed Bakary's family to stop living paycheck-to-paycheck and enter a higher-class status that they could have without that support. As Bakary further explained, the simple presence of a family-member abroad did much to increase a family's respect and social clout:

Martin: Does migrating somewhere to the US or Europe... does that change a person's status here after they do that, and the status of their family?

Bakary: Yes, they have much more respect after. You get much more respect then. Because they feel like you have it all... The way people see it is like OK, this person is like in the US or abroad, they get better pay, there's much more opportunity. So they see like, ok. That person would make it. He or she would make it in life. So, they respect you for that, and depend on you.

Cheikh Anta Babou (2008), found similar patterns of status change in his case-study of Senegalese female hair-braiders living in the U.S. where the foreign money they were able to mobilize for their families began to replace what he terms more traditional "non-material sources of prestige and authority", such as family name and caste status (3). Participants I spoke with, however, noted that the money they or their families earned in North America did not necessarily replace traditional forms of status, but augmented them and allowed families in The Gambia to perform acts of charity and ceremonies that only higher-status families would have been able to do. For many, this took the form of expressions of Muslim charity. For example, Saidy noted that his father was able to perform many acts of charity using the money he earned in the U.S., including giving gifts during Ramadan, building a solar-pump well in his village, and even converting someone to Islam due to his increased status. Binta, whose husband and brother earned money abroad, was able to send her father to Mecca on the hajj, an expensive journey that the family would not have been able to undertake without access to foreign money.

Increases in class status, demonstrations of wealth and acts of charity inform representations of migration - representations that flow, along with remittances, from migrants to their families, and then filter from families into the broader community. These representations 
may then reinforce imaginaries of the rewards that one could reap by traveling abroad to earn foreign money before returning home. Regina Römhild (2016) argues, that these kinds of relationships result in the remittance of 'geographic imaginaries' about life elsewhere. In her case, migrants living in Europe sent home "imaginaries" about what life in Europe is like. Those living in The Gambia often showed me pictures from their relatives living abroad: pictures taken in shopping malls; next to high-rise apartment buildings; in expensive boutiques. Participants in The Gambia indicated that their relatives was having the time of their life, living in luxury, enjoying themselves and their money: they had 'made it'. Because the remittances and social capital associated with migration go so far in The Gambia, migration becomes represented as an act that leads to quick success once someone arrives in North America. Migrants, too, despite having their own geographic imaginaries shattered upon arrival in North America, often reinforced these imaginaries when interacting with family, or when visiting home.

\subsection{Representing the 'signs and styles' of success}

While many representations of success in North America often occur while a migrant is not physically present in The Gambia, return trips allow migrants to personally represent their experiences abroad to their family, friends and community. On the rise in The Gambia is a form of visiting that participants referred to as "semestering", in which a migrant who lives abroad the majority of the year returns to The Gambia during the Christmas holidays to visit. The term "semester" is both a verb, referring to the act of returning for a short period, and a noun, referring to the time of year and the person who returns to visit. Each year, from mid-November to February, the semester occurs in the Gambian capital area, where many migrants from all over the world come home to see their families, communities and each other. The Gambia is not unique in having these periods of the year when migrants or members of a diaspora community come to visit. Other scholars have termed these encounters "diaspora tourism" (Scheyvens 2007; Mahieu 2019). These brief visits form encounters where representations of life abroad can be traded for nostalgic imaginings about life at 'home'.

For the semesters, these encounters present an opportunity to demonstrate their success abroad. Many semesters, upon returning home perform a kind of success that belies their experiences living abroad. Noel Salazar (2011) indicates that in doing so, the semesters shape peoples' imaginaries about mobility. He writes that in an increasingly global world, people 
are beginning to imagine the possible lives that might be available 'out there' because they are often convinced that life is 'better' elsewhere. Being exposed to media, goods and ideologies never before available, people are dreaming the signs and styles of a global order, while facing ever-narrower means by which to satisfy them (p. 578).

These "signs and styles of a global order" play important roles in shaping desires and plans, and the semesters' yearly visits to The Gambia may provide the fodder through which these signs and styles are constructed. Researchers have examined how exactly these signs and styles manifest in West Africa, more broadly. Langevang (2008) indicates that the notion of 'respectable' livelihoods is the primary driver of decision-making among youths in Accra, but that the pathways towards respectability is increasingly non-existent, or at least, unavailable to them while in Ghana. Prothmann (2018) demonstrates similar desires for respectability in the case of young Senegalese men in Dakar, the ability to enter adulthood and manhood - and provide for themselves and their families. The desire to be seen as successful, respectable, or as an adult, reflects part of the imaginaries of migration. In many cases, migrants coming to visit as semesters seek to portray images of success and respectability. These are also reflected and represented in the act of providing for a family, especially in sending remittances.

As Bakary noted, when he came to visit The Gambia as a semester, he would rent an apartment in the tourist quarter and "spend money like no other", taking his old friends out to tourist clubs and restaurants that they would never have been able to afford. Jessica explained that "around the second week of November, all of the Kombo girls will break up with their boyfriends so that they can date the semesters when they come back". The opportunity to date a semester, or spend time with one, not only allowed Gambians access to experiences normally only available to tourists, but to a change in status, at least over the winter months. These visits made lasting impressions on young Gambians in the capital area, as Bakary explained that "they see the things that we're doing when we come for holidays. So, they're like: 'okay, we want to be like them. And the only way we can do that is by [migrating]'. The mingling of semesters in the capital area sets up a highly visual representation of migration as a means to success, class status change, and the chance to 'make it'.

While semesters put on a show for their families and friends, Jessica explained that migrants frequently over-extended their finances on their trips home in order to feel like they had 'made it', when in reality, many struggled financially abroad, and felt part of an underclass of people. Jessica noted that: 
Lots of Gambians put on a show when they come home to visit around Christmas. They are not really doing that well personally, but they buy [airline] tickets when they are on sale, they buy fancy designer clothing, expensive handbags, the nice shoes. Once they arrive in Gambia, they make everyone to believe they are doing well, that they are wealthy, but they keep the price tags on the bags and clothing. When they return to the U.S., they return all the clothing and bags, and get their money back.

While the kinds of "semestering" that participants spoke of is largely performed by young Gambians, both men and women who are often unmarried, older Gambians who come home to visit may still perform success and respect in other ways that do not involve European-style restaurants and dance clubs. Dembo's older brother, who lives in the U.S., comes home during the semester holidays each year, but instead of spending money at the tourist strip, he brings back lots of gifts from abroad to distribute to family members - phones, computers, new clothing and shoes, and food items that are unavailable in The Gambia. Such generous displays have cemented his status within the community as a person of respect, who has 'made it'. Ebou, who lives in the U.S. most of the year, also comes home during the semester holiday. But instead of sharing wealth in ways that reinforce 'western' visions of success, he normally brings items or funds to contribute to the upkeep and beautification of his community mosque. In 2014, he brought a loudspeaker back home to project the call to prayer. The following year, he had tiles shipped back with which to pave the floor of the mosque. In 2018, he funded the construction of a new building for the dahira, or Qur'anic school. In 2019, he told me he eventually plans to make the hajj to Mecca, which will further contribute to not only his own respect, but that of his community.

Migrants who come home to visit have many paths with which to demonstrate that they have 'made it' to their home communities. These visible displays of wealth serve to indicate success abroad, often utilizing the 'signs and styles of a global order'. But their displays often obscure the lived experiences of migration to a state of the global North, and the difficulties inherent in it. Many migrants, indeed, in their public-facing interactions, largely represented their own success and reproduced geographic imaginaries of North America as a place of wealth and ease of living, even when this representation did not match up with their own lived experiences. The desire to remain 'visible' in The Gambia while producing class-status changes for their family members, however, often leads 'successful' migrants to reproduce these images of life outside of The Gambia. Not all migrants, however, are able to return yearly to The Gambia to 
demonstrate that they have 'made it'. Even amongst Gambian migrants, there exists uneven access to the ability to represent one's experience of mobility. Tim Cresswell terms this unequal access to mobility and representations of mobility a "kinetic hierarchy" (Cresswell 2012), where a multiplicity of identities intersect to position someone at a point in this hierarchy. Gössling and Nilsson (2010) argue that in the case of the global North, certain social structures, such as frequent flyer miles, serve to produce an "upper class" of kinetic elites who have easier access to aero-mobility. Their increased mobility continuously produces them as elites and reinforces their higher social standing. In the case of Gambians, legal status and class privilege allow individuals the ability to travel back and forth between North America and The Gambia. These 'mobile elites' have greater ability to represent their experiences of movement in person to their communities. They can influence how migration is represented - and largely choose to depict themselves as successful to the community at large, significantly increasing their ability to influence how migration is represented. Others cannot travel to The Gambia at all or as frequently due to their lack of legal status or funds. They do not have as much agency in representing their own experiences in The Gambia. The 'semesters', with their ability to come home and portray themselves as successful, affluent and respectable, perhaps inhabit the upper tier of this kinetic elite in The Gambia.

\section{2a They take their money from hellfire}

Because the GNA transnational community remains relatively depoliticized in North America and The Gambia, they often have considerable influence over how their experiences of mobility are represented at home, particularly for those with greater wealth and legal status. Migrants often reproduce these imaginaries in large, public-facing ways that perform success. However, participants also indicated that migrants found opportunities to confide in immediate family members and close friends the difficulties they faced while living abroad. These more intimate encounters became spaces where migrants could nuance the narrative of 'making it' and bring imaginaries of life outside The Gambia into closer conversation with the fact that the means through which migrants can achieve success and the 'good life' are constantly shrinking.

Penda and Dowda's story illustrates how these how individuals may present different narratives of 'making it' in different spaces. Penda and Dowda were married in The Gambia several years ago, right before Dowda moved to Canada to begin working in construction. 
Dowda, in many ways, embodies the image of someone who has gone to North America and 'made it': he provides gifts to Penda's parents and pays the children's' school fees, he tries to come home during the semester to visit family and friends. In my interview with Penda, however, she presented a different narrative of her husband than that portrayed by her family, who widely believes life in Canada to be easy and carefree. Penda noted that before, Dowda had expected life to be easy in Canada as well, but:

when he went there, he even told me that these people they take their money from hellfire. So, I think everybody should know, if somebody is here, when the man sends you something, you have to be grateful for it, so it means that it's not easy for you to have money there... it's difficult to earn money and everything is taxable.

Where the public-facing representations alluded to wealth and the good life, migrants were more candid with family and friends in one-on-one interactions. Bakary too indicated that he had some idea that North America would be difficult and different than what he imagined it to be based off of conversations with his friends and family who had migrated while he was growing up in The Gambia.

Saidy shared with Ello the story of when he first realized the sacrifices his father made in order to move to the U.S. He grew up in The Gambia after his parents had left to go to the U.S. and felt that his life was pretty easy compared to his peers, since his parents sent money every month. His mother would come home to visit occasionally, and bring them gifts when she came, but his father never visited. He never understood why until, as he shared with Ello, he moved to the U.S. to join his parents and discovered why his father never came to visit:

Saidy: I find out it's not that easy. They had to work, work, work. My father, he used to wake up at 11 at night, up to 8 in the morning, he comes back from work... he used to work in a restaurant.

Ello: Did he ever visit home? In this country? He never came to visit?

Saidy: No, since he went to America, he never came back to Gambia. He don't have his papers (legal documents).

Ello: Do you think if your father have papers he will come back?

Saidy: Sometimes I think my dad like Gambia too much. The day he get [his papers], the next day he will go to Gambia. 
His father's lack of documentation not only prevented him from leaving the U.S. to visit The Gambia, but it also relegated him to off-the-books jobs which, as Saidy mentioned, he worked long hours to save up enough money to send home. Saidy's father's situation is not unique by any means. As other participants noted, and as I gathered over my time living in The Gambia, there are many Gambians living in North America who are unable to come back. The high social visibility and respectability of those migrants who do return to The Gambia from abroad and make displays out of their success and wealth make it more difficult for those migrants who are unable to return, even shaming them for their inability to appear successful and contribute visibly to their family's well-being. The politics of migrant visibility and the geographic imaginaries of the global North as a place of success assemble to construct a kind of stigma around migrants who do not or are unable to return to The Gambia. Participants whom I spoke with indicated that these people have "cut ties" with their family and The Gambia. Binta explained to me that:

Some does not come back. To me, that's from the irresponsible people. We all know that the toubab life and African life is different. If you are [in North America], you are just alone. Anything you have is for you. Maybe that's why they are staying there. But people who stay there, I don't think... to me I am not very supportive of that. I always talk about it. Because you can go and find... even if you don't get, you can come back. Back to your country. Why sitting there, just uselessly. Because you are there alone. There are some people who just don't want to share, they don't want to stay with people. Maybe those that don't come back... maybe all they have, they don't have enough, they think they cannot share it, and they decide to stay. Things like that. I don't think there is a strong reason for me to convince me of a person staying and not coming home, or you don't communicate. I don't know what is behind their mind. I think it is really a bad habit.

The construction of those who 'cut ties' as people who have lost touch with their African way of life can, in many cases, stigmatize undocumented Gambians living abroad as “toubabs', or foreigners, who in their pursuit of the good life, have forgotten where they came from. The difficulty to live in both worlds at the same time - as an immigrant to North America, and as a Gambian who has 'made it' and has the responsibility to demonstrate their success to those at home, often strains transnational relationships, as Sainaba noted:

[T] hey cut ties for different reasons. Because I've heard stories of people cutting ties because family members are asking too much, putting pressure on them. Each time they call, it's about money. Or sometimes they don't want people to know their location, just in case the papers are not in correct order. You know, and for different reasons, they can just cut ties, or probably because they are ashamed of all these years they have been in America now... they don't talk to people. 
Bakary noted too that his parents, despite their legal status, felt strained by the constant need to communicate and provide for family at home:

Well my family that lives [in The Gambia] depends most of the time on my family abroad. And it got to a point where my family in the U.S. would not even pick up their phone calls... they will bother you 24/7. They don't even think about the time difference. They will just call anytime of the night.

The need to remain visible to family members, either through visits in person or cash remittances has uneven impacts upon migrants, where the identities of class and legal status intersect to make those with fewer financial means and without documents most unable to visibly contribute to their family's success. Even those migrants of a lower-class who have legal status may, to some extent, be able to return home and contribute to their families and communities. But those without legal status may not only experience the difficulties of living in North America as an undocumented person but may also be disciplined by their families for having "lost touch" or being "unsuccessful". Perhaps no one experiences this more viscerally than those undocumented persons who are deported back to The Gambia and forced to reintegrate into society after potentially cutting ties with their family due to their lack of legal status and inability to send home remittances. Yeero, who I introduced in the previous chapter, was deported to The Gambia in 2007 after spending 10 years in and American prison. When he arrived in The Gambia, he had nothing: no money, no gifts, no work experience from abroad. Nothing except the physical and mental scars from years of drug use and a decade in prison. He described to me the hardships he encountered with his family, who expected him to come home wealthy and ready to begin supporting them:

Martin: How did that feel to finally come back?

Yeero: Painful. It was very painful. Very painful. It was very difficult. Especially with my family. It was very difficult.

Martin: Can you describe a little bit about what kinds of difficulties?

Yeero: When I came back, I find the house was, the family was dysfunctional... When I came, it was very tough. What they were expecting of me, they were thinking that I was coming with millions, and I came back, just out of prison. So, I'm still going through that still with my family...right now we are fighting for one property. But not too long ago, one of my sisters served me. She served me a paper saying I should vacate the compound. But I just laughed at that letter... It was very difficult man and still is. But you know, I thank God man, for the strength I've got to resist some stuff man. Thank God for that. I 
don't look back and regret what happened. I know that's what was ordained for me to happen, so I accept it in good faith. And I don't have no regrets. And I don't have no hard feelings towards nobody. Back there and here. Even my family, I don't have no bad feelings towards none of them. I just take the punches as they come.

Yeero's case was exceptional at the time: he was one of a small number of deportees from North America or Europe. But since 2007, deportations have become much more commonplace due to changing bordering practices in Europe and a new agreement between the U.S. and President Barrow's administration to begin accepting non-criminal deportees. This came to a head in 2018 when a number of Gambians who had been living for decades in the U.S. under suspended deportation orders were suddenly deported (Siegler 2018). Since a change of government in 2017, the Gambian Government has signed agreements with many states of the global North to begin accepting deportees, and the numbers of those sent home have increased, especially from EU states (Jeffang 2019). As Yeero explained though, returnees are crushed by the dual burdens of their traumatic experiences and the high expectations of family:

When I got deported, I didn't have no where to go and cry. No where to go and cry, you understand. For example, when I come back, if I had found that something was set up for deportees when they come back to their country, it would have been less painful for me, or other people that are deported. Because I know a lot of people who are deported, some of them went astray, they got mad, went to the streets... because of family. The family will disturb you, you travel, you come back with nothing. If you are not strong mentally, you go off the board. The family tried all kinds of ways, they came at me all kinds of ways, different kinds of ways man. But I just keep the faith. That's what was in it for me.

Since my conversation with Yeero, hundreds more Gambians have been deported, mostly from Europe, and found themselves in circumstances they never imagined when they left home. While 'successful' migrants may come back sporting the latest fashion, smartphones and tablets, those like Yeero return to find themselves stigmatized by their friends and families for not 'making it'. Those like Saidy's father may never be able to return home.

While deportees and undocumented Gambians living abroad often struggle in ways their counterparts at home cannot imagine, their experiences also create spaces for encounters that shift the narrative about success, 'making it', and migration. These encounters are painful, especially for the migrants. But they do work to bring the representations of migration, and indeed the imaginaries constructed about states of the global North into closer conversation with the lives of migrants who went abroad, struggled to 'make it', and were spit out by global 
economic and legal systems to come home with nothing. But of course, as exemplified by Yeero, no one ever comes home with nothing. Despite his horrible experiences in the United States, he came home with a kind of tenacity and resilience that allowed him the "strength to resist", to "take the punches as they come" and "keep the faith" amidst all of his challenges. Indeed, Yeero and many other migrants who either live abroad or who have returned to The Gambia have developed strategies, mindsets and skills that allow them to work within, around and through systems of oppression that immobilize, disenfranchise and dehumanize. They possess insight into both worlds: knowledge of The Gambia and North America; they are able to function within a global capitalist market while also understanding other ways of being and doing. Increasingly, the relationships produced by and the technologies utilized by transnational communities allow the GNA community to engage with their family at home and provide mutual aid in ways that present alternative narratives of 'making it'.

\subsection{Transnational cooperative economic activities}

Not all migrants who were able to 'make it' expressed their success in ways that reinforce the 'signs and styles' of a global order. Many began to organize ways to help their loved ones 'make it' in ways that bear closer resemblance to the solidarity economies of black communities in the U.S. (Gordon-Nembhard 2014; White 2018) than to the performative success of the semesters. Saikou and Sarjo, living in Canada are part of a small, but growing community of Gambian migrants, have begun to organize a small group that combines their resources to send back bulkgoods to their relatives in The Gambia:

We normally are able to fill one shipping container and send it back each year. There's plenty of different stuff that goes in: cars, these second-hand clothes, stuff you buy from Costco, American foods that we can't get over there, baby formula, phones, electronics, and computers. We can usually fit 3 cars in the container, in addition to a lot of other things. You know Gambians can buy that stuff over there, but we can get it to them for much cheaper this way.

Saikou noted that it only costs his group about $\$ 3,000$ CAD in shipping fees and tariffs to send a 40-foot container to The Gambia. Once the container arrives, his relatives transport it to their village, unload the cars and establish a storefront at the end of the container from which they can sell all of the goods inside. Not only does this provide a number of gifts to his immediate family, but it allows them a means of income, and reduced priced goods for others in the village. 
Such activities may have impacts well beyond transactional remittances. Studies which only look at remittance numbers from money transfer services would miss not only the value of the goods being sent to The Gambia, but also the money saved by the recipient family from not having to purchase the goods themselves, their income from the sale of the goods, and the money saved by those purchasing goods from the shipping container rather than from importers in the capital. All this without mention of the relationships that are maintained through such cooperative activities, the improvements to quality of life, and the increased opportunities as a result of the continuous income from the shipping containers. The activities of Saikou's group of friends and others like it throughout North America and Europe are reminiscent of the kinds of buying clubs that Gordon-Nembhard discusses, in that they provide goods to a community at reduced price and reduce the influence of non-community members. Many of the importers in the Kombo area are expatriates from Mauritania, India, Lebanon and China - they often place substantial upcharges on imported goods, pay their Gambian employees poor wages, and circulate profits within the expatriate community. Such transnational cooperative economic activities represent ways to circumvent state-dominated economic systems while supplying communities with goods that improve their lives.

Migrants in the GNA community have also found ways to improve the experience of sending and receiving transactional remittances. As I mentioned in Chapter 4, Samba and Amelie, while living in the U.S., started a small money transfer service to help U.S.-based Gambians and Senegalese send money home. Amelie indicated,

the problem at the time was that if you used the established transfer bureaus, there was no paper trail, no transparency, and it was difficult to ensure that your money had arrived. Gambians sending money home wanted a better system to ensure that their relatives got the remittances without losing too much in fees.

The fees charged by transfer services, such as Western Union, often take a substantial percentage of the money being sent home, and this fee is always borne by the sender: the migrant. While Amelie coordinated with migrants living in the U.S. who wanted to send money home, Amelie's mother, who had the ability to come and go from the U.S., began carrying cash back to The Gambia on her person. Upon arriving, she would distribute it to the recipients. Samba, with his background as a banker, handled the accounting aspects of the business. During their years in operation, they were able to help many Gambians and Senegalese living in the U.S. without documents to send money home and avoid large fees. Unfortunately, as Samba shared, after 
September $11^{\text {th }}, 2001$, ICE began to do routine audits of such small enterprises and began to investigate Samba and Amelie's business as a money laundering and terrorism funding operation. Still living as undocumented persons in the U.S., and given the option, they voluntarily deported back to The Gambia.

However, their service to The GNA community and The Gambia at large did not end there. Amelie, who had worked in the restaurant industry, mentioned that the U.S. "is where I fell in love with food and hospitality. I wanted to eventually open a restaurant in The Gambia with food affordable for Africans". As with the importing business, many of the restaurants in The Gambia are run by expatriates and charge prices that only other expatriates, tourists and wealthy Gambians can afford. With the emergence of a Gambian urban middle class, there is a need for restaurants that those earning a Gambian salary can afford to frequent. Upon their arrival back to The Gambia, Amelie and Samba opened a canteen to sell snacks to schoolchildren at reasonable prices. When I visited in 2019 , they had recently renovated the canteen into a fullservice restaurant that sells both Gambian and American food at affordable prices. This has created a number of full-time jobs for young people in the area as cooks and servers. While many of her employees have no work experience, she provides a lot of on-the-job training in order to "bring the American work ethic to The Gambia and mix that with [our tradition] of Teranga (Wolof hospitality)". Their restaurant represents an attempt to democratize the restaurant industry in The Gambia, with Gambian owners and operators, fair wages for employees, and profits invested back into the community. It also is indicative of the kinds of relationships that transnational communities produce and sustain - the marriage of American and Gambian food and hospitality cultures.

Suleiman too, after years of working in the U.S., ran into legal issues and was unable to renew his visa. He also was forced to return in the post-9/11 era. He returned to The Gambia with enough money saved to invest, and began a tire importing businesses. At the time, he states, European tires were very expensive, and had normally been used several times to the point they had very little tread left. He began importing lightly used tires from China and selling them at a competitive price so that Gambian drivers could purchase safe, affordable tires. Suleiman maintained this business for some time, but eventually sold it so that he could open an English language school in an outlying area of the capital. While public education is widely available in The Gambia, the public-school system, Suleiman argues, does not provide a good education. 
Children at public schools, Suleiman noted, "maybe only attend school one or two hours a day, and they are just playing... they come out of grade 8 and they still cannot read or write". Teachers' salaries are abysmal at the public schools, where they frequently bring home less than $\$ 60$ USD a month. On the other hand, private schools in The Gambia are often operated by overseas charities or wealthy expatriates, and they charge tuitions that most Gambians could only ever dream of paying. Suleiman opened a school in a community where he identified the need for higher quality education at an affordable price. He pays his teachers over twice the average salary they would receive in a public school, and rather than enrolling only upper-class Gambians, his students largely come from the surrounding community.

Migrating abroad has given many Gambians the skills, experience and capital they need to engage in transnational economic activities, start businesses at home and address needs in their immediate communities. Their businesses often operate in underserved populations, provide services at affordable prices, and circumvent ongoing systems of oppression and extraction by expatriate-dominated businesses. Their business models seek to address inequality and systematic barriers that keep Gambians from participating in their own market system. Embedded in transnational relationships, these activities represent not only the material benefits that migration can provide for The Gambia, but also an alternative approach to 'making it'. Rather than performing the signs and styles of a global capitalist order, these activities illustrate the new kinds of transnational cooperation and 'development' that can result from international migration.

\subsection{Conclusion}

The GNA transnational community exhibits, to a large extent, significant control over the way migration between The Gambia and North America is represented. Migrants, through both classical and "social remittances", social media, 'semestering' and public-facing interactions, often portray themselves as successful and respectable in interactions with people at home, reinforcing the narrative that North America is a place where people can go to 'make it'. Many uphold this narrative publicly, but challenge it in one-on-one interactions with loved ones, demonstrating the difficulties they faced while living abroad. While some, particularly the kinetic elite with access to class privilege and legal status, may be less than forthcoming about their difficulties, others, particularly those without legal status, are more candid about their many 
difficulties, compounded by a lack of legal status or finances, and encounters with racism in North American society. Those who encounter difficulties may not be as readily able to portray themselves as successful, as someone who 'made it', and their ability to re-integrate, or to stay in touch with family is compounded by migrants who do 'make it'.

Such narratives of success that uphold the signs and styles of a global order, however, are challenged by some in the GNA community who engage in transnational economic activities, start small businesses in The Gambia, and use their experiences as migrants to provide material benefits to their home communities. The way they show they have 'made it' does not revolve around smart-phones, fancy clothes and reproduction of the geographic imaginaries of North America. Their narrative of 'making it' combines the skills learned and resources acquired through migration with a dedication to overcoming repressive structures in The Gambia. 


\section{Chapter 6. Tekki Fii in The Gambia: Developmental Bordering and Immobilizing Discourses}

We are currently traveling around the country to explore an initiative called Tekki Fii, which means "Make it in The Gambia", and the name pretty much explains it all. What we are going to do is visit three different sites which are supporting local people in finding jobs in The Gambia.

Guillame Sanchez, EU Vlogger. (Faces2Hearts 2019)

Yes, it is possible to Tekki Fii, because right now I can say I'm already rich! I'm on my way towards that end. So, I believe that the more I push harder and then focus on my dreams of becoming an engineer, I believe that one day I will be an engineer, and that will lead me to my success, which means Tekki Fii can happen here in The Gambia.

Fatou Badjie, Tekki Fii Program Beneficiary. (ITC 2019)

As established in chapters 4 and 5, the phrase 'making it' is frequently mobilized by migrants in the GNA community and their families to discuss the success and lifestyle associated with international migration from The Gambia. In this chapter, I shift my analysis to include the discursive space inhabited by European actors who seek to shift and shape narratives about migration in The Gambia. European states and their representatives in The Gambia have also begun using the language of 'making it' as a counter-narrative to the one perpetuated by migrants as they attempt to reduce out-migration from The Gambia. This phrase has become associated with one EU funded project in particular: Tekki Fi, implemented by the Youth Empowerment Project (YEP). They use this language to illustrate, specifically to young people, that they can find success at home by starting small businesses and receiving micro-loans from European and American NGOs (YEP 2017). This project and others seek to decentralize migration as the only means that Gambians have for 'making it' and to shift the discourse associating success with international migration.

The Tekki Fii program is but one of many ongoing interventions in The Gambia that rely both on the logic of humanitarianism and the ideas of the 'migration-development nexus'. As I argue here, these projects represent an extension of EU bordering practices into The Gambia as part of what Frowd (2018) terms the "developmental border". These interventions, in addition to material bordering practices, attempt to shape the discourse associated with migration from The Gambia, specifically of lower and middle-class Gambians to the EU. Projects like Tekki Fii 
propagate a narrative of migration as a dangerous and desperate enterprise that will inevitably end with suffering at the hands of racialized smugglers and human traffickers in North Africa. They propose that through participation in these economic interventions, Gambians can avoid becoming 'victims', and 'make it in The Gambia' all the while obscuring Europe's own role in producing and sustaining structural violence through violent bordering practices, contemporary and historical colonial relationships, and constantly shrinking means by which Gambians can 'make it'. European agents' additional appropriation of the phrase 'making it' stands in direct contrast to the ways the phrase is used by the GNA transnational community: it shifts Gambians from an active agent in the process of 'making it' to a passive beneficiary of European humanitarianism. While this case study does not specifically focus on the lived experiences of Gambians who migrate to Europe, the salience of European actors' interventions in The Gambia necessitates engaging with the narratives about migration and 'making it' that they propagate. These narratives are a critical part of the discursive space within which migrants and their families make sense of and experience migration.

\subsection{The IOM and Developmental Bordering apparatus in The Gambia}

Non-governmental organizations, as I illustrated in the literature review, have gained importance under the relationships that Frowd (2018) terms the "developmental border". Chief among these in the Sahel is the International Organization for Migration (IOM). As Pécoud (2018) endeavored to show, the IOM has gained significant influence over migration policy and management - acting as both a representative and implementer of EU policies, and a contracting agent for African governments. The IOM's historically informal relationship with states and lack of transparency into its activities "makes for the impression that IOM is nothing more than a service provider to states, with little legal or political influence” (Pécoud 2018, p. 1622), obscuring the inherently political nature of its activities.

Since the IOM's consolidation as a permanent organization in 1989, it has gradually grown in size, budget and influence to the point that it has 173 member-states, a budget of over $\$ 1.3$ billion USD, and 11,500 full time staff around the world (IOM 2019). Much of this growth has occurred since 2016, when the IOM became officially associated with the United Nations. Now, governments are able to outsource many different kinds of migration-management to the IOM: the readmission and transport of migrants; assisting of displaced peoples; designing of 
migration policies; counter-trafficking measures; labor migration programs; training of government, NGO and media personnel; data collection and publishing; and the distribution of funds to other agencies to implement similar projects (Pécoud 2018). The IOM often situates these activities within the developmental rationale of 'capacity-building', wherein 'weak states' of the global South are given the tools, training and expertise they need to effectively manage migration flows, especially those identified as 'sending' or 'transit' states. These activities situate themselves as beneficent to migrants, but as Ashutosh and Mountz write,

"the IOM enforces the exclusions of asylum seekers and maintains the central role of nation-states in ordering global flows of migration. In addition, we argue that the IOM acts on behalf of nation-states by using the language of international human rights, as though working in the interests of migrants and refugees" (2011, p. 1).

While the IOM alludes to humanitarianism and the rights of migrants, their activities often complement the territorial bordering practices of nation-states, and de-politicize the work of migration governance. The logic under which the IOM operates also upholds the same kinds of 'top-down' discourses that situate the EU as 'under threat', West African states as 'in need of intervention', and migrants as 'victims in need of humanitarian assistance'. These discourses, Frowd (2018) argues,

all contribute to a turn - especially within the IOM - to a new form of 'borderwork' that is broadly developmental in that it brings together these divergent rationales in complex ways. The IOM's developmental turn retains work around sovereign borders as its raison d'être, yet its conception of managing them brings together logics and modes of intervention from the worlds of security, development and humanitarianism. (p. 4)

The IOM has collected data in The Gambia since 2001 as part of its broader migration management activities, but its more intensive projects did not begin until it opened a Gambian field office in 2017. Through its increased presence and activity in The Gambia, the IOM has become a powerful player in that it not only influences policy, but the discourse surrounding migrants and migration from The Gambia. As the representative of the EU and other states of the global North, the IOM and its implementing agencies are able to project European narratives about migration and the ideas of the 'migration-development nexus' into the Gambian discursive climate. Here, I detail three ongoing EU-funded, IOM implemented projects that manage migration and utilize immobilizing discourses which arguably extend the EU's border into The Gambia. 


\section{1a “What kind of choice is that?" - IOM's AVRR Program}

The Assisted Voluntary Return and Reintegration (AVRR) project has existed since 1979 as a means to help migrants return to their 'country of origin' after having their asylum request rejected, becoming stranded in a 'transit state', or if they have been trafficked (IOM 2015). While AVRR services are available in many parts of the world, IOM staff involved in the AVRR project in the Sahel operate field offices in Tripoli and other Libyan cities wherein migrants who wish to return to their countries of origin can request to be returned via charter flights. IOM typically provides initial health screenings for those who wish to return, provides transportation costs back to their home, and often provides some reintegration services upon arrival, including food items, counseling and job-training programs. If a migrant's travel documents were lost or stolen, then the AVRR will acquire temporary ones for a migrant's journey home (IOM 2019).

To be certain, the AVRR is an important service for many migrants who find themselves stranded and out of money to pay smugglers after a long journey across the desert. Some may be imprisoned by Libyan police, ill or injured from the journey or from clashes between government and rebel forces. Others have been tortured by smugglers for their inability to pay trafficking fees. The participants I spoke with who had utilized the AVRR's services indicated that they were eternally grateful for the opportunity to come home after everything that had happened to them. One participant I spoke with indicated that she may have died in Libya had the IOM not allowed her to return:

My kidneys had failed. You see... because [the smugglers] would sell water to us in the desert to drink, so I don't drink enough water for so long that I start to have this problem with my kidneys. I had to go home, there was no way for me to stay there and attempt that crossing to Italy.

The AVRR provides much needed services to people who have run out of options and must return home. However, situating smugglers as the enemy against which humanitarian forces must fight obscures not only the reasons why migrants left The Gambia in the first place, but the perilous nature of the journey created by bordering practices. Those who take the "Back Way" through Libya do not have the same class privileges or family connections as those in the GNA transnational community. Going to North America is not an option for them. If they want to 'make it', amidst ever-shrinking means to do so in West Africa, they must risk it all to get to Europe. As Abulie exclaimed to me one afternoon: 
You know why [people take the 'back way'? Because people within cannot do it. A salary of a highly qualified teacher in this country is less than $\$ 100$ a month. For someone who has a wife, has kids, has parents to take care of, has family needs, has social needs, has cultural needs, other obligations. Wants to build a house, wants to buy a car, wants to pay transportation. Wants to feed everyone, wants to do healthcare. It's impossible. It's impossible. So, his choices are stuck. Either be corrupt, or emigrate, or do something illegal, or figure it out yourself, or die. I mean if you have these choices to make, I think, easiest among these choices, is to let me leave. Even if I die outside, it's worth the price.

With these options available, as participants widely indicated, most Gambians would be happy to risk their lives crossing the desert in the hopes of 'making it' for themselves and their families. But as Europe's borders become increasingly hardened, militarized, and migrant routes into Europe become increasingly dangerous, the drive to 'make it' has resulted in more violence and death at Europe's borders. The AVRR program, despite providing much-needed services to those who fall victim to these violent borders, does deeply political work in the service of territorial borders. Acting as a means to 'sweep up' those who become stranded and to relieve suffering caused by the ever-present and racialized North African smuggler, the AVRR situates itself as doing humanitarian work while at the same time continuing to allow hardened, militarized borders to function in an age of increased public scrutiny of violence.

While this return service is cloaked in notions that migrants "voluntarily" choose to go home, one young man named Momodou, who spoke with me about his experience with AVRR indicated otherwise: "They say I am a voluntary returnee, but I had no choice. It was either come home or die there in Libyan prison. What kind of a choice is that? Of course I chose to come home." While Momodou never, in fact, reached Europe's borders due to the erosion of visa policies and the hardening of more easily accessible routes into Europe, he still became a victim of violent bordering practices after having been imprisoned by Libyan police for nearly a year. In this case, the AVRR did the EU's work of keeping Momodou from reaching the border, while at the same time portraying this repatriation as an act of humanitarianism.

This is to say nothing of the reasons migrants attempt to reach Europe. While the two returnees I interviewed indicated they had traveled for "economic reasons", the reasons migrants have for the journey are varied and complex. Many flee famine, political persecution, domestic abuse and sexual violence. Historically, those from this region who reach Europe's shores have been treated as "bogus refugees" (Neumayer 2005), their reasons for seeking asylum reduced to 
the economic. The IOM's humanitarian mission of returning migrants to their home countries obscures the question of what they are returning them to. In the case of asylum seekers, these "voluntary return" programs may be another form of neo-refoulment (Hyndman and Mountz 2008), where asylum seekers, not only through altered state geographies, but by the action of non-state actors on behalf of the state, are prevented from accessing sovereign territory upon which they can make an asylum claim. The IOM's work of situating all migrants from the Sahel as economic ones seeking work in Europe, not refugees, paints broad strokes over the multiple forms of structural violence migrants experience that leads them to try 'making it' in Europe. Caught up in these strokes may be refugees, who are then refouled back to whatever form of persecution or violence they had originally escaped.

The IOM's AVRR program, despite its beneficence, does the political work of returning migrants back to their 'countries of origin' for the EU, all the while maintaining that its activities are humanitarian in nature, intended to prevent death and alleviate suffering. It's stance as an apolitical entity, operating in the interest of humanity, allows the IOM to continue its work, while widely being regarded as an objective and humanitarian entity.

\section{$6.1 b$ “That program was not what I needed" - YEP and Tekki Fii}

The IOM, as part of Europe's mission to 'solve' the 'push factors' that influence migration flows, has recently begun to support a number of smaller projects that list such goals as economic empowerment, job skills training and entrepreneurial support. YEP and Tekki Fii are joint programs between the Government of The Gambia, IOM and the International Trade Commission, funded by the European Emergency Trust Fund for Africa, that attempt to provide economic development to reduce out-migration. YEP combines micro loan financing for young Gambians with skills training, "capacity building” and community development (YEP 2017). Gambians between the ages of 15-35 are eligible to receive vocational training for 4-6 months and a small loan of up to $\$ 1,000$ USD upon completion. The program ostensibly attempts to alleviate poverty through self-employment of beneficiaries, and the hope that beneficiaries will in turn create jobs for others. While not explicitly a part of the AVRR program, many of those returned through AVRR to The Gambia are then subsequently enrolled in YEP. In an interview I conducted in 2019, one IOM official felt that the YEP program had been somewhat successful, 
in that "some returnees have started their own small local shops, like small convenience stores, others are into tailoring, others are into poultry as well”.

While YEP focuses on the "capacity building” aspect of IOM's goals, Tekki Fii focuses more on public engagement and "sensitization" to the dangers of 'irregular' migration and the potential alternatives that are available. Tekki Fii's primary activity is identifying young, successful Gambians, showcasing their small businesses and projects, and using their faces and personalities to spread the message that "you can make it here" - to avoid taking the back way, and instead stay in The Gambia and start a small business. Their primary media are billboards (see Fig. 1) around the capital area, a radio show where staff interview young people, and occasionally public programs where beneficiaries of YEP speak. Not all of the successful youth that Tekki Fii showcases are YEP beneficiaries, but it is often implied in the messaging that they received some support from IOM or other European entities. One billboard, for example, shows a young Gambian man lovingly holding a broiler chicken, with the caption: "Muhammed Sanyang; Poultry Farmer; Age 24; West Coast Region; From 5 to over 28,000 chickens; Now he employs 26 people - You Can Make It Here” (see Fig. 2). His image is ringed by the EU flag and the logos of the IOM, YEP and the ITC. While the billboard does not explicitly state that Muhammed received funding from YEP, it implies that his success is due to intervention by the YEP project. Muhammed Sanyang, in fact, achieved success in The Gambia before the IOM established an office or the YEP project began. He was originally a beneficiary of the U.S. Embassy's Startup Incubator (SIG) project in 2015, where he received considerable funding to grow his broiler chicken operation (SIGambia 2019). He then was able to grow his operation to its current level from revenue generated from the original startup funding. While Muhammed's success should undoubtedly be celebrated, and his path is an example of what a young, hardworking person can accomplish, his story is exceptional, and is not typical of YEP beneficiaries. YEP's use of his image and story implies that YEP beneficiaries will have access to the same training, resources and grant funding as Muhammed did. SIG recipients must have some proven track record of business management and the ability to write a grant that is persuasive to American embassy staff - skills that most young Gambians who YEP targets do not have. Interviews with YEP beneficiaries reveal further the kinds of training and support available through the program. Mehmet, a young man who hoped to go abroad for work, but instead decided to enroll in the YEP program noted that "the program I went for was electrician 
training. It lasted six months, but it was not very useful. They don't have laboratories to properly train you, they don't even have materials to show you how to do the things they teach you".

Momodou, who had been deported from Libya, also took an electrician training course from YEP as part of his reintegration program, and corroborated Mehmet's feelings about the efficacy of the program overall. He elaborated that

These programs have mixed success. Some of my friends who did the plumbing and hairdressing program, now they are doing well. But for me, that program was not what I needed. These agencies, they need to do their assessments properly before they just start doing projects.

At the conclusion of the training programs, YEP advertises that it gives out small starter loans or grants for the trainees to then go begin a small business. Ostensibly, the beneficiaries become small business owners and gradually expand the business to hire others, increase waged employment and achieve the kinds of reductions in migrant flows that European funding agencies seek. Mehmet noted that he received 2,500 dalasis (\$50 USD), which was not even enough to purchase the tools he needed to start a business, much less actually rent a storefront or begin operations. Momodou also received a small loan of less than \$50 USD explained that "At the end of the training, sometimes they give loans of 50,000 dalasis (\$1,000 USD), but most trainees are not eligible for these. You have to have some sort of business background, and most of us do not". Upon completing the program, Momodou was asked to participate in the Tekki Fii public awareness campaign:

They wanted to put me on a billboard because I received this training, and because I am well known. I declined, because what they gave me was not very much, and I don't want others to think that if they participate, they will have something from the program

While the YEP project does provide successful training for some people, many of its programs do not actually meet the needs of the participants, and the grants they receive at the end are much lower than what YEP advertises. Others in The Gambia have been broadly critical of the IOM and these kinds of programs, that they mostly serve the goals of the development agencies who implement them, rather than addressing critical needs on the ground. In a public "Street Debate" on migration (see Fig. 3) aired on the Deutsch Welle (DW) German Network, public minister Momodou Sabally stated:

The EU projects, all they are interested in is a few success stories that they can brand and put on billboards in the country, nothing is being done here. This country is not ready, is 
not able to handle these returnees (DW 2019).

Another speaker, Professor Ismaila Ceesay noted that both the Gambian government and the EU implementing agencies often reduce migration to economic reasons

European countries have their own interests, and African countries have their own interests... we have known the problem exists, but why? We always focus on the economic aspects of it. There are socio-cultural aspects to this problem. How do we solve these problems? (DW 2019).

Despite mixed reviews as to YEP and Tekki Fii's efficacy at actually helping to put young Gambians to work and reducing out-migration, these projects reinforce the notion that migration from The Gambia is largely an economic issue that can be resolved through economic development interventions, and they obscure the EU's ongoing project to restrict or eliminate access to the European continent through the language of beneficence and humanitarianism. Much less, they also fail to address structural issues that prevent young Gambians from getting ahead and 'making it'. Abulie illustrated this with the example of broiler and layer chicken production - an area that YEP trains young people on:

We've tried to create [jobs for] young people by training them. We claim to give them jobs. We give them jobs that don't give them money. And we are back to ground zero after 3 years. I bet you if you come back 5 years after the Tekki Fii program, I bet you almost $90 \%$ of the trainees should have been down (out of business) already. I give you an example. Yesterday I visited 3 farms. One of them has 30,000 chickens. 20,000 are layers, 10,000 are broilers. The other one has 2,000, or 2,500 broilers. They have gone beyond maturity. Now everyday he feeds them is a waste. And how is it acceptable that this country still imports chicken. It's ludicrous.

The farms that Abulie visited were projects started by young people as part of YEP or other EU funded projects, with the idea that if they worked hard and built their business, they could 'make it' and hire more young people to reduce out-migration. What Abulie alludes to in that they have "gone beyond maturity", however, is the difficulty of selling locally produced chickens or eggs in The Gambia. People normally only purchase these chickens for special occasions or for ceremonial purposes because frozen, imported chicken legs from the U.S. can be sold far below what Gambian poultry farmers can afford to sell their broilers for. Imported "Grade B" eggs from the Netherlands, which are widely available on every street corner, are sold for far less than a local egg. The poultry farmer, despite having 'made it' on paper for a European funder's purposes, is not successful in the long run - they cannot actually sell their product or grow their 
business because of exposure to competition within the global marketplace - often from the same regions that go to such great lengths to control and criminalize migration. While IOM has 'saved' beneficiaries from the highly visual forms of violence inherent to the 'Back Way', they could not save them from the structural violence of the global economy that made them want to leave The Gambia in the first place. And, as Abulie concluded, if "[the poultry farmer] leaves today (for Europe), I'm not going to blame him. Because he has done everything that we ask him to do". Perhaps the IOM did not save the beneficiary at all, if the farmer, having failed at starting a business, decides to travel to Europe three years later.

Projects that, on the surface, preach self-help and success stories, do the political work of dissuading youth from attempting to journey to Europe. Simultaneously, they further a seemingly a-political discourse that 'making it' is possible in The Gambia with European assistance, without actually engaging with all that the term means and the assemblage of forces conspiring to keep Gambians from 'making it' at home.

\section{1c "Funding has really taken off for migration" - The IOM Development Fund}

It is not only European agents, or Europeans directly employed by the IOM who are active in promoting European visions of migration management in The Gambia. While the IOM traditionally works directly with and for state governments, recently they have begun to fund other NGOs and charities to perform different types of development interventions in the interest of migration governance. Of particular interest here is the IOM's Development Fund, which provides small grants (up to $\$ 300,000$ USD) to implementing agencies in states throughout the global South. Through this program, the IOM is able to expand its activities to include projects such as grassroots organizing, sensitivity and sensitization, and public awareness through a variety of small organizations which diverge from the explicit security focus of IOM's northern member states. Many of these small grant recipients are Gambian-run and managed organizations that offer salaries far beyond those normally found in The Gambia. While programs like YEP may provide dubious benefits at best for young Gambians, these projects do, on the other hand, provide continued employment and funding for not only European funders and executive agencies, but a host of smaller, Gambian implementing agencies that manage projects. While there has existed a 'bureaucratic class' of Gambians who work in the development industry since Gambian independence in 1965, a recent flood of funding for 
migration-related projects has expanded this class to include Gambian 'experts' on migration management. As the director of one such charity indicated, "funding has really taken off for migration [projects]. Now it's all about migration and climate change". These experts, who often received their education in the EU or North America as a prerequisite for employment in the development sector, are often the strongest proponents of immobilizing discourses.

The relationship between the Gambian bureaucratic class and lower-class Gambians who hope to migrate to Europe reveals the contradictions inherent in the term 'making it', and how European agents attempt to control the term. Jeneba's plans to become a 'migration expert' help to illustrate this. As a university student in The Gambia, Jeneba dreams of going abroad to finish a masters' degree in North America before coming home to work at one of the agencies currently implementing EU-funded projects to reduce migration:

“... if I have my master's, I would like to work for my country, if I can work for my government, at least to have... to influence on the youths and educate people about... sensitize people to be educated and lessen this migration, that they can make it in the country, in our country."

While Jeneba's desire to join the echelons of society responsible for implementing these kinds of projects - the bureaucratic class - require her first to go abroad and get a foreign diploma. For her, 'making it' is linked to upward class mobility and employment in the development sector, which she indicated is unattainable without international migration:

It's frustrating sometimes, because even now they don't [hire someone] if they have a bachelors' in The Gambia. If someone is going abroad and they have their [diploma] from there back to The Gambia, they will have the job. No one from UTG (the University of The Gambia) will get it.

Jeneba touches here on the fact that the implementing agencies almost exclusively hire upperclass Gambians who had access to international mobility in the first place and received a bachelors' or masters' degree from universities in North America or Europe. Jeneba's need to go abroad in order to achieve the kind of career she wants further reinforces the narrative that 'making it' is linked to international migration. After returning to The Gambia, 'experts', such as Jeneba hopes to become, then find themselves producing and reinforcing the immobilizing narrative that 'making it', for lower class Gambians, can only be accomplished by becoming a beneficiary of European development interventions. Thus, European states and their agents simultaneously reinforce the 'making it' through migration narrative for the Gambian upper-class 
by making employment in the development industry contingent on having a foreign diploma, all the while assuring lower-class Gambians that the best way for them to 'make it' is to stay at home.

\subsection{Youth activism on migration - the case of YAIM}

The discourse about Gambian migrants going to Europe has, for much of the past decade, been shaped by European entities ostensibly operating on behalf of the Gambian Government. From early characterizations as "criminal" to that of "irregular", to that of "victim", these representations of migrants have flowed from European centers of power down through the hierarchical structures of executive and implementing development agencies to the streets and compounds of The Gambia. Just as migrants from the GNA transnational community and other regions of the world have been demonstrating their success through remittances and the language of having 'made it', European actors have subsequently been establishing these negative discourses of migrants who go abroad in the hopes of 'making it', all the while actively working to eliminate the means by which to safely and legally migrate. The narrative of migration in The Gambia has been largely shaped by those actively trying to immobilize Gambians at home, or a privileged class of Gambians who were able to migrate themselves. One small group of returnees, however, have begun to challenge the existing social relationships that shape representations of migration in The Gambia. This group calls themselves the Youth Against Irregular Migration, or YAIM. Just as IOM and other European actors do, YAIM spreads a message to Gambian youths to not attempt the 'back way', but their message comes from the perspective of those who made the journey themselves and came home to raise awareness of the dangers, not of those hoping to immobilize Gambians as part of a European bordering strategy. I spoke with a young man, named Selbay, who is a member of YAIM and heavily involved in their public outreach mission.

Selbay took the 'back way' in 2015 and made it all the way to Libya before being arrested by Libyan police. He was out of money, and exhausted from the journey at this point. He found himself in prison with a number of other young Gambians, who were also ill or injured, out of money, and homesick. He explained to me that:

At that point, we were in prison for some months. We resolved that by any means we could, we would make it home, Insha'Allah. That day we established YAIM and committed that if we ever made it home, we would tell other young people about how 
dangerous this journey is.

Selbay and the other YAIM members were brought back to The Gambia by IOM's AVRR. After arrival, the majority enrolled in the YEP program. They began to undertake their mission of spreading awareness of the dangers of the 'back way' journey. Starting with small public programs in the capital area to spread awareness and tell their stories, their group was discovered by IOM and given small amounts of funding to expand their project. They began to put on 'road shows', where they drive up and down both sides of the country, making stops in targeted communities along the way. Their shows usually involve speaking to groups of upper level students at public schools, holding community meetings to discuss migration, playing pick-up soccer games to engage other youths, playing music and broadcasting their messages over loudspeakers, and holding documentary film screenings.

As indicated by a number of interviews with developmental borderwork practitioners, YAIM's programs have been among the most effective, because it is run by Gambians who actually took the 'Back Way'. One Gambian who had gone abroad for a master's degree and is now employed by IOM noted that:

It's always difficult sending out whatever message to [potential migrants]. Especially coming from people like us, people who have gone out, studied and come back. They look at you as like, 'why should you want to talk to me when you also went out of the country?'

YAIM presents the same message that IOM preaches, but from the perspectives of Gambians from a lower class who did not have access to international mobility, and who actually suffered through the journey and experienced Europe's violent borders firsthand. This is a powerful medium through which to raise awareness of the dangers of this route. An official from another Gambian charity group lauded YAIM's work, saying:

[Our] programs have met with some resistance from youth who say, 'come rain, come shine, I will still take the back way.' But after presentations by YAIM, when given a follow-up questionnaire, many youths changed their minds.

Selbay noted that there has been a drop in the number of young Gambians taking the back way since they began their public engagement projects in 2017. Clearly, the strategy of public engagement by young Gambians has resulted in the kinds of outcomes that IOM, European governments and NGOs are looking for, but as Selbay mentioned, they have more recently encountered issues working with these entities. IOM stopped funding their road shows earlier 
this year. They were able to secure support from an Italian charity called Cooperazione Internezionale (COOPI) to continue these projects, but with only minimal funding. They also began hosting a radio talk show wherein they could showcase their stories and those of other migrants, which had some success, but after IOM and YEP refused to support the radio show, and went on to start their own radio program, YAIM was forced to cancel their show. Selbay expressed frustration about working with the European agencies, both IOM and COOPI: "When I go to the steering committee meetings, I am the only person who doesn't have a car, who isn't wearing a suit. When I talk there, no one wants to listen to me".

Young Gambians like Selbay and those involved in the YAIM group are successfully doing the work of discouraging other would-be migrants from taking the dangerous routes towards Europe. Why then do organizations like IOM fail to support, and in some cases undermine, such 'grassroots' activities when many consider YAIM's activities to be successful and IOM and YEP's activities to be a waste of resources? While Selbay maintains that IOM or COOPI have never asked them to modify their messages, perhaps there is fear on the part of European officials that they do not have full control over YAIM's message and activities. Indeed, endorsement of YAIM's activities would imply a degree of agency and ability on the part of Gambians, a notion that development practitioners often pay lip-service to, but that conflicts deeply with the development industry's belief of a lack of 'capacity' in African peoples - especially those who were not educated in Europe or North America. The situation of young Gambian migrants as protagonists in their own attempts to raise awareness of Europe's violent borders perhaps also interferes with humanitarian and Euro-centric visions of migrants as in-need of care and intervention to prevent death and alleviate suffering. In this sense, YAIM's attempts to reshape dominant narratives about migrants amidst all of the efforts to control, immobilize and 'develop' them turns the narrative Europeans have crafted about African migration on its head it shifts Gambian migrants from victims in need of 'saving' to agents who attempt to carve out a place for themselves to 'make it' in whatever way they see fit despite massive efforts to silence and immobilize them.

\subsection{Conclusion}

European actors have appropriated the language of 'making it' as part of broader attempts to extend Europe's bordering practices into The Gambia, keep lower-class Gambian migrants at 
home, and shape the meanings attached to migration in The Gambia. European non-state actors, particularly the IOM, marry the logic of humanitarianism with the mechanisms, hierarchies and funding structures of the development industry to extend bordering practices into The Gambia to immobilize lower-class Gambians before they ever begin their journey towards 'making it'. These practices, while outwardly a-political, do the work of enforcing Europe's borders, returning migrants to their 'state of origin' despite their reasons for leaving, while obscuring Europe's violent bordering regime by situating North African smugglers as the primary perpetrators of violence. Using the ideas of the 'migration-development nexus' as inspiration, these actors implement an array of economic interventions designed to solve the 'push factors' of poverty and joblessness. These economic interventions are accompanied by public-outreach campaigns, such as Tekki Fii, which attempt to shift the discourse around 'making it' to involve passive acceptance of European developmental aid, rather than migration.

While European actors have taken a lead role in this developmental borderwork, new funding strategies by the IOM have paved the way for smaller Gambian organizations and their upper-class Gambian employees to enter this discursive environment, albeit as kinetic elites who then become complicit in the process of attempting to immobilize the lower class. European states and their agents have been highly influential in shaping the discourse around migration and 'making it' in The Gambia. But despite their dominant narrative, there are small groups like YAIM who try to shift the narrative around migration and 'making it' to account for their own lived experiences as migrants. 


\section{Chapter 7. Conclusion}

Allow me to return, for a moment, to the vignette I presented in the introduction: a group of twelve deportees stepping off of a plane from Germany; a flight full of 'semesters' taking off to return to the U.S. Both present wildly different forms of mobility; that is, the varied meaning given to human movement. The returnees are represented, largely by European actors, as "illegal", "undocumented", or as "refugees". They are people who tried to 'make it' and were spit out by the European bordering apparatus. The semesters are represented, largely by themselves, as successful, elite, and highly mobile: as people who 'made it'. Over the course of this project, I have worked to destabilize these representations and discourses about migrants in The Gambia, to illustrate their relation to the ways movement is experienced, and to reveal the roles of various actors in shaping them, especially European governments and NGOs. Here, I briefly recap this project's findings.

\subsection{Summary of Results}

In Chapter 3, I use language introduced by participants about 'waves' of migration between The Gambia and North America to explore the different and shifting ways GNA migration has been represented and given meaning. This illustrates that, as Cresswell (2006) explains, the relationships between meaning, movement and the practice of movement are not static and but rather change over time. While this is not a comprehensive or exhaustive study of these shifts and historical and varied meanings, interviewees discussed three different 'waves' in how the GNA community has been represented: as seasonal traders and students; as longer-term labor migrants looking to settle down; and as a part of a broader shift in viewing migrants as 'security threats' after the September $11^{\text {th }}$ attacks. I then established that as a result of the challenging legal and discursive landscape in the U.S. following 9/11, the GNA community increasingly views Canada as a more welcoming destination.

In Chapter 4, I introduced 'making it' as a contested term and illustrated how the phrase has been used to refer to migration in the GNA community. I explored how 'making it' is often conceived of with regards to geographic imaginaries about North America that may be shattered when migrants arrive. I used an intersectional analysis to explore how the categories of race, class, gender and legal status impact and shape migrants' embodied experiences in North 
America. In general, I found that migration to North America was often predicated upon upperclass status in The Gambia, but that migrants often experience a drop in class-status while living abroad. Additionally, Gambians must navigate unfamiliar North American racial formations upon arrival. This results in an increased awareness and policing of one's own actions so as to "conform" to a category that participants described as "proper behavior". Legal status confounded both of these categories to an extent - those without legal status may have experienced the drop in class status and unfamiliar racial formations more viscerally than others because the kinds of jobs or economic activities they had access to. Men without legal status may have had a more challenging time adapting to the kinds of service jobs available to them without documents - jobs that Gambian men often consider to be 'feminine'. Women, particularly those who wore headscarves, experienced anti-Muslim sentiments more so than men because of their increased visibility as Muslims. 'Conforming' to what they considered 'proper behavior' within North American racial, class and legal structures, and 'staying below the radar' are strategies that migrants developed to 'make it' in North America.

The GNA is a transnational community whose continued ties with loved ones at home, aspirations to return and sense of belonging in multiple places, span state borders and challenge 'methodological nationalism' in migration studies. In Chapter 5, I used the lens of 'making it' to explore how the GNA community represents their experiences of migration to loved ones at home through cash remittances, social remittances, 'semestering', charity, and other visual displays that embody the 'signs and styles of a global order. These displays of success form, I argue, a dominant narrative of what 'making it' in North America looks like - a narrative that is perpetuated in public-facing interactions. Migrants, however, challenge this narrative in more private interactions with family members where they nuance the 'signs and styles' through discussion of the difficulties they faced. However, GNA migrants do not all have the same ability to represent their stories - those without money or legal status are unable to represent their experiences to the extent that the more privileged can. The discipline they experience for failing to embody the dominant narrative of 'making it' can result in intimate impacts on families - misunderstanding, frustration and even 'cutting ties'. Finally, I demonstrated how some members of the GNA community engage in kinds of transnational economic activities that challenge the dominant narrative of 'making it' because these activities embody cooperation rather than the signs and styles of a global order. 
The case study of the GNA community is deepened through examining migration discourses within The Gambia itself, where European actors play a major role in shaping the discourse about migration. As I examined in Chapter 6, European actors have appropriated the language of 'making it' in attempts to shape the discourse about migration in The Gambia. Tracing the IOM's activities in The Gambia, I illustrated how these attempts are embedded in broader European bordering practices that rely on humanitarian logics: they depoliticize the violence of Europe's borders while situating North African smugglers as perpetuating violence against migrants. I detailed three different programs that the IOM currently implements in The Gambia to illustrate how in addition to their material intervention strategies, they also attempt to shape representations of migrants. While European bordering practices situate migrants as 'victims' who must be 'saved' from smugglers, the novel 'developmental bordering' apparatus, embodied by the IOM, extends Europe's borders into The Gambia. The IOM's activities enact the ideas of the 'migration-development nexus' to further their own narrative of 'making it': staying at home and becoming a beneficiary of European-funded development interventions. However, the IOM contradicts its own narrative about 'making it' in that it reinforces classboundaries that require Gambians to receive an education abroad to achieve upward class mobility in The Gambia. Finally, I present the case of the Youth Against Irregular Migration, a youth activist group whose activities, while seemingly in-line with the IOM's dominant, immobilizing narrative, actually challenge it by re-centering migrants as those representing their own experiences and making decisions about how to 'make it'.

\subsection{Theoretical Contributions}

This thesis uses the logic of mobilities to reveal not only the intensive efforts European states and their agents take to control both the practice and representation of migration in The Gambia, but also hierarchies and struggles for representation within the Gambian migrant community itself. This case study of the GNA transnational community cuts through the top-down discourses perpetuated by European entities to reveal how power impacts upon migrants in multi-scalar and, often, intimate ways. It is especially attentive to the transnational scope of power in its use of a multi-sited case study to examine migratory patterns across space.

This is a novel approach within migration studies in West Africa, augmenting more economic, quantitative studies (Kebbeh 2013, 2014), gendered analyses of remittance economies 
(Wong 2006; Babou 2008; Prothmann 2018), and political economies of migration governance (Langevang 2008; Altrogge and Zanker 2019). As a qualitative exploration of experience, representation and power across transnational spaces, the case study draws attention to the shortcomings of single-sited analyses of migrant communities where researchers' focus on a single space may miss how identities morph and change as people move.

This thesis, furthermore, expands on what Cresswell (2006) refers to as the "diverse array of representational strategies" (p. 3). While Cresswell and other mobilities scholars have focused primarily on material representations, such as film, literature, media and government policies, this thesis draws attention to geographic imaginaries as representations of mobility. This is notable in that while literature, films and the like are often created by people who are not migrants themselves, geographic imaginaries, while heavily influenced by media external to migrant communities, are products of migrant communities.

This thesis also contributes to ongoing discussions in intersectional theory as to what kinds of categories of identity are necessary to examine when studying transnational migrant communities. Drawing on Crenshaw's (1991) initial definition of intersectionality, as well as subsequent adaptations of the intersectional framework by feminist geographers studying migration (Flippen 2014; Sinatti 2014; Mahler, Chaudhuri, and Patil 2015), this project demonstrates how intersectional analyses may be used not only to explore how identities impact upon lived experience, but also upon representations. The way that different identities intersect in migrant communities may not only make the act of migrating more difficult, but impact upon an individual's ability to represent their experiences to others. This study supports Flippen's (2014) assertion that legal status must be explored in any intersectional analysis of a migrant community

This study also contributes to efforts to document the intimate impacts of bordering practices on migrant and transnational communities. Just as Mamadouh (2012) argues that bordering regimes have impacts across scales in Europe, the stories of participants in this project reveal that North American bordering practices work in and across scales, impacting both the individuals and their families - especially when a migrant is unable to secure legal status.

While transnationalism and the mobilities take similar approaches towards migration, this project specifically illustrates how representations, per the logic of mobilities, function within a transnational framework. Drawing on Salazar's (2011) work, it marries notions of the 
"geographic imaginary" with the mobilities paradigm to illustrate how not only material or discursive elements may be remitted through transnational networks, but also imaginings about 'migrant destinations'. In this light, transnational networks may form the spaces where dominant narratives are both produced and upheld, through the 'signs and styles of a global order', and simultaneously challenged and reshaped through activities such as transnational economic cooperation.

Finally, this project makes significant advances in illustrating the novel alliance between territorial bordering practices and the development industry. Following closely on Frowd's (2018) analysis of the IOM in the Sahel, it illustrates not only how these practices shape migrant flows and experiences, but also the discourse about migrants, particularly in 'migrant sending' states. Furthermore, this project contributes to the ongoing task of examining the workings of the IOM as a non-state actor with significant influence over migration policy, governance and discourse. This project goes further, however, in showing the multiple scales at which these geopolitical interventions occur, and the intimate spaces in which the IOM enforces the European border in The Gambia.

\subsection{Future Questions and Research}

This project does not pretend to be a definitive or comprehensive study of Gambian migration in general, or the GNA community in particular. Rather, it is an invitation to other scholars, journalists, policy-makers and activists to nuance the ways that migration is discussed and represented, in The Gambia and in other contexts. It raises important questions and lays the foundation for continued exploration of the relationship between movement, meaning and power - work that I hope to continue as part of a dissertation.

While I have hinted at gender as a category that intersects with race, class and legal status to shape migrants' experiences in North America, further work is necessary to elucidate exactly how migration in the GNA community is gendered and how gender roles are transformed in the process of migration. And while this project assumes Gambian nationality as a container of identity, further work may be done to situate Gambian migration as a part of broader West African migration to North America, and the GNA as a part of a broader African transnational community. 
This project makes some mention of non-human elements that move through transnational networks, such as money, goods, ideas and knowledges. However, the GNA community must be further embedded in transnational flows of humans, items, ideas and power between North America and The Gambia. This might include, for example, further analysis of the development industry in The Gambia and North Americans' and Europeans' international mobility as a development worker or 'expert'.

Development in The Gambia has been decidedly rural and agricultural in nature for much of the history of the small state as Carney (1993, 2009) and Schroeder (1999) show. But since their studies, the development industry has expanded to include many 'urban' projects in the greater Kombo area that target young, unemployed Gambians. These kinds of projects need to be detailed in order to illustrate how developmental bordering practices grew out of their existing infrastructures.

Finally, while I rely heavily on the stories of the GNA community for this analysis, nearly absent are the voices of lower-class Gambians who travel to Europe in the hopes of 'making it'. This is partially by design, so as to destabilize European narratives of 'crisis', but also because of my location in North America. Many journalists have engaged with Gambians stories of migration to Europe, but so often, these accounts paint migrants as helpless victims who need to be 'saved' by Europeans. To more fully engage with the relationships between movement, meaning and power in The Gambia, journalists, researchers and activists must make more concerted efforts to engage with Gambians living in Europe in ways that highlight their lived experiences while destabilizing the narratives of 'crisis' and 'invasion' that pervade explanations of the meanings behind their mobility. 


\section{Figures}

Figure 1. Tiga Tekki Fii Billboard

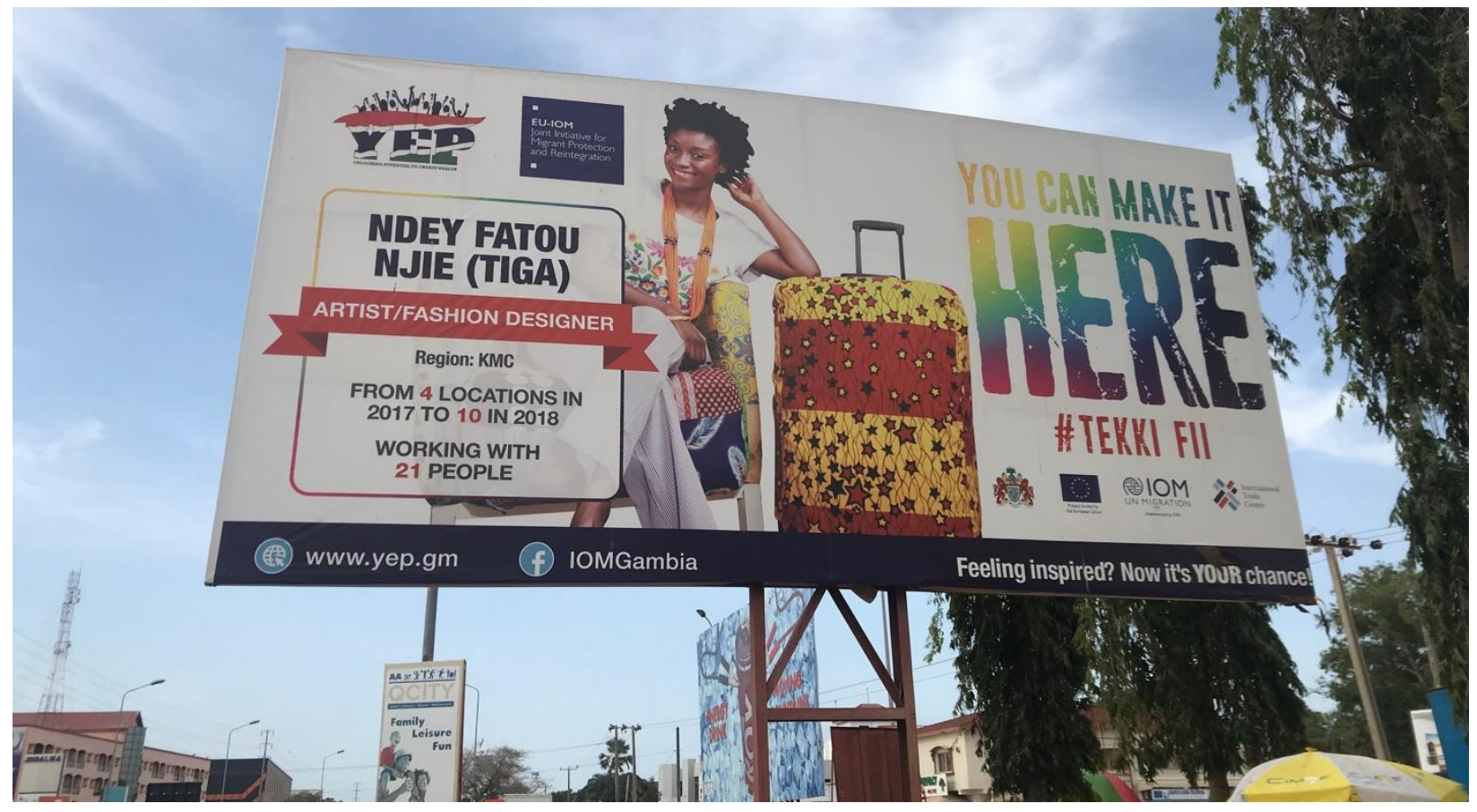

Martin Aucoin, July 2019

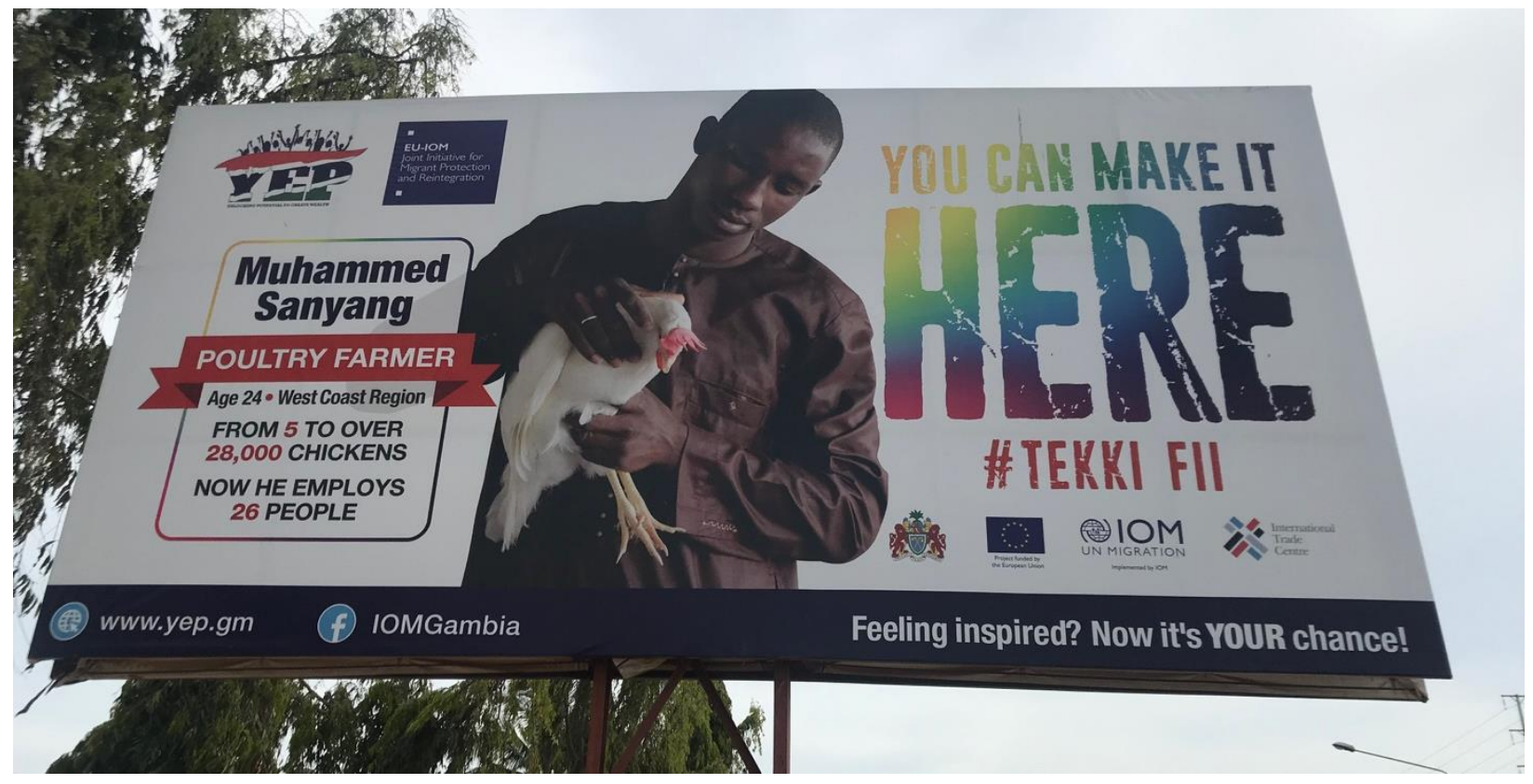

Figure 2. Sanyang Tekki Fii Billboard Martin Aucoin, July 2019 


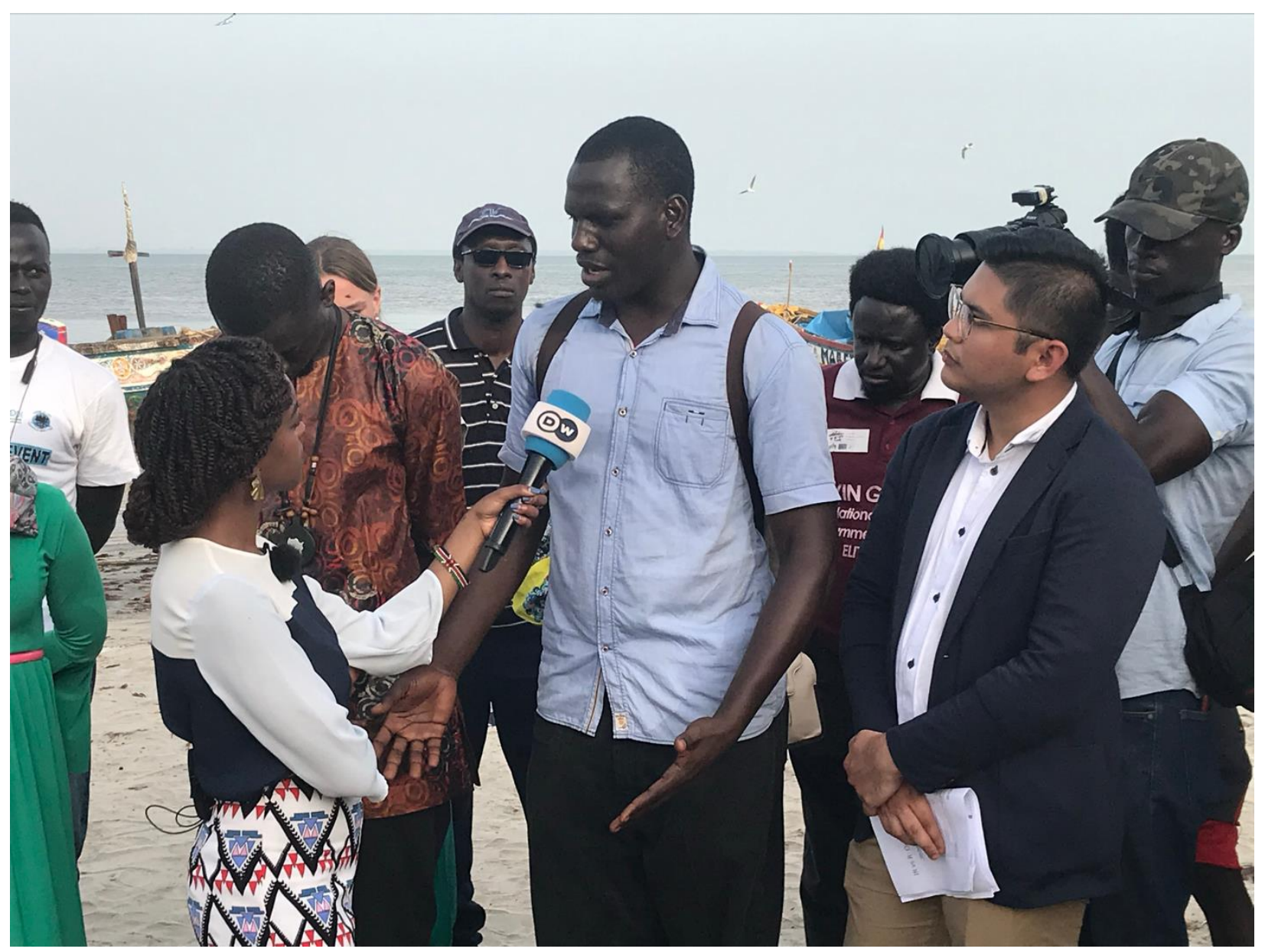

Figure 3. Deutsch Welle (DW) Migration Street Debate

Martin Aucoin, July 2019 


\section{Appendix A: Interview Guide}

IRB Interview Protocol

Migration and Development in The Gambia, West Africa

Protocol \#: 1903514326

PI: Dr. Cynthia Gorman

Co-I: Martin Aucoin

Questions for migrants residing in North America:

Can you tell me about the process of moving to the United States?

Why did you decide to move to the U.S.?

How did you choose which part of the U.S. you would move to?

Was it easy to adjust to life in the U.S., and/or find employment?

Do you enjoy living in the U.S.?

Do you plan to stay in the U.S.? Return to The Gambia? Go elsewhere? Why?

Do you maintain connections with family or friends in The Gambia?

Does your family or community in The Gambia benefit from you living in the U.S.?

How do you hope to benefit your family or community in The Gambia?

What is your hope for the future of The Gambia?

Is there anything else you would like to talk about? Any questions about the project?

Are there any other questions I should ask people about migration?

What would you like me to do with the results from this project?

\section{Questions for migrants who have returned to The Gambia:}

Can you tell me about the process of moving to the United States?

Why did you decide to move to the U.S.?

How did you choose which part of the U.S. you would move to? 
Was it easy to adjust to life in the U.S., and/or find employment?

Did you enjoy living in the U.S.?

Why did you decide to return to The Gambia?

Do you plan to stay here? Return to the U.S.? Go elsewhere? Why?

Did you maintain connections with family or friends in The Gambia while living in the U.S.?

Did your family or community in The Gambia benefit from you living in the U.S.?

How do you hope to benefit your family or community in The Gambia?

What is your hope for the future of The Gambia?

Is there anything else you would like to talk about? Any questions about the project?

Are there any other questions I should ask people about migration?

What would you like me to do with the results from this project?

\section{Questions for migrants who aspire to go to North America}

Tell me about why you want to migrate to the U.S.?

Do you think you will be able to move there? What challenges or barriers have you faced?

Are there any other destinations you have considered?

What do you think life will be like if you are able to go to the U.S.?

Which part of the U.S. do you want to move to?

Will you maintain connections with family or friends in The Gambia if you move abroad?

Do you think your family or community in The Gambia benefit from you working abroad?

How do you hope to benefit your family or community in The Gambia?

What is your hope for the future of The Gambia?

Is there anything else you would like to talk about? Any questions about the project?

Are there any other questions I should ask people about migration? 
What would you like me to do with the results from this project?

\section{Questions for family members who have relatives living in the U.S.}

Why did your relative decide to move to the U.S.?

Did they need your support to move there?

Does your relative maintain connections with you while they are in the U.S.?

Has your family benefitted from your relative working abroad?

How do you hope that your relative's work abroad will benefit you in the future?

What is your hope for the future of The Gambia?

Is there anything else you would like to talk about? Any questions about the project?

Are there any other questions I should ask people about migration?

What would you like me to do with the results from this project?

\section{Questions for experts or stake-holders in migration policy}

Will you tell me about your role or your organization's role in migration policy for The Gambia?

Can you tell me about the history of migration in The Gambia?

What activities are you/your organization currently conducting in The Gambia or the U.S. that relate to Gambian migrants?

How has migration from The Gambia to the U.S. affected The Gambia? The U.S?

Are there any policy changes you/your organization would like to see related to Gambian migration?

What is your hope for the future of The Gambia?

Is there anything else you would like to talk about? Any questions about the project? 
Are there any other questions I should ask people about migration?

What would you like me to do with the results from this project? 


\section{Appendix B: Coding and Analysis}

\section{B.1 Word Frequency Analysis:}

Criteria: 1) 3-character minimum word length; 2) includes stemmed words (eg. talking); 3) display 100 most common words.

From here, I sorted through the list of words to remove words such as "people", "like", "want" and "now". After removing these, I grouped similar words under a common, umbrella term, ex. "school", "university", "bachelors" and "diploma" were grouped together under the term "education", and "work", "employment", "business", and "job" were grouped together as "work".

\section{B.2 In Vivo codes}

From the word frequency analysis, I generated the following in vivo codes:

- Business

- Government

- Coming back

- Cutting ties

- Difficulties

- Education

- Work

- Making it

- Opportunity

- Money

- Papers (i.e. legal documents)

- Support

- Family

Using these, I conducted a preliminary coding of all interviews, notes and documents 


\section{B.3 Additional Thematic Codes}

After an initial round of coding, I re-read through all interviews, notes and documents to determine if I had missed anything important with the in vivo codes. I added the following thematic codes:

- Youth

- Elder

- Class

- Change of government

- Border

- Race

- Development

I combined the in vivo and thematic codes to conduct a second coding of all materials . 


\section{References}

About IOM. 2014. International Organization for Migration. https://www.iom.int/about-iom (last accessed 4 December 2019).

Adey, P. 2006. If Mobility is Everything Then it is Nothing: Towards a Relational Politics of (Im)mobilities. Mobilities 1 (1):75-94.

Ahmed, S. 2013. Strange Encounters : Embodied Others in Post-Coloniality. Routledge. https://www.taylorfrancis.com/books/9781135120047 (last accessed 21 April 2019).

Altrogge, J., and F. Zanker. 2019a. The Political Economy of Migration Governance in the Gambia. Mercator Dialogue on Asylum and Migration.

- 2019b. The return of migrants from Europe is causing problems for The Gambia. Quartz Africa. https://qz.com/africa/1751948/returning-migrants-from-europe-cause-problems-for-thegambia/ (last accessed 1 May 2020).

Andreas, P. 2001. The Transformation of Migrant Smuggling Across the U.S.-Mexican Border. In Global Human Smuggling: Comparative Perspectives, eds. D. Kyle and R. Koslowski, 107128. Baltimore: John Hopkins University Press.

Anthias, F. 2012. Transnational Mobilities, Migration Research and Intersectionality. Nordic Journal of Migration Research 2 (2). http://www.degruyter.com/view/j/njmr.2012.2.issue2/v10202-011-0032-y/v10202-011-0032-y.xml (last accessed 2 March 2020).

Asante, G., S. Sekimoto, and C. Brown. 2016. Becoming "Black": Exploring the Racialized Experiences of African Immigrants in the United States. Howard Journal of Communications 27 (4):367-384.

Ashutosh, I., and A. Mountz. 2011. Migration management for the benefit of whom? Interrogating the work of the International Organization for Migration. Citizenship Studies 15 (1):21-38.

- 2012. The Geopolitics of Migrant Mobility: Tracing State Relations Through Refugee Claims, Boats, and Discourses. Geopolitics 17 (2):335-354.

Babou, C. A. 2002. Brotherhood solidarity, education and migration: The role of the Dahiras among the Murid muslim community of New York. African Affairs 101 (403):151-170.

- 2008. Migration and Cultural Change: Money, "Caste," Gender, and Social Status among Senegalese Female Hair Braiders in the United States. Africa Today 55 (2):3-22.

Barglowski, K. 2018. Where, What and Whom to Study? Principles, Guidelines and Empirical Examples of Case Selection and Sampling in Migration Research. In Qualitative Research in European Migration Studies, IMISCOE Research Series., eds. R. Zapata-Barrero and E. Yalaz, 
151-168. Cham: Springer International Publishing http://link.springer.com/10.1007/978-3-31976861-8 (last accessed 1 May 2020).

Basch, L., N. Glick Schiller, and C. S. Blanc. 1993. Nations Unbound: Transnational Projects, Postcolonial Predicaments and Deterritorialized Nation-States 1 edition. S.1.: Routledge.

Blunt, A. 2007. Cultural geographies of migration: mobility, transnationality and diaspora. Progress in Human Geography 31 (5):684-694.

Boccagni, P., J.-M. Lafleur, and P. Levitt. 2016. Transnational Politics as Cultural Circulation: Toward a Conceptual Understanding of Migrant Political Participation on the Move. Mobilities 11 (3):444-463.

Boccagni, P., and M. Schrooten. 2018. Participant observation in migration studies: an overview and some emerging issues. In Qualitative Research in European Migration Studies, IMISCOE Research Series., eds. R. Zapata-Barrero and E. Yalaz, 209-225. Cham: Springer International Publishing http://link.springer.com/10.1007/978-3-319-76861-8 (last accessed 1 May 2020).

Böhning, W. 1994. Helping Migrants to Stay at Home. The Annals of the American Academy of Political and Social Science 534 (1):165-177.

Bolognani, M. 2014. The Emergence of Lifestyle Reasoning in Return Considerations among British Pakistanis. International Migration 52 (6):31-42.

Bondi, L., and J. Davidson. 2005. Situating Gender. In A Companion to Feminist Geography, eds. L. Nelson and J. Seager, 15-32. Malden, MA: Blackwell Publishing Ltd.

Borovnik, M. 2012. The mobilities, immobilities and moorings of work-life on cargo ships. Sites: a journal of social anthropology and cultural studies 9 (1):59-82.

Bostrup, J., and F. Frandsen. 2017. They know the risks and still they come: why young Africans chase the European dream. The Guardian 6 November.

https://www.theguardian.com/world/2017/nov/06/they-know-the-risks-and-still-they-come-whyyoung-africans-chase-the-european-dream (last accessed 27 March 2019).

Bray, D. 1984. Economic Development: The Middle Class and International Migration in the Dominican Republic. International Migration Review 18 (2):217-236.

Calavita, K. 2000. The Paradoxes of Race, Class, Identity, and "Passing": Enforcing the Chinese Exclusion Acts, 1882-1910. Law \& Social Inquiry 25 (1):1-40.

Campani, G. 1995. Women migrants: from marginal subjects to social actors. The Cambridge survey of world migration :546-550.

Caretta, M. A. 2016. Member checking: A feminist participatory analysis of the use of preliminary results pamphlets in cross-cultural, cross-language research. Qualitative Research 16 (3):305-318. 
Carling, J. 2002. Migration in the age of involuntary immobility: Theoretical reflections and Cape Verdean experiences. Journal of Ethnic and Migration Studies 28 (1):5-42.

Carney, J. 1993. Converting the Wetlands, Engendering the Environment: The Intersection of Gender with Agrarian Change in the Gambia. Economic Geography 69 (4):329-348.

Carney, J. A. 2009. Black Rice: The African Origins of Rice Cultivation in the Americas. Harvard University Press.

Castles, S., H. de Haas, and M. J. Miller. 2013. The Age of Migration, Fifth Edition:

International Population Movements in the Modern World Fifth edition. New York: The Guilford Press.

Champion, T., and T. Fielding. 1992. Migration Processes and Patterns: Research Progress and Prospects. https://www.amazon.com/Migration-Processes-Patterns-Research-

Prospects/dp/0471945048 (last accessed 19 November 2018).

Chant, S. 1992. Gender and Migration in Developing Countries. John Wiley \& Sons, Incorporated.

Chant, S., and A. Evans. 2010. Looking for the one(s): young love and urban poverty in The Gambia. Environment and Urbanization 22 (2):353-369.

Corbin, J. M., and A. Strauss. 1990. Grounded theory research: Procedures, canons, and evaluative criteria. Qualitative Sociology 13 (1):3-21.

Courtright, J. 2018. Gambia's diaspora helped oust a dictator. Now they're asking: What's next? Christian Science Monitor. https://www.csmonitor.com/World/Africa/2018/0129/Gambia-sdiaspora-helped-oust-a-dictator.-Now-they-re-asking-What-s-next (last accessed 25 March 2020).

Crenshaw, K. 1989. Demarginalizing the Intersection of Race and Sex: A Black Feminist Critique of Antidiscrimination Doctrine, Feminist Theory and Antiracist Politics. University of Chicago Legal Forum (1). https://chicagounbound.uchicago.edu/uclf/vol1989/iss1/8. 1991. Mapping the Margins: Intersectionality, Identity Politics, and Violence against Women of Color. Stanford Law Review 43:1241.

Cresswell, T. 1997. Weeds, Plagues, and Bodily Secretions: A Geographical Interpretation of Metaphors of Displacement. Annals of the Association of American Geographers 87 (2):330345.

Cresswell, T. 2006. On the Move: Mobility in the Modern Western World. Taylor \& Francis.

—. 2012. Mobilities II: Still. Progress in Human Geography 36 (5):645-653.

Creswell, J. W. 1998. Qualitative inquiry and research design: Choosing among five traditions. Thousand Oaks, CA: SAGE. 
Creswell, J. W., and J. D. Creswell. 2018. Research Design: Qualitative, Quantitative, and Mixed Methods Approaches Fifth edition. Los Angeles: SAGE Publications, Inc.

van Dijk, T. A. 2018. Discourse and Migration. In Qualitative Research in European Migration Studies, IMISCOE Research Series., eds. R. Zapata-Barrero and E. Yalaz, 227-245. Cham: Springer International Publishing http://link.springer.com/10.1007/978-3-319-76861-8 (last accessed 1 May 2020).

Domosh, M., and J. Seager. 2001. Putting Women in Place: Feminist Geographers Make Sense of the World 1 edition. New York: The Guilford Press.

DW. 2019. How can Gambian returnee migrants be best re-integrated into their societies? | Street debate. https://www.youtube.com/watch?v=O0sQzP3k26s.

Ellis, M., and R. Wright. 1998. The Balkanization Metaphor in the Analysis of U.S. Immigration. Annals of the Association of American Geographers 88 (4):686-698.

Faces2Hearts. 2019. Faces2Hearts in THE GAMBIA: Tekki Fii - Make It Here (In The Gambia). https://www.youtube.com/watch?v=tTinl6TBkbs (last accessed 30 April 2020).

Faist, T. 2009. Making and remaking the transnational: Of boundaries, social spaces and social mechanisms. Spectrum: Journal of Global Studies 1 (2):67-89.

Fedyuk, O., and V. Zentai. 2018. The Interview in Migration Studies: A step towards a dialogue and knowledge co-production? In Qualitative Research in European Migration Studies, IMISCOE Research Series., eds. R. Zapata-Barrero and E. Yalaz, 171-188. Cham: Springer International Publishing http://link.springer.com/10.1007/978-3-319-76861-8 (last accessed 1 May 2020).

Flick, U. 1998. Sampling Strategies. In An Introduction to Qualitative Research, 62-73. Thousand Oaks, CA: SAGE Publications Ltd.

Flippen, C. A. 2014. Intersectionality at Work: Determinants of Labor Supply among Immigrant Latinas. Gender \& Society 28 (3):404-434.

Frowd, P. M. 2018. Developmental borderwork and the International Organization for Migration. Journal of Ethnic and Migration Studies 44 (10):1656-1672.

Gaibazzi, P. 2011. Home as Transit: Would-Be Migrants and Immobility in Gambia. In The Challenge of the Threshold: Border Closures and Migration Movements in Africa. Lanham, MD, UNITED STATES: Lexington Books http://ebookcentral.proquest.com/lib/wvu/detail.action?docID=862639 (last accessed 31 October 2018).

- 2015. Bush Bound: Young Men and Rural Permanence in Migrant West Africa. New York, NY, UNITED STATES: Berghahn Books, Incorporated.

http://ebookcentral.proquest.com/lib/wvu/detail.action?docID=4000013 (last accessed 31 October 2018). 
George, S. 2005. When Women Come First: Gender and Class in Transnational Migration. University of California Press.

Gibbons-Neff, T., H. Cooper, and T. Kalifa. 2018. Deployed Inside the United States: The Military Waits for the Migrant Caravan. The New York Times 10 November.

https://www.nytimes.com/2018/11/10/us/deployed-inside-the-united-states-the-military-waitsfor-the-migrant-caravan.html (last accessed 26 April 2020).

Gilroy, P. 1993. The Black Atlantic: Modernity and Double-Consciousness Reissue edition. Cambridge, Mass: Harvard University Press.

- 2016. Between Camps: Nations, Cultures and the Allure of Race 1 edition. Routledge.

Glaser, B., and A. Strauss. 1967. The discovery of grounded theory. 1967. Weidenfield \& Nicolson, London :1-19.

Gorman, C. S. 2017. Redefining refugees: Interpretive control and the bordering work of legal categorization in U.S. asylum law. Political Geography 58:36-45.

- 2019. Defined by the Flood: Alarmism and the Legal Thresholds of U.S. Political Asylum. Geopolitics.

Gössling, S., and J. H. Nilsson. 2010. Frequent Flyer Programmes and the Reproduction of Aeromobility. Environment and Planning A: Economy and Space 42 (1):241-252.

Gregory, D., R. Johnston, G. Pratt, M. Watts, and S. Whatmore eds. 2009. The Dictionary of Human Geography 5 edition. Malden, MA: Wiley-Blackwell.

Grigg, D. B. 1977. E. G. Ravenstein and the "laws of migration." Journal of Historical Geography 3 (1):41-54.

Haas, H. de. 2007. Turning the Tide? Why Development Will Not Stop Migration. Development and Change 38 (5):819-841.

- 2008. The Myth of Invasion: the inconvenient realities of African migration to Europe. Third World Quarterly 29 (7):1305-1322.

Halfacree, K., and P. Boyle. 1993. The challenge facing migration research: the case for a biographical approach. Progress in Human Geography 17 (3):333-348.

Hannam, K., G. Butler, and C. M. Paris. 2014. Developments and key issues in tourism mobilities. Annals of Tourism Research 44:171-185.

Hannam, K., M. Sheller, and J. Urry. 2006. Editorial: Mobilities, Immobilities and Moorings. Mobilities 1 (1):1-22.

Haraway, D. 1988. Situated Knowledges: The Science Question in Feminism and the Privilege of Partial Perspective. Feminist Studies 14 (3):575-599. 
Harper, R. A., and H. Zubida. 2016. "Here One Moment... and Gone the Next?" Remittance as a Social Visibility Tool. Sociological Inquiry 86 (3):324-347.

Harvey, D. 2007. The Limits to Capital Updated edition. London; New York: Verso.

Heberle, R. 1938. The Causes of Rural-Urban Migration a Survey of German Theories. American Journal of Sociology 43 (6):932-950.

Heller, M., A. Jaworski, and C. Thurlow. 2014. Introduction: Sociolinguistics and tourism mobilities, markets, multilingualism. Journal of Sociolinguistics 18 (4):425-458.

Houtum, H. V., and T. V. Naerssen. 2002. Bordering, Ordering and Othering. Tijdschrift voor economische en sociale geografie 93 (2):125-136.

Hyndman, J. 2005. Migration wars: refuge or refusal? Geoforum 36 (1):3-6.

Hyndman, J., and A. Mountz. 2008. Another Brick in the Wall? Neo-Refoulement and the Externalization of Asylum by Australia and Europe1. Government and Opposition 43 (2):249269.

International Trade Centre. 2019. Tekki Fii insights: solar panel installation. The Gambia. https://www.facebook.com/watch/?v=346151932685749 (last accessed 30 April 2020).

IOM. 2015. Assisted Voluntary Return and Reintegration. International Organization for Migration. https://www.iom.int/assisted-voluntary-return-and-reintegration (last accessed 15 April 2020).

- 2019. IOM Voluntary Humanitarian Return Assistance to Migrants Continues Amid Conflict in Tripoli. International Organization for Migration. https://www.iom.int/news/iomvoluntary-humanitarian-return-assistance-migrants-continues-amid-conflict-tripoli (last accessed 6 December 2019).

Isaakyan, I., and A. Triandafyllidou. 2017. "Sending so much more than money": Social Remittances, Transnational Mobility and the Re-positioning of the Migrant. Ethnic and Racial Studies 40 (15):17.

Jackson, P., P. Crang, and C. Dwyer. 2004. Transnational spaces. Routledge London.

Janko, S. S. 2012. Youth in the Gambia stay put thanks to government farming initiative. The Guardian 7 September. https://www.theguardian.com/global-development/2012/sep/07/youthgambia-government-farming-initiative (last accessed 3 November 2018).

Jeffang, K. 2019. Chained, Bundled into the Plane and Restrained: Gambian Deportees Narrate Ordeal. The Chronicle Gambia. https://www.chronicle.gm/chained-bundled-into-the-plane-andrestrained-gambian-deportees-narrate-ordeal/ (last accessed 27 March 2020).

Jensen, O. B. 2009. Flows of Meaning, Cultures of Movements - Urban Mobility as Meaningful Everyday Life Practice. Mobilities 4 (1):139-158. 
Jones, R. 2016. Violent Borders: Refugees and the Right to Move. Verso Books.

Jonker, G., and V. Amiraux. 2006. Politics of Visibility: Young Muslims in European Public Spaces. transcript Verlag. https://www.oapen.org/search?identifier=1007619 (last accessed 26 February 2020).

Kabbanji, L. 2013. Towards a Global Agenda on Migration and Development? Evidence from Senegal. Population, Space and Place 19 (4):415-429.

Kebbeh, C. O. 2013. The Gambia: Migration in Africa's "Smiling Coast." migrationpolicy.org. https://www.migrationpolicy.org/article/gambia-migration-africas-smiling-coast (last accessed 31 October 2018).

- 2014. A Profile of African Immigrants in the US Labour Market. Rochester, NY: Social Science Research Network. https://papers.ssrn.com/abstract=2530480 (last accessed 11 April 2020).

King, R. 2018. Context-based qualitative research and multi-sited migration studies in Europe. In Qualitative Research in European Migration Studies, IMISCOE Research Series., eds. R. Zapata-Barrero and E. Yalaz, 35-56. Cham: Springer International Publishing http://link.springer.com/10.1007/978-3-319-76861-8 (last accessed 1 May 2020).

Kühnemund, J. 2018. Topographies of "Borderland Schengen": Documental Images of Undocumented Migration in European Borderlands. Bielefeld: transcript Verlag.

Kusow, AbdiM. 2006. Migration and Racial Formations Among Somali Immigrants in North America. Journal of Ethnic \& Migration Studies 32 (3):533-551.

Lacroix, T., P. Levitt, and I. Vari-Lavoisier. 2016. Social remittances and the changing transnational political landscape. Comparative Migration Studies 4 (1):16.

Lahiri, S. 2003. Performing identity: colonial migrants, passing and mimicry between the wars. cultural geographies 10 (4):408-423.

Langevang, T. 2008. 'We are managing!' Uncertain paths to respectable adulthoods in Accra, Ghana. Geoforum 39 (6):2039-2047.

Lavenex, S., and R. Kunz. 2008. The Migration-Development Nexus in EU External Relations. Journal of European Integration 30 (3):439-457.

Lee, M., N. Madyun, B. O. Lam, and M. Jumale. 2014. School Contexts and "Acting White"Peer Networks of Somali Immigrant Youths in an Afrocentric Charter School. Schools 11 (1):122155 .

Levitt, P. 1998. Social Remittances: Migration Driven Local-Level Forms of Cultural Diffusion. International Migration Review 32 (4):926-948. 
Ley, D. 2004. Transnational spaces and everyday lives. Transactions of the Institute of British Geographers 29 (2):151-164.

Linke, U. 2018. Fortress Europe: Globalization, Militarization and the Policing of Interior Borderlands. TOPIA: Canadian Journal of Cultural Studies.

https://www.utpjournals.press/doi/abs/10.3138/topia.23-24.100 (last accessed 30 October 2019).

Mahieu, R. 2019. 'We're not coming from Mars; we know how things work in Morocco!' How diasporic Moroccan youth resists political socialisation in state-led homeland tours. Journal of Ethnic and Migration Studies 45 (4):674-691.

Mahler, S. J., M. Chaudhuri, and V. Patil. 2015. Scaling Intersectionality: Advancing Feminist Analysis of Transnational Families. Sex Roles 73 (3-4):100-112.

Mamadouh, V. 2012. The Scaling of the 'Invasion': A Geopolitics of Immigration Narratives in France and The Netherlands. Geopolitics 17 (2):377-401.

Massey, D. 1993. "Power Geometry and a Progressive Sense of Place" - Chapter. In Mapping the futures: local cultures, global change, ed. J. Bird. London: Routledge.

Massey, D. S., L. Goldring, and J. Durand. 1994. Continuities in Transnational Migration: An Analysis of Nineteen Mexican Communities. American Journal of Sociology 99 (6):1492-1533.

Mckenzie, S., and C. Menjívar. 2011. The meanings of migration, remittances and gifts: views of Honduran women who stay. Global Networks 11 (1):63-81.

McKittrick, K. 2006. Demonic Grounds: Black Women And The Cartographies Of Struggle First edition edition. Minneapolis: Univ Of Minnesota Press.

Merriam, S. B. 1991. Case study research in education: A qualitative approach 1 edition. Jossey-Bass.

Morokvasic, M. 1984. Birds of Passage are also Women... The International Migration Review 18 (4):886-907.

Mountz, A. 2009. Border. In Key Concepts in Political Geography, eds. C. Gallaher, C. T. Dahlman, M. Gilmartin, A. Mountz, and P. Shirlow, 198-209. London; Los Angeles: SAGE Publications Ltd.

NAGEL, C. 2016. Southern Hospitality?: Islamophobia and the Politicization of Refugees in South Carolina during the 2016 Election Season. Southeastern Geographer 56 (3):283-290.

Nembhard, J. G. 2014. Collective Courage: A History of African American Cooperative Economic Thought and Practice. Penn State Press.

Neumayer, E. 2005. Bogus Refugees? The Determinants of Asylum Migration to Western Europe. International Studies Quarterly 49 (3):389-410. 
Nyberg-Sørensen, N., N. V. Hear, and P. Engberg-Pedersen. 2002. The Migration-Development Nexus Evidence and Policy Options State-of-the-Art Overview. International Migration 40 (5):3-47.

Palafox, J. 2000. Opening Up Borderland Studies: A Review of U.S.-Mexico Border Militarization Discourse. Social Justice 27 (3 (81)):56-72.

Pallister-Wilkins, P. 2015. The humanitarian policing of "Our Sea." https://dare.uva.nl/search?identifier=3c708fba-f685-4a8a-a15c-77c8015e597a (last accessed 18 November 2019).

Pallister-Wilkins, P. 2016. Humanitarian Borderwork. In Border politics: defining spaces of governance and forms of transgressions, eds. C. Günay and N. Witjes, 84-103. New York, NY: Springer Berlin Heidelberg.

Park, J. 2015. Europe's Migration Crisis. Council on Foreign Relations. https://www.cfr.org/backgrounder/europes-migration-crisis (last accessed 18 March 2019).

Pécoud, A. 2018. What do we know about the International Organization for Migration? Journal of Ethnic and Migration Studies 44 (10):1621-1638.

Peshkin, A. 1988. In search of subjectivity—one's own. Educational Researcher 17 (7):17-21.

Phizacklea, A. ed. 1983. One Way Ticket: Migration and Female Labour First Edition edition. London ; Boston: Routledge Kegan \& Paul.

Pratt, G. 1999. From Registered Nurse to Registered Nanny: Discursive Geographies of Filipina Domestic Workers in Vancouver, B.C. Economic Geography 75 (3):215-236.

-2012. Families Apart: Migrant Mothers and the Conflicts of Labor and Love 1 edition. Minneapolis: Univ Of Minnesota Press.

Prothmann, S. 2018. Migration, masculinity and social class: Insights from Pikine, Senegal. International Migration 56 (4):96-108.

Pulido, L. 2007. A Day Without Immigrants: The Racial and Class Politics of Immigrant Exclusion. Antipode 39 (1):1-7.

Römhild, R. 2016. Reflexive Mediterranisation: Mobilities, Economies, and the Cultural Remittance of Imaginaries. In Migration and Social Remittances in a Global Europe, Europe in a Global Context., eds. M. Nowicka and V. Šerbedžija, 27-47. London: Palgrave Macmillan UK https://doi.org/10.1057/978-1-137-60126-1_2 (last accessed 6 March 2020).

Salazar, N. B. 2011. The Power of Imagination in Transnational Mobilities. Identities 18 (6):576-598.

Samuel, H., and N. Squires. 2017. "Millions of Africans" will flood Europe unless it acts now, warns European chief, as Paris evacuates huge migrant camp. The Telegraph 7 July. 
https://www.telegraph.co.uk/news/2017/07/07/millions-africans-will-flood-europe-unless-actsnow-warns-european/ (last accessed 27 March 2019).

Scheyvens, R. 2007. Poor cousins no more: valuing the development potential of domestic and diaspora tourism. Progress in Development Studies 7 (4):307-325.

Schiller, N. G., L. Basch, and C. S. Blanc. 1995. From Immigrant to Transmigrant: Theorizing Transnational Migration. Anthropological Quarterly 68 (1):48.

Schroeder, R. A. 1999. Shady Practices: Agroforestry and Gender Politics in The Gambia. University of California Press.

Schurr, C. 2019. Multiple mobilities in Mexico's fertility industry. Mobilities 14 (1):103-119.

Shabazz, R. 2015. Spatializing Blackness: Architectures of Confinement and Black Masculinity in Chicago. University of Illinois Press.

Sieff, K. 2015. Tiny Gambia has a big export: Migrants desperate to reach Europe. Washington Post. http://www.washingtonpost.com/sf/world/2015/06/14/tiny-gambia-has-a-big-exportmigrants-desperate-to-reach-europe/ (last accessed 14 April 2020).

Siegler, M. 2018. Wisconsin father of two deported to west Africa. USA TODAY. https://www.usatoday.com/story/news/nation-now/2018/03/08/wisconsin-father-two-deportedwest-africa/409448002/ (last accessed 27 March 2019).

SIGambia. 2019. Clients | Startup Incubator Gambia. https://www.startupincubator.gm/clients/1 (last accessed 7 December 2019).

Silvey, R. 2006. Geographies of Gender and Migration: Spatializing Social Difference. International Migration Review 40 (1):64-81.

- 2007. Borders, Embodiment, and Mobility: Feminist Migration Studies in Geography. In A Companion to Feminist Geography, eds. L. Nelson and J. Seager, 138-149. Oxford, UK: Blackwell Publishing Ltd http://doi.wiley.com/10.1002/9780470996898.ch10 (last accessed 19 February 2019).

Sinatti, G. 2014. 11 Masculinities and Intersectionality in Migration: Transnational Wolof Migrants Negotiating Manhood and Gendered Family Roles. In Migration, Gender and Social Justice: Perspectives on Human Insecurity, Hexagon Series on Human and Environmental Security and Peace., eds. T.-D. Truong, D. Gasper, J. Handmaker, and S. I. Bergh, 215-226. Berlin, Heidelberg: Springer Berlin Heidelberg https://doi.org/10.1007/978-3-642-28012-2_11 (last accessed 21 April 2019).

Smith, M. P., and L. E. Guarnizo. 1998. Transnationalism from Below. Transaction Publishers.

Steusse, A. 2016. Scratching Out a Living. California: UC Press.

https://www.ucpress.edu/book/9780520287211/scratching-out-a-living (last accessed 27

February 2020). 
Taylor, E. J. 1999. The New Economics of Labour Migration and the Role of Remittances in the Migration Process. International Migration 37 (1):63-88.

Vertovec, S. 2001. Transnationalism and identity. Torpoint : Taylor \& Francis,.

Vertovec, Steven. 1999. Conceiving and Researching Transnationalism. Ethnic and Racial Studies.

de Villiers, M., and S. Hirtle. 1997. Into Africa: A Journey Through the Ancient Empires First Edition edition. Toronto: Key Porter Books.

Walters, W. 2010. Foucault and Frontiers: Notes on the Birth of the Humanitarian Border. In Governmentality, eds. U. Bröcking, S. Krassman, and T. Lemke. https://www.taylorfrancis.com/ (last accessed 19 November 2019).

Washington Post. 2019. Denied asylum, but not deported, migrants in Europe live in limbo. Washington Post. https://www.washingtonpost.com/world/europe/denied-asylum-but-notdeported-migrants-in-europe-live-in-limbo/2019/08/07/1b9f3082-a4ad-11e9-a767-

d7ab84aef3e9_story.html (last accessed 1 May 2020).

White, M. M. 2018. Freedom Farmers: Agricultural Resistance and the Black Freedom Movement. UNC Press Books.

Wimmer, A., and N. G. Schiller. 2002. Methodological nationalism and beyond: nation-state building, migration and the social sciences. Global Networks 2 (4):301-334.

Winant, H., and M. Omi. 1984. Racial Formations. In Race, Class, and Gender in the United States, ed. P. S. Rothenberg, 13-22. Macmillan.

Wong, M. 2006. The Gendered Politics of Remittances in Ghanaian Transnational Families. Economic Geography 82 (4):355-381.

Wright, D. R. 1985. Beyond Migration and Conquest: Oral Traditions and Mandinka Ethnicity in Senegambia*. History in Africa 12:335-348.

- 2010. The World and a Very Small Place in Africa: A History of Globalization in Niumi, the Gambia 3 edition. Routledge.

Wright, M. 2013. Disposable Women and Other Myths of Global Capitalism. Routledge.

YEP. 2017. Tekki Fii Programme at a glance - Tool | YEP. https://www.yep.gm/tool/tekki-fiiprogramme-glance (last accessed 6 December 2019).

Zapata-Barrero, R., and E. Yalaz eds. 2018. Qualitative Research in European Migration Studies. Cham: Springer International Publishing. http://link.springer.com/10.1007/978-3-31976861-8 (last accessed 1 May 2020). 
Zelinsky, W. 1971. The Hypothesis of the Mobility Transition. Geographical Review 61 (2):219-249. 